\title{
COVID-19 and Change
}

\author{
Miguel Goede \\ Anton de Kom University of Suriname \\ University of Governance
}

The purpose of this article is to identify and describe the changes that have taken place or are taking place throughout our societal structures as a consequence of the COVID-19 pandemic crisis. It draws from published articles that have reported on the changes in many different areas of research to assemble a picture of the overall impact. It starts with the origin of the pandemic and how the different countries responded. To continue with the changes in many areas. It might change our human species, the world order, globalization, the capitalistic system, governance, civil and human rights, climate and nature, the economy, the influence of science, the food production, the Future of Work, Pensions and Universal Basic Income, the spread of cryptocurrency, the changes in Health Care, family structures and living, the way we learn, travel, religion and mass gatherings. The article discusses the coming out of the lockdown and the scenarios after coming out of the lockdown and ends with the conclusions.

Keywords: COVID-19, world order, globalization, capitalism, neoliberalism, governance, civil right, climate change, economy, science, food security, future of work, cryptocurrency, healthcare, family structures, learning, travel, mass gathering

\section{INTRODUCTION}

This article identifies and describes the changes that have taken place or are taking place throughout our societal structures as a consequence of the COVID-19 pandemic crisis. The article draws from published articles and papers on the changes caused by the COVID-19 pandemic in many different research areas to assemble a larger picture of the overall impact.

The onset and evolution of the COVID-19 pandemic has revealed systemic vulnerabilities in a wide variety of areas, from the world order and the economy to the delivery of health care and how families function. Given the size and magnitude of the disruptions, returning to pre-COVID-19 conditions is not an alternative. The crisis has accelerated many trends while muting or slowing others. It has enhanced the shift of the centrum of power from the West to the East. Many countries have begun to think locally again, especially regarding supply chains and food security. The role of government has increased on a range of fronts. Digitalization has increased as the concept of 'social distancing' and functioning remotely has become the new normal.

Over a relatively short period, since the pandemic began, many studies on the impact of the pandemic have been published, though they have been largely focused on specific topics. By contrast, this research aimed to compile these various impacts to understand the bigger picture better as these dramatic changes 
are interwoven into our daily lives. The pandemic has and will continue to change the world in many areas and many ways.

Many terms have been used to refer to the coronavirus pandemic, including coronavirus, COVID-19, SARS-COV-2, and novel corona. Corona means crown in Spanish. Ironically the last pandemic was the Spanish Flu, which occurred 100 years ago and lasted from 1917 to 1920 . The Spanish Flu actually originated in the United States, not Spain. The Spanish press was the only one reporting extensively on the pandemic as press corps in the other countries were focused on WWI and did not want to report on the illness to avoid demoralizing the troops. For some, coronavirus metaphorically represents the removal of the crown of globalization and capitalism as we know them (Coronacrisis kondigt het einde van de globalisering aan, 2020; COVID-19 pandemic highlights' need for more cooperation between countries, not less': PM Lee, 2020). (Coronacrisis kondigt het einde van de globalisering aan, 2020; COVID-19 pandemic highlights 'need for more cooperation between countries, not less': PM Lee, 2020).

Thirty years before the Spanish Flu, there was the Russian Flu of 1890. This flu is less known, but some experts have suggested that it has similarities with the coronavirus. (Keulemans, 2020).

After the coronavirus was detected in Wuhan, China, and killed more than 3,000 people, it very rapidly became a pandemic forcing many countries to lockdown their citizens, which is to say they were required to stay in their homes, usually due to specific risks to themselves and/or to others if they were to move freely. This number is contested. Some say that the number of people who died is in the order of 40,000 people. Others estimate that based on the number of cellphone numbers that no longer operate, that the number of deaths is in the order of one million people. Mid-April 2020, China stated that the number was double the initially published number. On the 19th of March, Wuhan reported that zero local infected on one day. Life was returning to normal, while experts warn for a possible second wave and the second wave came in late April 2020.

Corona is reminiscent of the story in the Bible about the Tower of Babel. This time, humans constructed the tower digitally. We were already talking about Homo Deus. Corona taught us that (medical) science is not God. It forced us behind our own borders and behind our own doors, like the plagues in Egypt that are described in the Bible.

It is time to press the reset button, and the clock is not at five minutes to twelve, but it is five minutes past twelve. A new vision and implementation plan are needed. In this new reality, dreamers must become doers, and doers must dream too. The corona pandemic will reset the world (Mascini, 2020). However, it is notable that this reset is not just a result of COVID-19 but also the killing of George Floyd by Minneapolis police officers on the $25^{\text {th }}$ of May 25, 2020.

The fundamental question addressed in this chapter is which areas are most affected and how will the COVID-19 pandemic change the world. Many aspects were considered to answer this question, including the theories on the origins of the virus, the pandemic's causes, how different countries and leaders responded, how these changes will occur, and the possible outcomes.

This chapter addresses the period from December 2019 to July 2020, though the pandemic is far from over. It was updated in February 2021.

\section{THE ORIGINS OF THE PANDEMIC}

Before examining the consequences of the crisis, it is important to better understand the origins of the corona. The first theory was that it originated from human interaction with a wild animal, which could have been a bat, a pangolin (Briggs, 2020), (Briggs, 2020), or a snake. Several other wild animals were also mentioned as alternative culprits, and a combination of two animals has been suggested. Sources have posited that it started at a wet market in Wuhan. Later, Chinese researchers revealed that this wet market acted as a super spreader, though it was reportedly not the place where the pandemic originated (Quekel, 2020).

Sometime in mid to late April 2020 came the theory that the virus might have been circulating as early as September 2019, and the start of the pandemic might not be related to Wuhan (Osborne, 2020). In June 
2020, research showed that the virus that was detected in December was already present in Italy (Kelland, 2020).

There is also a theory that the virus has existed in humans for many years, but it mutated into its current form (Bowler, 2020), transformed, and became what it currently is (Bowler, 2020). In December 2020, the virus started to mutate. The most notorious mutation was the British, but there was also the one of South Africa, Brazil, and Japan, to name a few.

Fifteen years ago, in a journal, the Jehovah's Witness sect foresaw the epidemic in some detail, mentioning China as the place it would start (Jehovah's Witness predicted coronavirus 15 years ago, 2020). There are references to the book by Dean Koontz from 1981, The Eyes of Darkness. Others refer to the TV show The Simpson from 1993. There are also similarities with the movie Outbreak, made in 1995. In all cases, the corona is presented as a human-made and biological weapon.

Other theories have been classified as conspiracy theories. According to the source Telesur, the political scientist Chomsky stated that the coronavirus is a biological weapon with the characteristics to kill the elderly, and young people are not much impacted. The coronavirus was planted by the United States in Wuhan just before the Chinese New Year to sabotage the Chinese economy. Iran, Italy, and Western Europe were also targeted, and the United Kingdom as a faithful ally was to be spared. The plan was to destabilize China for a short period so the United States could strengthen its economic and political position. The plan worked, but the virus entered the United States (Telesur, 2020). There are other sources presenting the same story (La verdad oculta del coronavirus, 2020). (La verdad oculta del coronavirus, 2020). This theory has yet to be confirmed, and other investigations have refuted these claims (Stellino, 2020).

Another theory claims it is a means to control the size of the population in China (Is COVID-19 A Bioweapon? Five Conspiracy Theories Around Coronavirus That Will Shock You, 2020; NOS, 2020). (Is COVID-19 A Bioweapon? Five Conspiracy Theories Around Coronavirus That Will Shock You, 2020; NOS, 2020).

Others have suggested that the corona pandemic was a cover-up designed to distract from the issues associated with the large-scale deployment of 5G technology in Wuhan.

Another theory is that it was created by China to impact the financial markets. During the crisis, stock prices dropped, and shares were purchased by the Chinese. In this way, the Chinese increased their global dominance. In mid-April 2020, President Trump made this type of accusation and even stating that China could face the consequences (Trump warns China could face 'consequences' over COVID-19 pandemic, 2020). (Trump warns China could face 'consequences' over COVID-19 pandemic, 2020). In May 2020, the United States claimed that its intelligence community had obtained the necessary conclusive proof to back up its accusations (Fabian, Jacobs, \& Marlow, 2020). (Fabian, Jacobs, \& Marlow, 2020). A few days later, this was contradicted by experts assisting the president. Dr. Fauci declared that it is not likely that the virus was developed in the lab in Wuhan, and the most probable explanation remains the jump of the virus from an animal to a human (Villarreal, 2020). (Villarreal, 2020).

Others accused the World Health Organization (WHO) of having close ties with Big Pharma. These accusations were denied by the other side (Director of Wuhan lab denies COVID-19 link, 2020). (Director of Wuhan lab denies COVID-19 link, 2020).

Another theory is that the corona crisis was created so that people would agree to be vaccinated, allowing for the implantation of a chip in all humans, which would allow the global elite and the deep state to control all of humanity. This theory is often linked to the theory regarding Bill Gates. Mr. Gates discussed or predicted a pandemic in 2005. In 2019, Gates was part of a pandemic simulation organized by the World Economic Forum. Others also mention the relationship between the foundation of Gates and Big Pharma. Perhaps even more suspicious, Mr. Gates and a dozen CEOs resigned from their corporate positions just before the crisis. On March 13, 2020, Gates left after 20 years as Chairman of the Board of Microsoft. Two Senators in the United States sold stocks after discovering the crisis was in its early stages. Like Jeff Bezos, some wealthy individuals also sold shares of their own company at an opportune time (Neate, 2020). The super-rich made billions in the first three weeks of the pandemic (America's Super-Rich See Their Wealth Rise by $\$ 282$ Billion in Three Weeks of Pandemic, 2020). (America's Super-Rich See Their Wealth Rise by $\$ 282$ Billion in Three Weeks of Pandemic, 2020). Some consider all these coincidences suspicious. 
To add to the theory of elite intervention, people point out that such a scenario, a pandemic described in a report of the Rockefeller Foundation, was so close to one of the scenarios (The Rockefeller Foundation, 2010), which led to the use of the term plandemic.

In February 2021, the WHO send a mission to Wuhan to investigate the origin. The mission had some difficulty getting the collaboration of the Chinese government. The wet market hypothesis could not be confirmed.

\section{THE CAUSES OF THE CRISIS}

The very likely truth is that humans have pushed wild animals out of their habitat, and humans live too close to them. This increases the risk of a virus jumping from animals to humans, where the virus continues to mutate (Stanford University, 2020; Carrington, 2020).

Some have indicated that inequality might also be one of the causes of the pandemic. Spinney refers to historical data to make this point (Spinney, 2020). Publications of the Rockstar French economist Piketty warned us that our current rate and type of development are not sustainable. In a recent interview, he pleads again for reform during the pandemic and to reform the system (Wallace-Wells, 2020).

The pandemic exposed inequality. In the United States and many other countries, the lines in front of food banks have become long (These Photos Show the Staggering Food Bank Lines Across America, 2020). The coronavirus crisis could double the number of people suffering from hunger. "About 265 million people around the world are forecast to be facing acute food insecurity by the end of this year, a doubling of the 130 million estimated to suffer severe food shortages last year." (Harvey F. , 2020).

Two pandemics exist, the one in the well-off countries and that in developing countries. Countries like Peru and Brazil were severely hit. There are at least two factors, including their weak healthcare system and the weak social safety nets (Letzing, 2020).

The coronavirus was not caused by inequality, but it exposed it, and it made the problem bigger (Fracalossi de Moraes, 2020). The Guardian report that during the pandemic, the wealthy friends of President Trump benefited from big government contracts (Stone, 2020).

Walter Scheidel asserted that catastrophe historically was the only thing that reduced inequality. "History cannot predict the future, but its message is as unpalatable as it is clear: With the rarest of exceptions, great reductions in inequality were only ever brought forth in sorrow." (Scheidel, 2017) Scheidel was talking about war, but it applies to pandemics as well. His point is definitely made by the widespread death associated with COVID-19 and the global aftershock of the death of the Afro-America George Floyd.

\section{HOW THE DIFFERENT COUNTRIES RESPONDED}

Another compelling issue is related to how different countries responded to the COVID-19 crisis. In general, two types of responses emerged: immediate and slow. The first includes the WHO approach, and the second is so-called herd immunity. Countries like Taiwan and Singapore, which reacted immediately, were initially able to contain the virus. (Harvey, et al., 2020; Wilson, 2020). Later, Singapore had to adjust because the virus kept spreading, and the citizens even had to go into lockdown. Some countries locked down timely, while others waited. Countries like Taiwan, Germany, and Korea tested intensively, and they registered a high number of corona cases but experienced a relatively low number of casualties (figure 1).

Technologically advanced countries used data to manage the crisis. Technologies like apps and artificial intelligence were used. Countries could learn from China, Italy, and Spain, who were the first to get hit. Portugal learned from neighboring Spain and imposed restrictive measures early (Smoltczyk, 2020). Populist governments like Brazil (Phillips, Brazil's Jair Bolsonaro says coronavirus crisis is a media trick, 2020), the United Kingdom (Sparrow, 2020), and the USA responded poorly. Brazil was hit relatively late by the virus but soon had one of the highest numbers of infections. On the $10^{\text {th }}$ of June 2020, the number of conditions increased again. 
It appears less democratic countries were able to respond swifter, though, according to Fukuyama, it has nothing to do with democracy. It is about state capacity, social trust, and leadership. Countries that had these three in place performed better than others (Fukuyama, 2020).

The case of the Netherlands is peculiar. The response was initially slow because they considered it like any other seasonal flu. Once containing the coronavirus was no longer an option, they implemented restrictive measures for the citizens appealing to good citizenship. A lockdown was not an option because it was about neutralizing the virus and saving the economy. The Dutch prime minister called it an intelligent lockdown. A part of the population did not obey the rules of social distancing. The Netherlands, the UK, and Sweden were the only ones to adopt the theory of herd immunity, a concept that has been associated with neoliberalism and survival of the fittest (Frey, 2020; Pepijn Brandon: Coronavirus and the "survival of the fittest" in the Netherlands, 2020).

While most European countries are preparing for lockdowns to stop the spread of the coronavirus, a few countries are opting for a different strategy: herd immunity. Instead of testing as many people as possible and implementing measures to increase social distancing, they want to purposefully let the virus spread among people who are at low risk so that a large part of the population becomes immune. This approach was first proposed by U.K.'s prime minister Boris Johnson, who refused to implement social distancing measures until a few days ago. While the U.K. officially distanced itself from this strategy, and Sweden continues to hold on to this approach, despite harsh criticism by the WHO. (Frey, 2020)

The Guardian reported that the UK placed wealth above health (Stewart, 2020), and Sweden persisted with herd immunity (Fund \& Hay, 2020). The country registered the highest number of deaths since 1993 in April 2020. In mid-May 2020, Sweden stopped admitting those above the age of 65 living in elderly care institutions to hospitals if they were suffering from the corona. By June 2020, some experts from Sweden admitted that they were wrong.

At the other extreme of the spectrum is El Salvador. President Nayib Bukele chose life first and the economy second. He declared that if he tried to save both as Italy did, he would end up losing both. There will be plenty of time to rebuild the economy after the crisis, he said (The speech that is moving the world. El Salvador president, Nayib Bukele on coronavirus pandemic, 2020).

The Caribbean SIDS had the luck that the coronavirus arrived late. The response was, in many cases, the immediate lockdown after the first cases were discovered. This was accomplished at the expense of the economy, which, in many cases, are tourism-based economies. Still, there were considerable differences. Countries like Curaçao and Suriname had extremely low numbers of cases. Aruba and Saint Maarten had a noticeable high number but were able to flatten the curve. After becoming corona-free, Surinam had an explosive second wave and had to move into lockdown at the beginning of June 2020. Cuba made headlines for sending hundreds of medical doctors to help treat patients in many countries around the globe, starting with Italy. Cuba later made headlines again because they were very successful in their efforts to contain the spread of the virus on their island. Some have even argued that Cuba deserves the Noble Price. African countries were having success with their approach, but this was much overlooked in the media (Hirsch, 2020). 


\section{FIGURE 1 \\ THE DANCE OF THE COUNTRIES UNTIL APRIL 2020}

\section{Chart 4: Approximation of Countries along the Hammer and the Dance Phases}

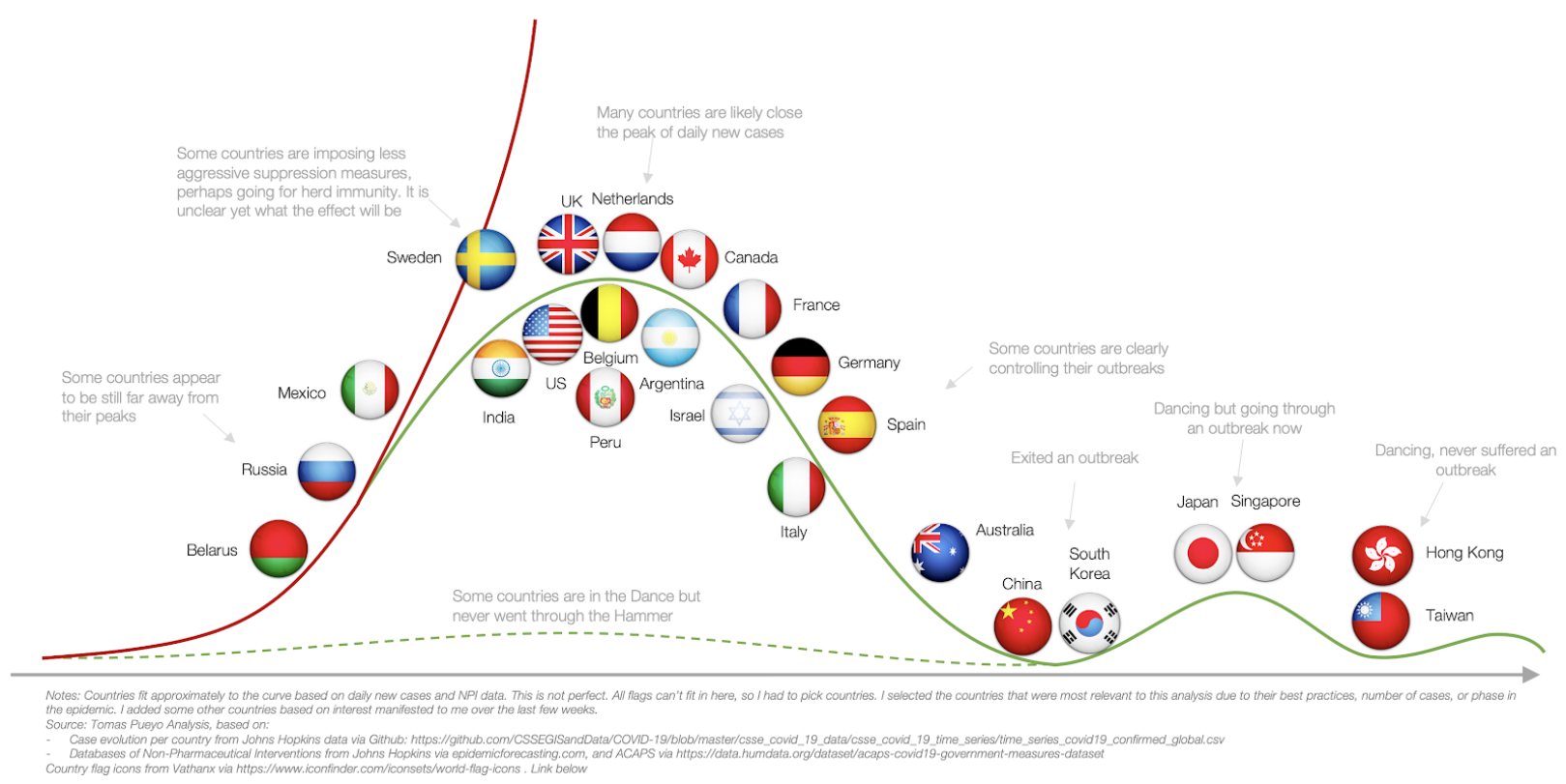

(Pueyo, Coronavirus: Learning How to Dance, 2020)

The other part of the response by governments, by sides the public health issues, was subsidizing companies to safe jobs and providing people with income and food packages by governments, besides the earlier mentioned restrictive measurements to safeguard public health.

Some governments exclude companies who practice tax evasion. By the beginning of June 2020 many countries, especially those who are very dependent upon tourism, were eager to open again to start the economic recovery and to start reducing poverty and mental health issues.

Regardless of the approach, many current leaders saw their approval rate initially rise (Zittende leiders profiteren van coronacrisis, 2020). Mahdawi, in The Guardian, indicated that countries with female leaders handled the crisis better. The countries that are mentioned include New Zealand, Taiwan, Germany, Iceland, Denmark, Norway, and Finland (Mahdawi, 2020; Wittenberg-Cox, 2020). Jacinda Ardern, the 39-year-old prime minister of New Zealand, is considered to be the best leader (Friedman, 2020). Claims are that women are more empathic and intervened earlier. This gives support to the argument that more females are needed in leadership roles (Hong Fincher, 2020).

The discussion was fueled by the fact that male leaders like Trump, Johnson (Toynbee, 2020), and Bolsonaro, according to many, failed foolishly. The Guardian reported that a year prior to the pandemic, the United States and the UK were ranked number one and two in readiness to deal with a pandemic. The structures were weakened within a year by decisions made by the respective leaders. It is telling that both Johnson and Bolsonaro got infected.

According to CNN, the following countries had the right response to the pandemic: Taiwan, Iceland, South Korea, and Germany (Dewan, Pettersson, \& Croker, 2020).

"To some, this will appear as a great and definitive triumph for democracy. To others, it will showcase the clear "benefits" of authoritarian rule" (John, Burn, Garrett, \& Haass, 2020). The United Nations secretary-general Antonio Guterres was not pleased with the response of the world community. He stated that there was some solidarity among countries but no uniform approach. He was not pleased by the fact that some countries ignored the advice of the WHO (UN says COVID-19 is 'wake-up call' for the world, 
2020). Soon after, German Chancellor Angela Merkel said the coronavirus pandemic would be overcome more quickly if the world works together to tackle it.

In the context of the global response, the Pope declared that humans are more important than the economy. He also said that we should divert weapons spending to research future pandemics (People more important than the economy, Pope says about COVID-19 crisis, 2020).

\section{CHANGES}

What are the consequences of the coronavirus crisis, regardless of how it started and how the countries responded? Coronavirus will change the world permanently, just like 9/11 and the financial crisis of 2008 . The crisis also creates opportunities associated with the flexible use of technology, less polarization, a new appreciation of outdoor life, and simple pleasures. Society, government, healthcare, the economy, our lifestyle, and more will change. Individualism has become a risk, but this paradox will emerge; the individual will be more online but more connected.

Many have made lists of changes that will take place. Before going to the lists of changes, we should have a look at the predictions by the World Economic Forum on the effect of the pandemic. It is notable that the concerns are primarily economic (Figure 2).

\section{FIGURE 2 \\ PREDICTED EFFECTS OF CORONAVIRUS ON THE WORLD. IMAGE: WEF}

FIGURE B.1

\section{Most likely fallout for the world}

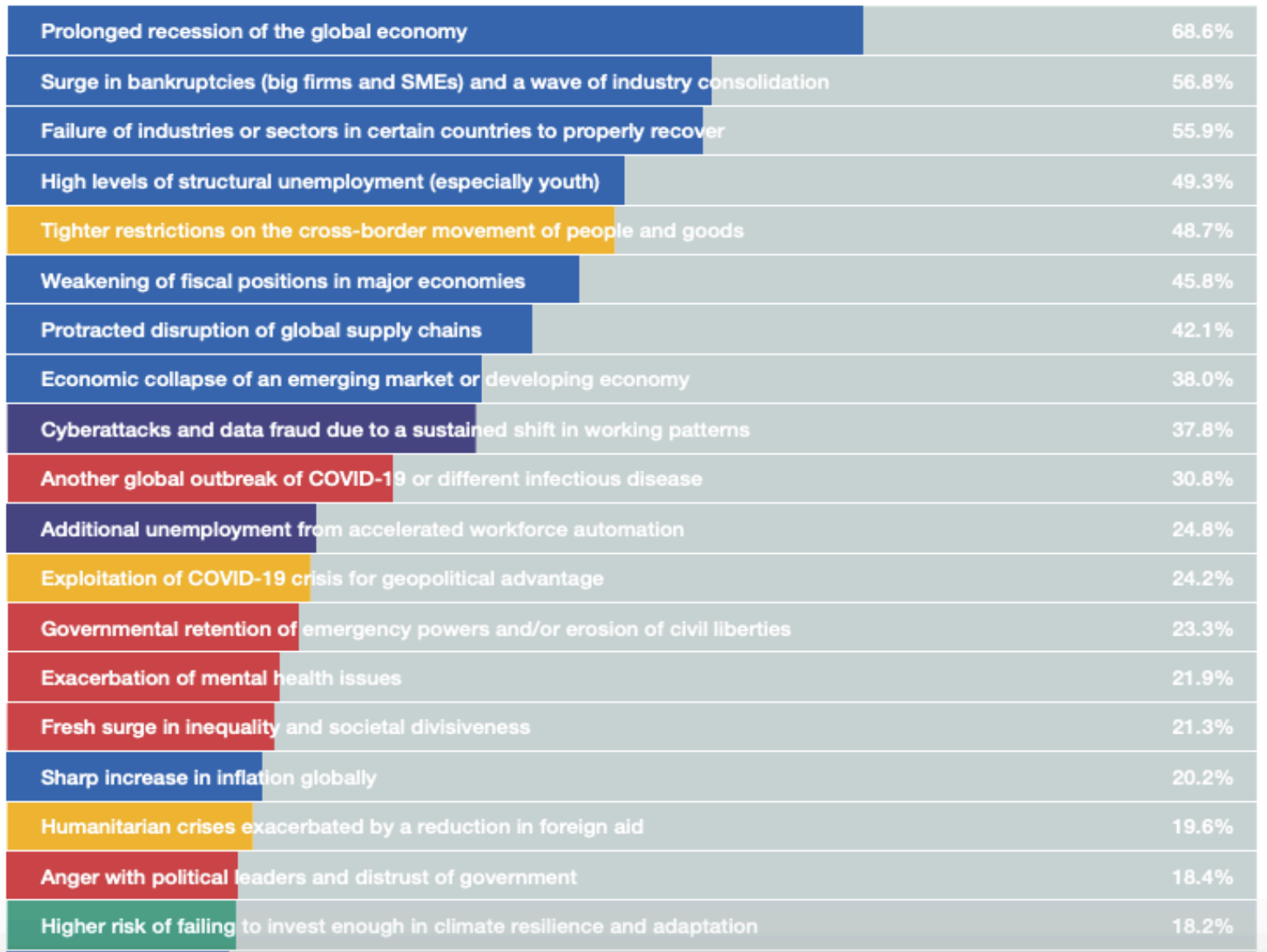

(Whiting, 2020) 
Prof. Yuval Noah Harari, the historian, philosopher, and the best-selling author, thinks that humankind will survive the corona pandemic, but it will trigger profound changes in healthcare, economy, politics, and culture. During the crisis, decisions that would have been taken after years of deliberation are being taken in a very short period of time. New technologies are emerging. Due to biometric technology, total surveillance is possible. People have a choice between privacy and health, and they will likely choose health. Corona was controlled by data and science. We must trust science again. It is about trust and not just science, but also public authorities and media. Global cooperation is important. It is the choice between national isolation or global solidarity. The sharing of information is key, as is the humanizing of crucial production lines and the pooling of medical personnel. Global collaboration is also vitally needed on the economic front. An example of the latter is a universal agreement regarding travel. Countries must trust that passengers arriving are healthy. The world needs leadership, but the United States has withdrawn from that role (Harari, 2020).

There will be a boom in virtual reality. E-learning and remote working will be the new norm. Patriotism will mean cultivating the health and life of the community rather than war with another community. There will be a decline in polarization. We will change course towards greater national solidarity. People will focus on the common enemy and be more open to change. There will be a revival of faith and science. We have learned that we are not God, but we have also learned that there are facts, and science is not just an opinion, and in fact, it matters. We have learned that we do not need to go to church to worship, and contemplative practices may gain popularity (Coronavirus Will Change the World Permanently. Here's How, 2020).

We are facing a crisis in our public health system combined with a pandemic, an economic crisis, a crisis of social reproduction and care, and a crisis in the valuation of human life in general. Even mainstream publications are now saying that it is unfathomable that postcoronavirus society will return to business as usual. However, unless we collectively develop a political discourse that is capable of responding to the crisis at each level, the real danger is that we will be forced into a society that retains all the worst features of what went on before. Moreover, this will only be intensified by unprecedented levels of austerity to pay for the losses that big business has suffered in the last couple of months by national governments wielding greatly enhanced powers, a far right preying on people's deepened fears and massively enhanced techniques for exploitation outside the workplace. (Pepijn Brandon: Coronavirus and the "survival of the fittest" in the Netherlands, 2020)

Few think we will go back to normal after the pandemic. We will not go back to normal because normal was the problem (Prashad, 2020). Some have suggested that the changes were already taking place, and the pandemic only accelerated them.

On August 11, 2020, Russia became the first country in the world to approve a vaccine. On the $8^{\text {th }}$ of December 2020, the UK was the first country to start the vaccination process using the Pfizer vaccine. Soon all countries that could afford the vaccines began as well. The effect on the pandemic was gradual.

Others like Shilling think that the corona crisis will lead to the following consequences: A long-term recession that will make us think of the 2010 s as a good economic period. It will take time for the financial markets to recover. The next consequence is the tendency of protectionism and the promotion of selfsufficiency. Face-to-face interaction will be reduced, and remote interaction will become more common. This will impact the travel and hotel industry. Consumers will consume less by postponing purchases. Fiscal stimulus will be magnified. Corona will influence the presidential elections in the United States in November 2020. The Democrats will come to power and install a medical care-for-all program, and changes in the tax code will be designed to redistribute income from the rich to the poor. This reduction in economic activity will cause crude oil prices to continue their drop (Shilling, 2020).

Bloomberg draws the following picture of the post-pandemic future. We will go through the most profound economic recession since the Great Depression. The whole financial system will have to be reset. There will be a reduction in the demand to hold dollars. The markets will continue to be very volatile. 
Countries will become more nationalistic. The Cold War between the United States and China will become more visible. China will shift further back to its Communist roots. The United States will converge towards China, not the other way around. People and businesses will consider how much exposure they want to have in the Chinese economy. Increasingly, free and low-cost access to digital services is going to be crucial to recovery. The entire e-commerce side of the business will continue to grow. All of this will become the new normal.

Employees will increasingly work at home. The way we work will be totally different. The way we learn and go to school will also be totally different. Business travel will diminish. There could be significant implications for gender diversity in the workplace. People will be permanently scarred by having lived through this pandemic. People will be more mindful of personal hygiene and closer scrutiny of cultural norms, such as handshakes and sources of food. People will literally understand that the action of one person can affect the globe. People will go out less and closer to home while spending more near their family. People will have to give up part of their privacy. It all changes how families communicate. Mental health will be part of the conversation. There will be a shift in care where artificial intelligence is the first point of care. People will start to think more broadly about problems like climate change, inequality, and other issues. We will have a deeper appreciation of the importance of government. And we will think more about sustainable globalization, international cooperation, integration, and economic growth (Bloomberg News, 2020).

Possible changes due to the pandemic, according to Walgien (2020) are:

1. Care for all

2. Our next vacation will be a staycation

3. Countries will isolate themselves more

4. We will evaluate globalization

5. Bullshit jobs will be eliminated where possible

6. We will value the doers

7. It is about We and not about I

8. Sustainability will gain momentum

9. We will implement the circular economy (Walgien, 2020).

Each of these anticipated changes are described in the following sections.

\section{Species}

The pandemic has revealed several paradoxes in society, the economy versus human life, global versus local, old versus young, rich versus poor, and white versus black. The consequence is that the coronavirus epidemic has or will change or reveal more about us as a species.

Covid-19 will change us as a species. We must respond not just as nations fighting an enemy but as a species fighting for survival. The virus will not wipe us out. But it is causing untold pain and loss, destabilizing global markets, and turning our daily lives into a surreal dreamscape. Our vulnerability and co-dependence are openly exposed. (Gleiser, 2020).

The pandemic has brought and will continue to bring the best and the worse out of people. People started to help the poor by starting or contributing to food banks. On the other hand, it triggered scapegoating, xenophobia, racism, and discrimination (Soudagar, 2020). In China, the Africans were blamed for spreading the virus. In Australia, racism against Chinese people is rising. In the United States, there was this senseless murder of the black man Mr. George Floyd. But in the end, optimism always has the upper hand.

\section{World Order}

In March 2020, the journal Foreign Policy summarized the pandemic's geopolitical consequences in the following manner. The corona crisis will lead to permanent shifts in political and economic power. The pandemic will strengthen the state and reinforce nationalism. Power will shift from the West to the East. 
The world will become more China-Centric. The world will remain a place of conflict. Previous plagues did not end great power rivalry or reign in a new era of global cooperation; neither will this one (John, Burn, Garrett, \& Haass, 2020; Fukuyama, 2020).

The leadership of the United States has eroded, as did the quality of its democracy. This became a massive crisis when police brutality against blacks became undeniable and systemic racism was exposed.

Observers expect China to increase its influence as a consequence of the loans they provided to countries and the economic collapse of these countries. China will make deals to that end. The United States seems to be in no position to offer these countries an alternative offer (Ibrahim, 2020; Dams, 2020). China will benefit from the effects of the pandemic on the financial market as well and try to take over European corporations (Eurocommissaris waarschuwt lidstaten voor bedrijfsovernames vanuit China, 20) and American companies. On the other hand, countries like Japan and the United States started to pull their companies out of China (Nakazawa, 2020). In the early stages of the pandemic, China increased its efforts to crush the protest in Hong Kong (Pinxteren, 2020).

Others have suggested that the post-pandemic world will not be dominated by China but by Asia, indicating India's role and countries like South Korea (Fukuyama, 2020). Ironically, China and India had their first border conflict that results in death, which had not occurred for 45 years. This might mark a turning point in their relationship (India and China have their first deadly clashes in 45 years, 2020).

Others state that leadership will come from Berlin. These two remarks can be combined that in the transition to a world order dominated by Asia, Berlin will fulfill a transitory leadership role. Ironically, it is Merkel who expressed concern about the future of Europe because of the discussion on how to help members overcome the economic consequences of the pandemic (Lindhout, 2020). For example, in the middle of the pandemic, the Dutch demanded strict conditions to help the countries of South Europe like Italy.

Others have posited that this will be the G-Zero world. A world without a leading nation. Or an era of a new Cold War between the United States and China, with Europe in the middle being forced to choose an economical and technology partner (van Noort, 2020; Bloomberg News, 2020).

In June 2020, the G-Seven meeting was canceled, and there were thought to start a D-10 focusing on democracies and that Johnson from the UK was to lead the group. On the $18^{\text {th }}$ of June 2020, President Trump declared the possibility of decoupling from China as a response to the new outbreak of the virus in Beijing because he did not trust the numbers that China was publishing.

Not everybody agrees that we are entering another Cold War era. On the contrary, they expect that the world will collaborate more. "The coronavirus pandemic may mark the endpoint of the post-Cold War era. The enchantment with ever-greater international integration is gone. But it would be folly to replace globalization with the same kind of isolationism and protectionism that has impoverished nations before. The nature of globalization's next phase - and the precise contours of a more selective pattern of crossborder engagement and interdependence after the pandemic - will be the larger question against which many of the most important political debates of the coming years will play out." (Fontaine, 2020)

Walt thinks that if a Cold War emerges, it will not escalate into a war, at least in the short term, or it will not be a war as we know it. He believes the pandemic will promote collaboration and peace (Walt, 2020). In this context, it is mentioned that China did not step up to the plate of world leaders during the pandemic but had chosen to fight with other countries.

As China's weight in global affairs grows, it will have to take on greater responsibilities. America has progressively walked away from the family of United Nations institutions. China has not, and may use its new confidence to take on a larger role. For example, before the pandemic the World Health Organization (WHO) had been weakened by an effort led by the West, starting in the 1970s, to reduce the share of funding that member states are obliged to pay and make the majority of its budget come from voluntary contributions. Today, some $80 \%$ of WHO's budget is voluntary. China could demonstrate global leadership by calling for a charge to restore the mandatory funding to its earlier level of 
around $60 \%$, since WHO can only develop long-term capabilities on the basis of predictable, compulsory contributions.

But that may just be a start. The world after the crisis may see a hobbled West and a bolder China. We can expect that China will use its power. Paradoxically, a China-led order could turn out to be a more "democratic" order. China doesn't want to export its model. It can live with a diverse multi-polar world. The coming Asian century need not be uncomfortable for the West or the rest of the world. (Mahbubani, 2020)

The conflict between the US and China regarding the World Health Organization illustrates the new geopolitical dynamic. The USA accused the WHO of protecting China in the matter of the outbreak and stopped its contribution to the WHO. China responded a few weeks later by pledging US $\$ 2$ billion in funds to the WHO to handle the pandemic (China's Xi says supports WHO probe, pledges US\$2 billion to deal with COVID-19, 2020). President Trump responded that the cut-off by the United States would be permanent. On the $29^{\text {th }}$ of May 2020, Trump announced that the US was abandoning the WHO (Relman \& Haltiwanger, 2020). Trump stopped the U.S. funding of the WHO, accusing the organization of not having acted swiftly when it all started in China.

Bloomberg published an article on this. "The Health of 7.8 Billion People Is Stuck in a Dangerous Place Between China and Trump. The World Health Organization is fighting the worst pandemic in a century and facing an unprecedented political challenge."

Soon after this fight about the funding of the WHO, China went after the United States for the US\$1 billion the United States still owed the United Nations (China Goes After U.S. Over More Than \$1 Billion Owed to UN, 2020).

When President Joe Biden took office in January 2021, one of the first things he did was rejoin the WHO and Paris's climate treaty.

On the $26^{\text {th }}$ of May 2020, Australia also angered China when it asked for an investigation of the virus's breakout. China responded by threatening export measures (Westcott, 2020). At the same time, China started to talk about increasing its readiness for armed combat (Tian, 2020). On the $19^{\text {th }}$ of June 2020, all sectors in Australia reported that they were under cyber-attack. China stated that it has nothing to do with it.

The geopolitical shift is not only about the US and China. As Venezuela could not produce oil because the industry had imploded, it started to import fuel from Iran. In April and May 2020, there were many movements in the Caribbean basin (Sutton, 2020).

If we look at the role of global institutions besides WHO, the following insights have emerged. The IMF announced some debt relief for developing countries to give some room to deal with the pandemic. (OK, we did it, 2020). It is unclear if this IMF announcement is real. In any case, debt will be an issue for many countries. The debt will increase, and they will have great difficulty paying back.

The United Nations warned that the Great Lockdown would become the Great Meltdown (Ghosh, 2020). In May 2020, The World Bank and the IMF announced a debt suspension program for developing countries as part of their strategy to help these countries cope with the pandemic (Malpass, 2020). On the $17^{\text {th }}$ of June 2020, the President of China announced that China would pardon the debts of African countries (China to Waive Some African Loan Payments Due This Year, Xi Says, 2020).

The point is that the conflict between the North and the South is a reality that has not been adequately addressed, just like the issue of racism (Fukuyama, 2020). In May 2020, Banerjee and Duflo coined the idea of having a sort of Marshall Plan for the South by comparing the pandemic to war (Banerjee \& Duflo, 2020).

\section{Globalization}

COVID-19 will create a world that is less open, less prosperous, and less free. It did not have to be this way, but the combination of a deadly virus, inadequate planning, and incompetent leadership has placed humanity on a new and worrisome path. It might be the tipping point for globalization. Leaders who 
performed well will improve their status, and those who did not play will blame others. The American citizens will have lost belief in globalization and global trade. If the United States prevails as a great power, it cannot protect its security by acting alone. The United States would be wise to cooperate but probably will not do so. The response of the world might be more nationalist at first, but over the longer term, the democracies will come out of their shells to find a type of pragmatic internationalism. It might be a few years after the pandemic that governments turn outside again (John, Burn, Garrett, \& Haass, 2020).

Many of the key drivers of globalization-shipping, data, and capital flows, our understanding of comparative advantage, and economies of scale-will not go away. But driven by a combination of changes in popular sentiment, government policy, and corporate practices, globalization will change. Driven by a combination of changes in popular sentiment, government policy, and corporate practices, globalization will change. The coronavirus pandemic will mark not the end of an era but its transformation.

First, economies may become less dependent on single points of failure - and less dependent on China. Fragile supply chains are not an indictment of globalization per se, but of the way, companies have become dependent on single sources of supply. It is easy to imagine companies, both on their own and at the behest of their governments, diversifying the supply of key inputs and shifting to domestic or regional production. Advances in automation and other labor-saving manufacturing technologies would make this easier; continued trade war with China would force it along.

Second, economic integration will still take place, but it will continue to shift from the global to the regional and bilateral levels. Global multilateral trade talks have gone nowhere since the Uruguay Round in 1993. Instead, the European Union concluded separate trade agreements with South Korea and Japan, African countries are talking about a continent-wide trade zone, and a pact similar to the planned Trans-Pacific Partnership has taken effect after Washington withdrew. Even China's Belt and Road Initiative is creating regional and bilateral connections, not global ones.

Third, political debates in the United States and many other Western countries are likely to remain focused on globalization's losers and the ways to protect workers from economic damage. The problem is that the preferred remedy - protectionism - makes many problems worse, not better. How to protect workers without undermining globalization's economic benefits, including a higher standard of living, remains an unsolved question. (Fontaine, 2020)

Some observers wonder if the pandemic will mean the decline of emerging markets such as Brazil, Indonesia, India, Russia, and Turkey.

Emerging economies make up around three-fifths of global output, up from one-fifth in 1990. They have generally acted as responsible stakeholders within the global system too, given so many have benefited from its operation. That may no longer be the case. Facing slower growth and angry domestic populations, it is entirely plausible that countries such as India and Turkey will show the same sour, nationalistic recalcitrance more common from Russia, as it seeks to undermine existing multilateral institutions and bully smaller neighbors. Even if they don't, the idea that developing nations will lead the global economy out of its current malaise looks increasingly improbable. Most coronavirus patients stage a full recovery. Emerging markets are unlikely to be so lucky." (Crabtree, The End of Emerging Markets?, 2020). 


\section{Capitalism}

COVID-19 exposed capitalism (Niemuth, 2020; Jacobs, 2020). An estimated one hundred million people have been condemned by the crisis to poverty (World Bank, 2020). "Workers must draw the lessons. A system that funnels trillions to a handful of financial parasites while condemning millions to poverty and death must be swept aside." (Niemuth, 2020). The pandemic will send 60 million people into extreme poverty, living on less than two dollars a day, according to the World Bank (Toh, 2020). Covid-19 might now change capitalism. The market economy has become the market society, and the pandemic can correct that (Carney, 2020).

Certainly, the coronavirus is a serious matter and certainly its spread is a consequence of its own danger to the human body; but there are social issues here that bear serious thought. Key to any discussion has to be the sheer collapse of State institutions in most of the capitalist world, where these institutions have been privatized, and where private institutions have operated to minimize costs and maximise profit. (Prashad, 2020)

Mazzucato puts it as follows.

Covid-19 is a major event that exposes the lack of preparedness and resilience of the increasingly globalised and interconnected economy, and it certainly won't be the last. But we can use this moment to bring a stakeholder approach to the centre of capitalism. Let's not let this crisis go to waste. (Mazzucato, 2020)

Others commented that the coronavirus killed neoliberalism and state capitalism showed its superiority.

If neoliberalism was already on life support, then the coronavirus has administered the lethal blow. The pandemic has laid bare the disastrous consequences of decades of privatisation, deregulation and outsourcing in countries like the US and UK, and highlighted the critical importance of strong public services and a well-resourced state bureaucracy. In order to contain the economic fallout from the pandemic, Western countries have ripped up the neoliberal playbook. Market forces have been shunned in favour of economic planning, industrial policy and regulatory controls. Even the IMF, for decades the standard bearer of neoliberal orthodoxy, has floated policy responses that have more in common with the Chinese model of capitalism. In a recent blog, four senior researchers wrote that: "If the crisis worsens, one could imagine the establishment or expansion of large state holding companies to take over distressed private firms. (Macfarlane, 2020)

In the UK, privatization of the past has weakened the response to the crisis.

The pandemic has also exposed the privatised care system as catastrophically unfit and illprepared. In 1993, 95\% of care at home was provided publicly by local authorities. Now, almost all of it - and almost all residential care - is provided by private companies. Even before the pandemic, the system was falling apart, as many care companies, unable to balance the needs of their patients with the demands of their shareholders, collapsed, often with disastrous consequences. (Monbiot, 2020)

During the crisis appeared that the market is not superior to government and civil society. When the markets came to a halt, the government and civil society continued and stepped in. To illustrated this, in the United States, the government had to step in and pay for corona tests of patients because many patients could not pay, and the hospitals refused to test (Abrams, 2020). The treatment that people receive in intensive care in New York depends on whether they can pay. Those who cannot pay had a severe problem. 
There are also cases where treatment was continued against all the odds because the family wanted it and was willing to pay the bill (Houwelingen, 2020). There was a case reported that a patient received a hospital bill of US\$1.1 million.

The public health care system in Europe proved to be much better at dealing with the crisis (Rabaey, 2020). The testing was essential to identify people who would continue to spread the virus. Even in the Netherlands, on the matter of testing for the presence of the virus, the market failed. At a particular stage, there were not enough tests available. These were produced for $80 \%$ by Roche corporation. The demand was higher than the supply. Others could create the tests except for one fluid that was a secret of Roche ('Bijna-monopolie van farmaceut Roche leidt tot tekort aan coronatests', 2020). After much pressure from the government, Roche released the formula.

To further illustrate the point of the market and its dysfunction, Big Pharma was called upon to develop the corona vaccine, but within the business model of shareholder maximization, this is a huge challenge (Rengers, 2020). Corporations have a psychopathic pursuit of profit above serving humanity (Bakan, 2005).

The coronavirus has laid bare the failures of our costly, inefficient, market-based system for developing, researching and manufacturing medicines and vaccines. COVID-19 is one of several coronavirus outbreaks we have seen over the past 20 years, yet the logic of our current system - a range of costly government incentives intended to stimulate privatesector development-has resulted in the 18-month window we now anticipate before widespread vaccine availability. Private pharmaceutical firms simply will not prioritize a vaccine or other countermeasure for a future public health emergency until its profitability is assured, and that is far too late to prevent mass disruption. The reality of fragile supply chains for active pharmaceutical ingredients coupled with public outrage over patent abuses that limit the availability of new treatments has led to an emerging, bipartisan consensus that the public sector must take far more active and direct responsibility for the development and manufacture of medicines. That more efficient, far more resilient government approach will replace our failed, 40-year experiment with market-based incentives to meet essential health needs. (Coronavirus Will Change the World Permanently. Here's How, 2020)

The market failed in another way. It excludes the poor. In Curaçao, as in many parts of the world, many poor were disconnected from water, power distribution, and internet access because they failed to pay their bills. At the start of the corona crisis, they had to be reconnected because handwashing is the primary method of preventing the spreading of the virus.

The COVID-19 pandemic is a chance to do capitalism differently. What was unthinkable could suddenly become inevitable after COVID-19 (Mazzucato, 2020; Bregman, The neoliberal era is ending. What comes next?, 2020).

But we now have an opportunity to use this crisis to understand how to do capitalism differently. This requires a rethink of what governments are for: rather than simply fixing market failures when they arise. They should move towards actively shaping and creating markets that deliver sustainable and inclusive growth. They should also ensure that partnerships with businesses involving government funds are driven by public interest, not profit. (Mazzucato, 2020)

In the first stages of the pandemic, governments supported companies to save jobs. Soon a debate regarding the imposition of additional conditions began. Certain politicians in Netherland wanted only socially responsible companies to receive support from the government (Kieskamp, 2020).

In Sweden, the government did not support companies that use tax havens. Countries like Denmark and Poland also refused to aid companies that evaded taxes. The argument was that these companies dodge their responsibility to society (Bostock, 2020). A few political parties in the Netherlands hold that position too. 
Already in the middle of the pandemic, the city of Amsterdam announced that it would rebuild its economy based on the principles of the doughnut economy or circular economy (Boffey, 2020). And New Zealand published a billion dollars investment in the creation of 7,000 green jobs to substitute employment in tourism. Specific projects mentioned included natural parks and electric cars (Cotroneo, 2020).

The Dutch television association, VPRO, formulated the reform of capitalism in six points.

- Minimalize tax evasion by corporations

- The rich should pay more taxes than the poor, as is currently the case

- Become a circular economy

- Combine the solution of inequality and climate change crisis by creating green jobs

- Implement (Univresal Basic Income) UBI

- Eliminate bullshit jobs (Kuys, 2020)

Basically, this is a synopsis of the Green New Deal. Rutger Bregman (1988), a Dutch historian and author, mentions the following points when he addresses the question, now that the neoliberal era is ending, what is next? Higher taxation of the wealthy and more robust government must be part of the solution. He reminds us that in 1952 the highest tax bracket in the United States was 92\%, and the economy was growing faster than before the pandemic. Senseless jobs should disappear, and universal basic income should be introduced. Bregman believes, based on the work of Mariana Mazzucato, that it is not the entrepreneurs that create but the entrepreneurial state. The state should invest in the form of the Green New Deal (Bregman, The neoliberal era is ending. What comes next?, 2020).

As the pandemic continued its course, pressure started to emerge on the rich, asking why they do not use their fortune to stop the crisis either by philanthropy or paying higher taxes (Giesen, 2020). During the first two months of the pandemic, the rich got significantly richer. "In total, the roughly 600 US billionaires saw their wealth grow from $\$ 2.948$ trillion to $\$ 3.382$ trillion within the past two months." On the other hand, unemployment rose to new heights (Perper, 2020).

It takes more than markets. We have rediscovered the public sector. It is about the balance between the private sector, public sector, and civil society to serve the people within the planetary boundaries (Meuleman, 2020).

Others warn that there might be a shift from neoliberalism to more power to the state but that neoliberalism will not disappear. This shift might only be temporary (Doherty, 2020).

\section{Governance}

What are the changes in the area of governance? Due to the corona crisis, there is a revived trust in institutions. We understood that government is a matter of serious and capable people and not an arena for emotional satisfaction. We have learned that the free market and its individualism are not absolute. We could turn towards more authoritarianism. The domestic supply chains will be strengthened. We will invest in public goods for health and public services (Coronavirus Will Change the World Permanently. Here's How, 2020; Fukuyama, 2020)

We were taught to dislike the government and institutions.

A key achievement of austerity capitalism has been to delegitimise the idea of State institutions (notably those that improve the well-being of the population). In the West, the typical attitude has been to attack the government as an enemy of progress; to shrink government institutions-except the military - has been the goal. Any country with a robust government and State structure has been characterised as 'authoritarian'. (Prashad, 2020)

Due to corona, we have seen that we need the government and institutions to survive and come back.

In the absence of a widely available vaccine, and knowing this will likely take more than a year, and possibly multiple years, not a couple of months, we must make fundamental changes to our economic system. To prevent an economic collapse, governments will need 
to take on large and unprecedented roles in securing business continuity and jobs. The public debt that will go hand in hand with, will need to be carried by the strongest shoulders - the companies and individuals most able to take it on. The crucial principle, that everyone will need to subscribe to, is that we're all in this together, for the long haul, and we must all come out of it together. (Schwab \& Vanham, 2020)

The expectation that tasks would move from the market domain to the public domain is not met everywhere and right away. In the UK, for example, we saw the opposite. "The government is using the coronavirus pandemic to transfer key public health duties from the NHS and other state bodies to the private sector without proper scrutiny, critics have warned." (Garside \& Neate, 20202).

In an article in Foreign Policy Magazine, the authors state that the pandemic will permanently expand government powers. This has a dark side, a surveillance state where big brother will be watching us. This will happen in democratic and non-democratic countries. Part of this move towards the surveillance state occurred during the implementation of the restrictive measures to flatten the curve.

The state has and will also continue to intervene more as it did with stimulus programs and allocating funds in the medical sector. This has led to cases of fraud and corruption (Winterman, 2020).

Governments have become more data-driven.

By comparison, governments that are responsive, data-driven, energetic, collaborative, and innovative will have proved superior to autocracies in delivering their societies from the coronavirus and its economic costs - leaving these governments strengthened and enjoying greater public trust in the future. (Crabtree, et al., 2020)

There is the dark side of the surveillance state.

As we move toward greater surveillance, we need to figure out how to get the best of both: how to design systems that make use of our data collectively to benefit society as a whole while at the same time protecting people individually. (Crabtree, et al., 2020).

The shape of the future government will be forged in Asia.

In short, the era of big government is returning, but it will manifest itself in ways that are quite different from the previous era of large states during the 1960s and 1970s - and much of its new shape will be forged not in the West but the East. (Crabtree, et al., 2020)

It looks like it has now become more government, less market.

After decades of free-market momentum, governments in developed countries and emerging markets alike are embracing influential and long-lasting roles for themselves in the basic workings of their economies. (Crabtree, et al., 2020)

It is about wealth redistribution.

After three decades of wealth creation on a historically unprecedented scale, we may now be on the cusp of an unprecedented period of wealth redistribution in the form of higher taxes to fund an expansion of health care and other services. We may be on the cusp of an unprecedented period of wealth redistribution. (Crabtree, et al., 2020)

The COVID-19 pandemic has shown us that we need a radical rethink of the production and distribution of food and other essential goods for all of us in society to live in good 
health, peace, and prosperity. We should now be pushing for local, decentralized ownership and co-creation of social goods and services. (Crabtree, et al., 2020)

Some governments are using this crisis to silence critics.

In short, the pandemic makes it clear that human rights should be upheld not only out of principle but for powerful, pragmatic reasons as well. If the public appreciates these reasons, sufficient pressure can be put on governments to prevent them from profiting from tragedy. If not, we may find ourselves in a world with both a greater risk of disease and less regard for human rights. (Crabtree, et al., 2020)

We must make sure this rollback of civil rights does not become a permanent fixture of life in the post-coronavirus era. Shaping the post-pandemic world starts with the acknowledgment that we are all infected by affluenza: We consume too much and equate conspicuous consumption with success and happiness in life. Valuing economies purely on the basis of GDP has been recognized as a failure that must be addressed if we are to have a chance at creating a more equitable world. (Crabtree, The End of Emerging Markets?, 2020)

The conclusion is politics and political institutions will be more virtual, and big government makes a comeback. Government services will regain prestige.

We found that Political institutions started to become more virtual and even meetings and decisionmaking became virtual (COVID-19: Parliament could meet from multiple locations under proposed law, 2020).

We also see the importance of global governance. Institutions like the United Nations, the World Health Organization, and the World Bank will restructure their policies, as mentioned previously.

\section{Civil and Human Rights}

Civil and human rights are also likely to undergo a tectonic shift.

The rules we've lived by won't all apply. Why cut off people from water and electricity? We must change the practices so that untold millions of people are not so vulnerable to begin with. We can expect a political uprising and Occupy Wall Street 2.0. The inequality gap will widen. There will be limits on mass consumption. The end of mass quarantine will unleash pent-up demand for intimacy and a mini baby-boom. The culture will be reshaped around an appreciation for communal life. There will be a revival of parks. There will be a hunger for diversification. There will be less communal dining but more cooking. There will be a change in our understanding of change. There will be no tyranny of habit no more. (Coronavirus Will Change the World Permanently. Here's How, 2020).

Besides human rights, such as access to water and electricity, the crisis reopened a discussion on universal access to the internet. The lockdown during the crisis proved that the internet was essential. One crucial field was education. In education, lack of optimal access to the internet increased the disadvantage and hence the inequality of the weaker individuals and groups in society.

During the pandemic, civil rights were put on hold. This is an essential element of lockdowns. Among others, these rights include the right to move freely, privacy, and the right to assembly. The state power was centralized, and the democratic rule of law was put aside. The issue is whether these rights will be restored after the crisis (Staat perkt burgerlijke vrijheden radicaal in, 2020; Icke, 2020).

One example, several countries, including Singapore and The Netherlands, developed apps to track citizens. The idea was to warn citizens if they have been in contact with people diagnosed as carrying the coronavirus and must isolate themselves. In Hong Kong, arriving passengers were put on a wristband to 
track them during quarantine (Saiidi, 2020). This is considered a severe intervention in privacy and the right of free assembly, the right to safety, the right of health, and the right of non-discrimination (Kerstens, 2020). Apple and Google also started a collaboration to develop tracking technology to fight against the coronavirus.

In several countries, part of the strategy was to protect the vulnerable groups, including the elderly. Some say that in practice, this was not the protection of the elderly but isolation and exclusion (Doorduin, 2020).

After a few weeks in intelligent lockdown in the Netherlands, people and columnists began to protest. They stated that in the beginning, the lockdown might have been justified. Still, after a few weeks, enough was known about the virus, and the citizens had enough information to protect themselves and others. They stated that society was drifting towards totalitarianism (Beckman, 2020; Hoogleraar staatsrecht: noodverordening gaat nu veel te ver, 2020). At the end of June 2020, the Netherland government started the process of making social distancing required by law and forbade protests against such a law. On the $20^{\text {th }}$ of January, 2021, the Dutch government introduced a curfew. On the $16^{\text {th }}$ of February, 2021, a group called Viruswaarheid (Virus truth) won a court case against the government. The curfew was called unlawful. The government had to rush a law through parliament to enforce the curfew still.

This phenomenon is not typically Dutch, but it is almost universal, as exemplified in the United States and even in New Zealand, where the prime minister is considered one of the best leaders by the world (Friedman, 2020). In India, mass protests broke out (The Hope Man, 2020). The point is that to be human is to be free, and the poor, especially in developing countries, are dependent upon a weak social security system. The poor must work to survive. This is a severe problematic issue because there was a real threat of a second wave of contamination by the virus.

The above reminds us of Klein's idea that the capitalist system never wastes an excellent crisis to advance its agenda. There are opportunities to roll back democratic rights and personal liberties and promote global governance (Klein, The Shock Doctrine: The Rise of Disaster Capitalism, 2007). The tech companies will benefit the most from this crisis. The circumstances are ideal for them to forward their technologies and agenda (Klein, How big tech plans to profit from the pandemic, 2020).

An illustration of Klein's point is the abolishment of civil rights during the crisis in Hong Kong by China, which received much attention. In May 2020, China, by law, abolished the two systems model, replacing it with one model. Hong Kong no longer had a different system from the mainland. Hong Kong was no longer autonomous (McLaughlin, 2020). The Hong Kong police banned the Tiananmen vigil for the first time in 30 years on the $4^{\text {th }}$ of June 2020. Still, it was held, but people are concerned that it will be the last time. The truth is that in almost every country, civil rights were under pressure from the government.

Another human rights drama is the potential genocide of indigenous people like the people in the Amazon by the COVID-19 virus (Phillips, 'We are on the eve of a genocide': Brazil urged to save Amazon tribes from Covid-19, 2020). The American Indians were also severely hit. There are no words to describe this tragedy.

The largest protest crisis occurred when a nationwide protest broke out in the United States after George Floyd was brutally killed by police, and the video of the incident went viral. George Floyd's death appeared to have triggered a different issue, an underlying problem that COVID-19 exposed, which was the prevalence of racism.

Besides that, the Black Lives Matter movement has been raising its voice for years in protest to this injustice, and the fact that people just came out of the lockdown changed the dynamic and the perception of a much broader group. Everybody had only experienced the limitation of their rights, and this might have influenced how people experienced and hence reacted to the murder of this Black man (Miller, Lemire, \& Zeke, 2020). Other factors that influenced the situation are the fact that Blacks and other minorities were disproportionally hit by the pandemic, with the highest contaminations and deaths per capita and, for decades, lived marginalized. Studies indicate that Blacks in the United States have been structurally and institutionally marginalized for decades (Bewijs dat zwarte Amerikanen ongelijk behandeld worden is overweldigend, 2020). 
In Germany, a debate began over the idea of removing the term 'race' from the constitution. Prime Minister Johnson admitted that the UK has a dark history that should be discussed. This was also the reaction in France and the Netherlands.

\section{Climate and Nature}

The impact of human activity on climate and nature was one of the factors that caused the pandemic, as already mentioned. The pandemic made the human impact on nature and the environment obvious as the lockdown gave the planet a chance to breathe again. With many factories and businesses closed, fewer cars on the road, and fewer planes in the sky, our natural environment showed signs of recovery, albeit slow (Monks, 2020). Cleaner air and water were observed in cities. Landmarks like Mount Everest were visible after a very long time due to the reduction of air pollution during the lockdown. Polluted rivers in India became cleaner. The channels in Venice were cleaner, and tourists were fined for swimming in them.

However, structural changes are necessary. If nothing changes in the future, one billion people will suffer from the heat in the coming fifty years (Watts, 2020). In May 2020, during the pandemic, a study was published that in tropical countries, more people will die from heat due to the combination of high temperature and high humidity, which will make it difficult and even impossible for people to cool themselves (Amerikaanse klimaatonderzoekers waarschuwen dat klimaatverandering wereldwijd tot een veel snellere toename van hittedoden leidt dan verwacht. Eerdere studies verwachtten dat in tropische landen tegen het einde van de eeuw een dodelijke combinatie van hit, 2020).

The United Nations, on the occasion of the 50th celebration of Earth Day, wondered why we could not fight climate change the same way we challenge the coronavirus (Fight climate change like COVID-19: UN, 2020; United Nations, 2020). The pandemic may accelerate efforts to protect and restore the planet.

Some experts are concerned that we might be too late to save the conditions for human beings on the planet (Raaij, 2020), and they might be right, as personal protective equipment has become a new source of contamination, which suggests that the human race is not learning fast enough. A director. The president of the Dutch Central Bank in the Netherlands stated that if COVID-19 is a meteorite, climate change is the crash between planets (figure 3).

\section{COVID-19, RECESSION AND CLIMATE CHANGE}

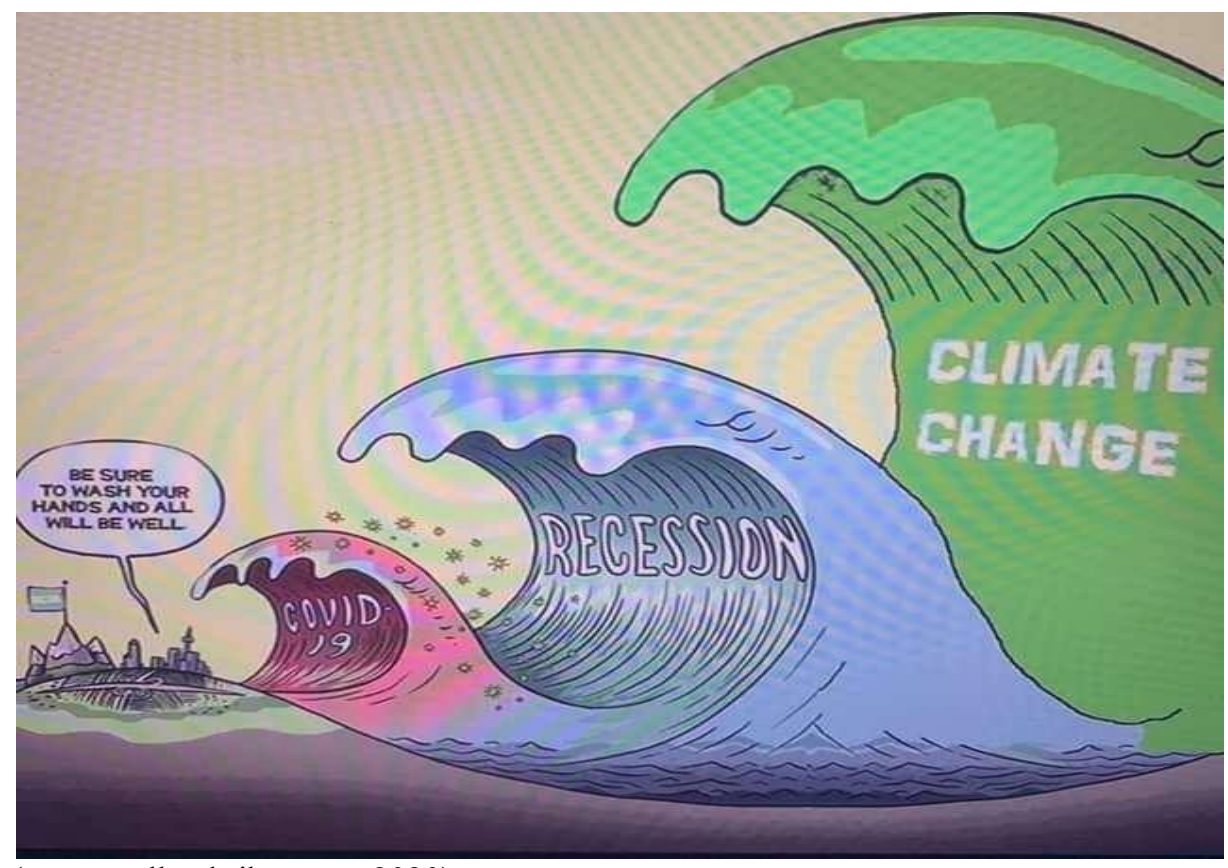

(www.wellandtribune.ca, 2020) 


\section{Economy}

In general, people assume that the economy will enter a recession as a consequence of the pandemic. Goldman estimates a decline in the economy of 35\% in the second quarter of 2020 in rich countries. This is four times the decline of the financial crisis of 2008. It is not clear how the economy will recover (Clenfield, 2020).

The International Monetary Fund (IMF) announced that this depression would be similar to The Great Depression in the 1930s.

The IMF said Tuesday that it expects the global economy to shrink 3\% this year - far worse than its $0.1 \%$ dip in the Great Recession year of 2009 - before rebounding in 2021 with $5.8 \%$ growth. It acknowledges, though, that prospects for a rebound next year are clouded by uncertainty (Wiseman \& Crutsinger, 2020).

This new recession is called The Great Lockdown (Greiff, 2020), and The Times wrote: "Welcome to the First Global Economic Depression of Our Lifetimes."

Unemployment rates exploded as a consequence of the pandemic. "Under the most serious scenario of a $20 \%$ contraction in income, the number of people living in poverty could increase by between 434 million and 611 million," said the report, which is based on an analysis by researchers at King's College London and the Australian National University. (Martin, Half a Billion People at Risk of Poverty From Virus Fallout, 2020). Even in rich countries with a great social safety net, the government plan bureaus expected the explosive growth of poverty.

Early on during the pandemic, companies were declared bankrupt, and small businesses in hospitality and tourism were hit especially hard.

In May 2020, experts announced that the economy had hit rock-bottom, and recovery had started (Bogosavac, 2020). In June 2020, over 2.5 million people in the United States had gone back to work. "A record 2.5 million workers were added by employers during the month, compared with a median projection for a loss of 7.5 million jobs."

The truth is that an economic crisis was expected in 2020, the year of the United States' presidential election (Goede, 2020). The pandemic only accelerated the economic crisis.

We must come out of this recession, and this may not be a V or U recession; it is possible that we are in an L shape recession, meaning a very prorogued recession (Hens, 2020). In other articles, the authors add the W-curve and the Nike Swoosh, also known as the tick-shape. The W-shape will manifest a second lockdown that shuts down the economy again. The tick-shape manifests when businesses and spending slowly return, though slower than before the lockdown (Kennedy \& Jamrisko, 2020). Many expect a long $\mathrm{L}$ with a tail curving upward or a series of Ws (Fukuyama, 2020). (Figure 4.) 


\section{FIGURE 4 \\ THE RECOVERY CURVE}

\section{Jagged Swoosh recovery}

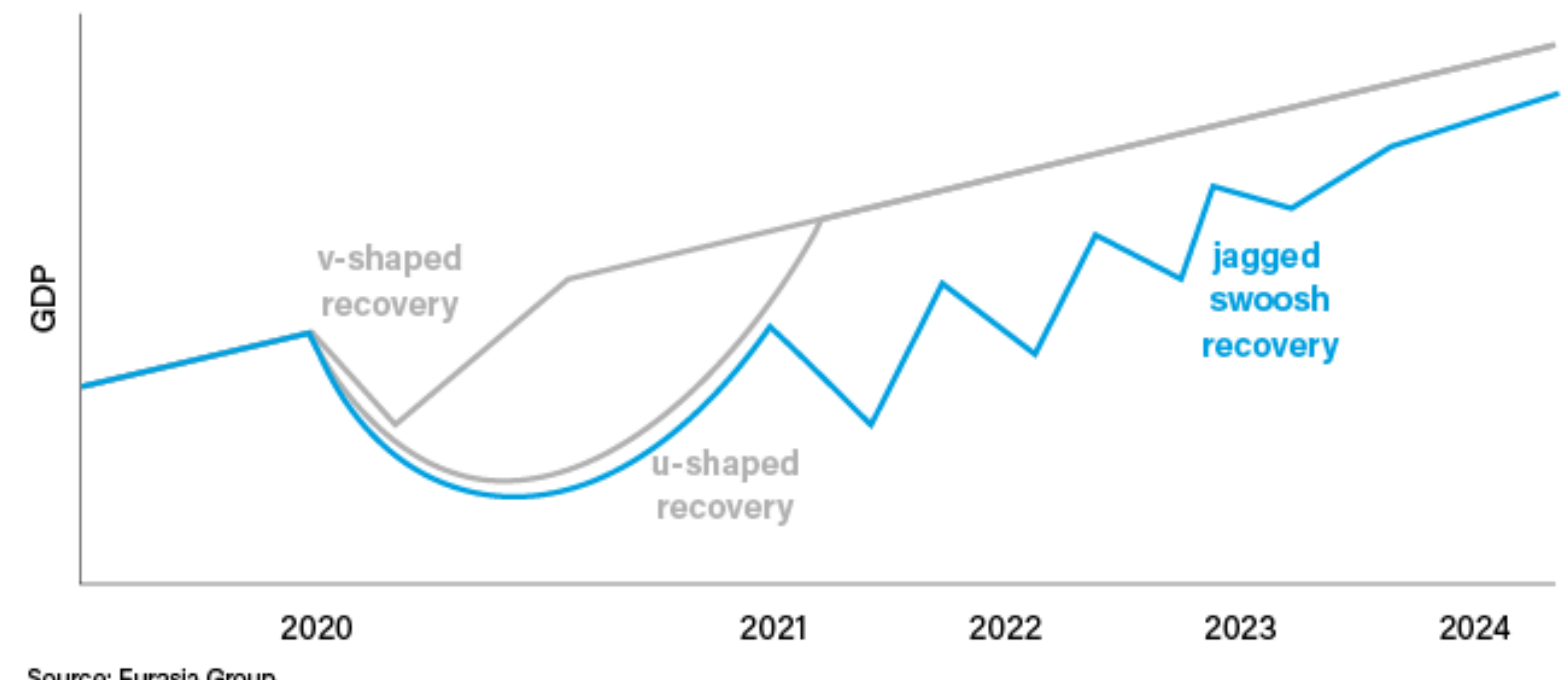

Source: Eurasia Group

One of the pandemic lessons was that we must move away from the immoral economy to a more moral economy (Kadar \& Roth, 2020). In Europe, leaders talk about reopening and resetting with a green economy (van Slooten, 2020). Others prefer the term "circular economy."

However, as studies of the economy after the Spanish Flu have shown, the economy might blossom (Reyes, 2020).

\section{Economic Sectors}

The crisis also showed what economic sectors are vital. It is about communication, transportation, food chain, waste management, and supply chains.

The pandemic forces governments, companies, and societies to increase their capacity to cope with extended periods of isolation (John, Burn, Garrett, \& Haass, 2020).

Global supply chains will change. Supply stability will increase, and profitability will drop. Concepts like just-in-time, globally dispersed production, and warehousing will be evaluated and adjusted. This will not end as an interconnected world. The pandemic is proof of the connected world. It shocks us into realizing the interest in multilateral cooperation on significant global issues (John, Burn, Garrett, \& Haass, 2020; Engelen, 2020).

The commodities, mainly crude oil, decreased rapidly. Oil reached a historic negative value as demand fell because of the lockdown and a fight between oil-producing countries (Winck, 2020).

\section{Science}

The crisis has repositioned science. The ultimate defeat of politics by science occurred when President Trump suggested the ingestion of disinfectant as a remedy against the virus during an official press briefing, which caused an increase in deaths due to poisoning (Aratani, 2020). Later, Trump declared he was using the medicine Chloroquine to protect against being infected with the virus. Science has proven that the medicine had no effect in combating the virus and has serious side-effects.

Science has proven to be essential to the efforts associated with battling the pandemic (Fukuyama, 2020), particularly epidemiology, medical science, and pharmaceutical science. During the pandemic, epidemiologists took center stage, putting even presidents and prime ministers aside unless the prime minister was a scientist herself, as in the case of Angela Merkel of Germany, who performed very well due 
to her background during the first wave (Foster, 2020) (Figure 5). By the $20^{\text {th }}$ of June 2020, the infection rate in Germany was on the rise again.

\section{FIGURE 5 COVID-19 CASES IN GERMANY}

\section{Number of daily recorded coronavirus (COVID-19) cases in Germany since January 2020}

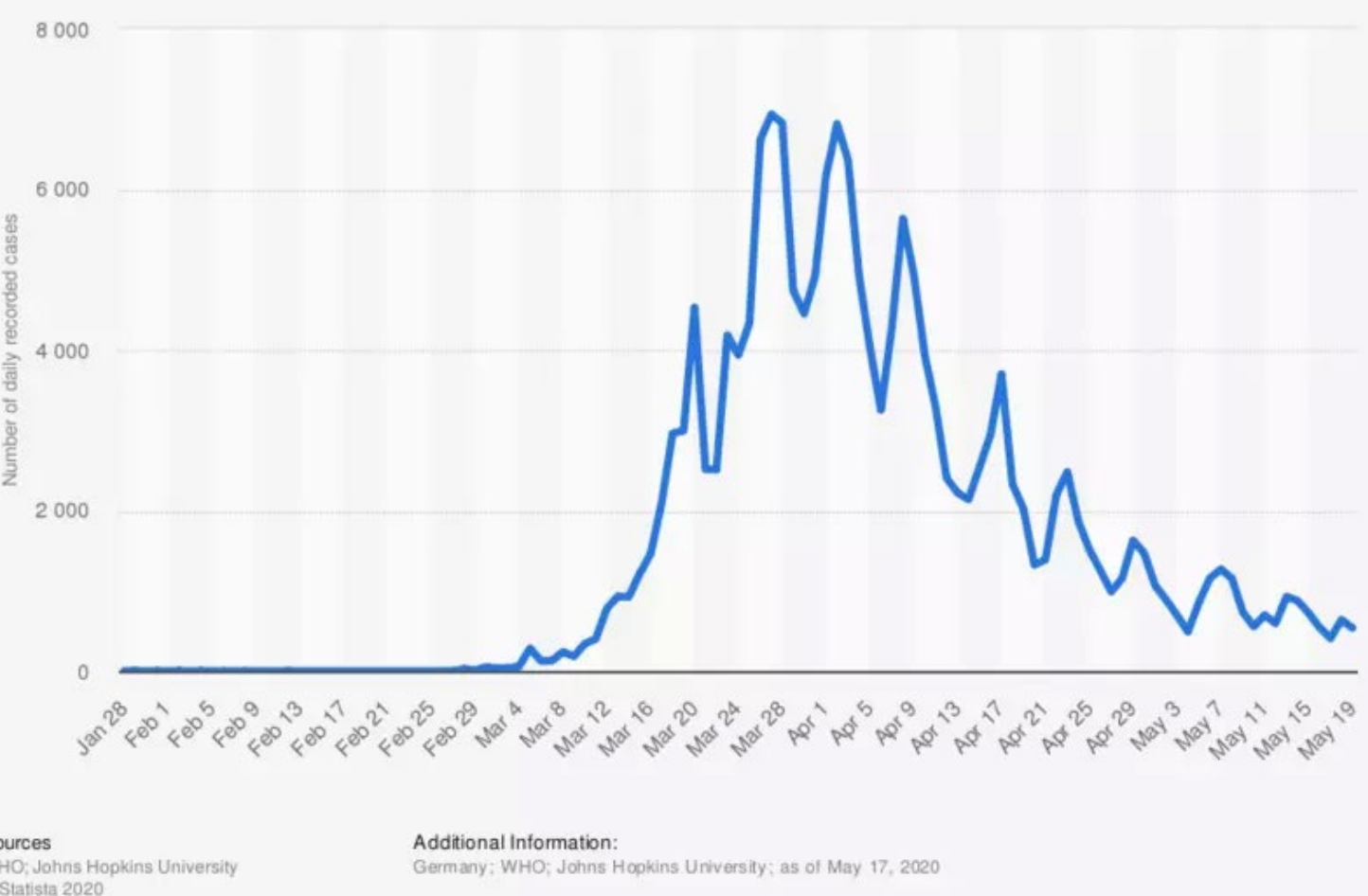

(Spahn, 2020)

The pandemic is a big incentive for science. Many questions must be answered, such as what was the cause, what is the best response, and how to prevent the next pandemic (Doudna, 2020).

Sciences that have to go back to the drawing board include economics as economic systems not only failed but, in a sense, contributed to causing the crisis through the dominant neoliberal school of economics. Computer and data science face ethical dilemmas like tracking citizens to slow the spreading of the virus. In addition, there are psychological questions, such as, how far can psychology go to produce knowledge to manipulate people during a lockdown?

According to van der Tuin, many disciplines have reduced the corona crisis to just two numbers, the number of ICU beds and the number of deaths. This is not good. Although science always reduces reality, this is extreme (van der Tuin, 2020).

Medical science is facing multiple challenges. One of these challenges is the ethical issue of testing vaccines on animals and humans. Even if humans voluntarily collaborate for such studies, it remains a moral dilemma (Kuznia, 2020). The medicine must also reconsider its position to determine if it is to be mainly market-driven or move towards the domain of the state of NGOs.

Pharmaceutical science delivered brilliantly by developing vaccines in a year instead of the projected three years or longer. 
Another issue that science face is related to international students and researchers, who have become restricted due to the lockdown. Many research institutions have become dependent on talent from abroad, for example, China and India. Due to the pandemic, this has become a problem because of travel issues. The question is whether online collaboration is a full alternative for the collaboration of a real physical group (Nelson, 2020).

There are also issues related to online scientific research. The Guardian reported that the productivity of male researchers working from the house increased, and the opposite happened to the productivity of females, which is related to the multiple roles women have at home.

Alondra Nelson, president of the Social Science Research Council, and Harold F. Linder, Professor of Social Science at the Institute for Advanced Study at Princeton University, put forward their thoughts on social science in an article. "For scholars, the question is not only what is society to become after the Covid19 pandemic? But how do the social conditions exposed, exacerbated, and created by the novel coronavirus demand that we substantively rethink our ideas of society and, therefore, some of the prevailing assumptions, methods, and theories of social science?" "In addition to introducing new dynamics, the pandemic has confirmed what scholars have known about social inequality and compounded the intersecting forces of race, class, and gender on disparate life chances. The disproportionate, life-threatening impact of the novel coronavirus on Black communities across the United States, for example, is a symptom of the wider, deeper social pandemic of structural inequality." (Nelson, 2020). How do we reimagine the human sciences with humans flourishing at the center?

Others are concerned with the issue that social science and humanities will suffer budget cuts. This trend existed pre-corona, just when multidisciplinary research is very relevant. One example of the relevance is that multidisciplinary research has shown state intervention might eliminate the small farmer and benefit big corporations. (Czerny, 2020).

\section{Food}

The pandemic precipitated a food pandemic. Experts have pointed out that the lines in front of food banks are historically long, and many people could die from hunger, especially in cities in South Africa and Latin America. The number of people suffering from hunger could double from 135 to 260 million. The causes are loss of income by this part of the population and the disruption of the food supply chain due to the lockdown and the closing of airports and harbors (Zeeuw, 2020).

One example of the disruption was revealed when farmers in England and the Netherland had to destroy potatoes because there was no demand, among others because the restaurants were closed due to the lockdown (Smithers, 2020). The same was the case with the billy goat industry. The demand dropped, and as a consequence, goats were destroyed and processed as dog food.

Because it is probable that the virus started to spread at a wet market, wet markets began operating online, and it is not clear if this will go on (Kit, 2020). The pandemic might also change our diet. We will eat fewer wild animals and less meat because of the danger involved with viruses. It will also impact how we share the planet with other species. We will respect more the territories of these species.

The pandemic will change how we eat and grow our food. Jane Goodall, the lady who in the 1960s changed our understanding of chimpanzees, put it this way, "Now, she says we need to reshape how we think about food - because our disrespect for farmed animals has created this situation where disease can spill over to infect human beings. Goodall advocates a plant-based diet and boycotts of companies that fail to adopt sustainable farming techniques." (We're 'finished' if we don't change after coronavirus, 2020)

More food will be locally grown or even homegrown, which will decrease imports (Campbell, 2020). One of the most critical supply chains that will be restructured is the food supply chain. During the pandemic, the prices of food were driven up. Countries want to be less dependent on food from other counties (Abdullah, 2020). Food security will become a priority (Voegele, 2020). In some places, it sparked a local farm movement (Hiller, 2020). 


\section{Future of Work, Pensions and Universal Basic Income}

As previously stated, remote working has increased dramatically. Research indicated that " $98 \%$ of people surveyed said they would like the option to work remotely for the rest of their careers. But not everything is positive, with workers finding the biggest challenge is 'unplugging' from work." (Routley, 2020). Companies will also become more virtual. The physical presence will decrease if employees work remotely, which will decrease the need for large office buildings.

Corona also revealed which jobs are essential. The essential jobs are not movie actors, sports competitors, or entertainment, and CEOs are not essential either. Vital jobs are jobs in healthcare, cleaning, and communication technology (Stoffelen, 2020). Essential jobs also include market vendors, care workers, medical staff, emergency services, farmers, grocery cashiers and staff, truck drivers/delivery people, cleaners, garbage collectors, security guards. Ironically, we pay astronomical wages for non-essential jobs, especially sports stars, movie stars, music stars, and CEOs (Dunk, 2020).

America has long equated patriotism with the armed forces. But you can't shoot a virus. Those on the frontlines against coronavirus aren't conscripts, mercenaries or enlisted men; they are our doctors, nurses, pharmacists, teachers, caregivers, store clerks, utility workers, small-business owners and employees. (Coronavirus Will Change the World Permanently. Here's How, 2020)

Essential workers in the health care sector were applauded, and they received gifts, but there was little discussion to raise their wages. Other essential workers were treated as modern slaves. They had to continue working on getting an income to live and often did not receive personal protective equipment. Many became sick, and there were deaths on the front line in the war against COVID-19 (Laughland \& Holpuch, 2020). As it was soon formulated, it became clear that we were in a war against the virus.

There is a concern that a significant portion of the jobs lost during the crisis would be permanently lost (Rockeman \& Ward, 2020). Many jobs disappeared, and working from home became the new normal overnight. Home offices and working spots were installed. This was enabled by platforms like Skype, Zoom, and others (Yu, 2020; Mudde, 2020). Google, for example, allowed its employees to work from home until the end of 2022. Twitter announced that some personnel would work from home permanently. This is the trend in all major tech companies (Sandler, 2020). Zuckerberg announced that in 10 years, 50\% of Facebook employees would be working from home.

The crisis also precipitated the discussion and implementation of the four-day workweek on several continents (Berger, 2020; Snouwaert, 2020). Offices changed to meet the standards of the new normal of social distancing and hygiene (Jonk, 2020). This trend affects businesses and jobs around the big offices that cater to the workers in these buildings who are now working from the house. This is the case in Manhattan (Haag, 2020).

The pandemic also sparked a discussion in the Netherlands and the UK regarding sex workers. How could they start to work again and stay safe? Many sex workers took their business online in the Netherlands, Belgium, and other places. Some thought sex workers could use a mask and gloves. For customers, sex dolls became an option. In Curaçao, the biggest organized brothel, was declared bankrupt after 71 years of uninterrupted operation (Drayer, 2020).

During the pandemic, the trend of using robots and artificial intelligence was supported. In Rwanda, robots took the temperature in the city. In Tunisia, robots were used by the police. In the Netherlands, France, and Spain, drones were used to manage crowds.

As unemployment grew to enormous proportions, the income of the unemployment became an issue.

That the share of global wealth and income that workers control is now so low that they have limited reserves when their hard-earned incomes collapse. In the United States, one of the wealthiest countries in the world, a 2018 Federal Reserve study found that $40 \%$ of U.S. households do not have the means to deal with unexpected expenses of around $\$ 400$. The situation is not much better in the European Union, where the Eurostat data shows that 
$32 \%$ of households cannot bear unexpected expenses. That is why in the capitalist States, there is now openly talk of widespread income support-even a Universal Basic Income-to manage the collapse of livelihoods and to stimulate consumer demand. (Prashad, 2020)

"The economy and social order will collapse if the government doesn't guarantee income for people who lost their jobs. People are finding new ways to connect and support each other in adversity." (Coronavirus Will Change the World Permanently. Here's How, 2020) Universal basic income (UBI) was put on the table (Bregman, Is de tijd voor een gegarandeerd basisinkomen nu gekomen? ,2020). Even Pope Francis mentioned it (Panetta, 2020). UBI is not only a way to help people exist, enhance their quality of life, and redistribute income, and it is also a way to increase the purchasing power needed to get the market going (King, 2020). Several studies have proven that UBI works (Henley, 2020).

Spain introduced UBI permanently during the pandemic (Zeballos-Roig, 2020). In the United States, there are propositions to provide citizens with an income of $\$ 2,400$ per month for at least one year after the crisis. "This proposal also outlines the possibility of using the infrastructure behind U.S. Debit Card system to create a "digital public currency wallet system," or a digital currency based on U.S. dollar." (Guina, 2020).

The pandemic appears to have also impacted the pension system and companies, and their investment portfolio decreased by billions as the stock markets came down (Grote pensioenfondsen diep onder water: 77 miljard verdampt, 2020). In the future, pensions may be in a form of UBI.

\section{Cryptocurrency}

Some have argued that the pandemic will speed up the development and use of cryptocurrency. In the United States, the introduction of a "digital public currency wallet system" or a "digital currency based on the U.S. dollar" has been suggested (Guina, 2020). Also, in China, there is a movement towards cryptocurrency. Some remark that cryptocurrency will make the flow of money very transparent and more traceable.

\section{Health Care}

There will be attempts to strengthen global public health governance, but in the setting of weakened globalization, this will not be easy. The pandemic will alter healthcare and public health. Health will no longer be an individual matter (Bachelet, 2020), but everybody and the state will hold you accountable for your health because your health impacts the health and the economy of others. Healthcare will shift from the market domain to the domains of governments and NGOs (Spinney, The World Changed Its Approach to Health After the 1918 Flu. Will It After The COVID-19 Outbreak? 2020; Prashad, 2020).

"A healthier digital lifestyle will be pursued. Telemedicine will grow, and there is an opportunity for more robust family care, and even Universal Family Care (Coronavirus Will Change the World Permanently. Here's How, 2020)."

A mental health crisis has emerged, which the pandemic triggered in the form of the lockdown. With roughly 2.6 billion people around the world in some kind of lockdown, we are arguably conducting the largest psychological experiment in history. This will result in a secondary epidemic of burnout and stressrelated absenteeism in the latter half of 2020 (van Hoof, 2020; Venhuizen, 2020). Anxiety and depression can also be added to the list (de Rooij, 2020). Others claim that the lockdown was positive for mental health. It helped people de-stress, relax and, recover from their stressful existence (Gravemaker, 2020). In any case, in the Netherlands, before the lockdown, people lined up to stock drugs to use during the lockdown. The general public stocked soft drugs, while the elite stocked heroin.

Soon there were also concerns about our immune system. Experts have suggested the immune system may be weakening due to the constant sanitization of hands. Some started to recommend not sanitizing the hands of children all the time. In some cases, it was suggested to experiment with young people by letting them live without keeping social distancing as it is generally assumed that the body of young people could handle the virus.

In short, healthcare will no longer be an individual matter. It will be about lifestyle and telemedicine. 


\section{Family Structures and Living}

During the pandemic, human contact became virtual. Funerals, weddings, dating, and even sex because virtual. Family structures will be evaluated because the singles (Launspach, 2020) and the elderly, especially those living alone, suffered the most during the lockdown from isolation and loneliness. In many European counties, the elderly living in houses for the elderly had a high death rate. Healthcare officials in charge of advising the government how to manage the pandemic in the Netherland advised singles that having one "sex buddy" was safe during the crisis. Other countries began giving the same advice. Other publications indicated that single people started to appreciate companionship more than casual sex.

The divorce rate in Wuhan increased after the lockdown. We do not know the numbers of other countries, but there are indications that there were more stress and even domestic violence, especially during the lockdown. In Singapore, during that period, domestic violence increased by $22 \%(22 \%$ increase in family violence reports since start of circuit breaker period, 2020).

During the lockdown, people rediscovered the neighborhood and their neighbors. Many started to interact and socialize with their neighbors (Weg met de schutting: betere buren door coronacrisis, 2020).

It seems that cities are losing residence who move to the suburbs because the city is expensive, unemployment is high, and bars, restaurants, and entertainment are restricted (again, 2020). Transpiration will change in cities. This is explained in the paragraph on travel.

So what happens in the house will change, including how we visit and receive guests, how we celebrate birthdays and weddings, and how we say goodbye to those who pass away.

The crisis will affect how we dress. We will buy fewer clothes. We will wear clothes longer and not change fashion many times per year. The facemask and other protective gear will be added to the dress code.

\section{Learning}

During the lockdown, distance learning was introduced abruptly on all levels. Universities announced that they are considering canceling all in-person classes by 2021 and that all classes would continue via distance learning online (Ries \& Wagner, 2020). Institutions like Harvard started to offer free online programs (Home-based learning: Harvard University is offering 67 free online courses, 2020). Cambridge announced that all the classes of 2020 - 2021 would continue online (Cambridge University will hold all classes online for the 2020-21 academic year, 2020). This endangered the continuity of some business schools because students wondered why they should keep paying the high tuition fees if there are online options. Online classes could replicate the offline experience. After the lockdown, distance learning might remain in place (Broom, 2020). In the Netherlands, the number of students increased due to the possibilities of distance learning and the fact that the prospect on the labor market for young people was no favorable after high school after the pandemic.

In May 2020, schools started to open, applying the new normal of social standing and learners wearing personal protective gadgets (Lessons from around the world: How schools are opening up after COVID-19 lockdowns, 2020). In June 2020, Korea had shutdown schools again because of a new wave of spreading of the virus. The crisis will have a divesting effect on students' future economic position. \$10 trillion according to the World Bank (Martin, Students Face \$10 Trillion in Lost Earnings Due to Pandemic, 2020).

\section{Travel}

The pandemic could lead to a reset of the travel and tourism industry (Walgien, 2020). Pessimists are even talking about the end of tourism (Perkins, 2020). The airline and cruise line industries will change in the short and long terms. Many people have become scared to travel (Matei, 2020). Some experts expect city trips by airlines to decrease dramatically in the future. Cities like Venice and Amsterdam will take the opportunity to make policies to reduce tourism and thus improve the locals' quality of life. Some experts expect traveling and tourism to boom after the lockdown because people will need a vacation. The observers also predict a rise in domestic travel, the so-called staycation. Traveling has become cumbersome and expensive, and many people have lost their job, income, and money during the crisis. 
Some think that it will be three years or more before air travel reaches the pre-corona level. Travel will be impacted by the social distancing of 1.5-2 meters, thus increasing video conferencing (Mühlberg, 2020). Emirates airlines introduced instant pre-boarding testing of passengers (Cripps, 2020), though it is not clear whether it will become a universal practice. The German airline industry soon reported that they would fly with passengers using protective gear (Vliegverkeer heropstarten met mondkapjes voor alle passagiers, 2020).

Changes have been implemented at airports, airplanes, and destinations (Siret, 2020). Some expected that in the future, it would take four hours before a passenger will board an aircraft. It will have to do with Self Check-In, Disinfection, and Immunity Passes. Besides making sure that there were weapons and explosives on board, the reminders of 9/11 will be about making sure there is no COVID-19 onboard.

Border control and testing passengers became vital. Airports and airlines established protocols (Pre, 2020). Testing is relative because plane passengers tested negative for coronavirus before flying, then positive on landing. A total of 12 out of 91 passengers on a Qatar Airlines flight to Athens, Greece, tested positive when they landed despite being screened before they boarded.

The fact is that there is a growing consensus that traveling by airplane, ship, train, and other means will change (Smith, 2020). The face mask became the new normal on aircraft and trains after this measure was initially discarded in many countries in the West as being inefficient.

Many airlines got into financial trouble as almost all the aircraft were on the ground, and income dropped to the bare minimum (Kotoky, 2020). Some airlines went bankrupt. Others, like KLM, were bailed out by the government using billions from taxpayers. The German government bailed out Lufthansa with 9.8 billion dollars. Germany took a $20 \%$ stake in the company and will sell these shares in 2023 . In the United States, the train company Amtrak also needed a bailout of $\$ 1.5$ billion.

Attractions like Disney announced that their parks would be closed until 2021 (Slagmeulder \& de Slagmeulder, 2020). In the Netherland, attraction parks announced that they would open at the end of May 2020. In May, Disney Shanghai opened after three months again.

The fact is that nobody knows what the consumer will do. Carnival cruises report in May 2020 that their booking for August 2020 has soured with 200\% to August 2019. The costumes are mainly young people not concerned about the virus and tired of the lockdown (Grothaus, 2020). Other experts also consider the scenario that the demand for vacation and travel will explode after the lockdown. Because they expect that people want to go out, people have their interpretation of living with the virus. The whole industry, especially the hotels, are implementing contactless and, in some instances, robotized service (Min, 2020).

In the Netherlands, the railway company proposed that passengers booked their tickets and seats online. This to implement social distancing in trains (Moeten wij binnenkort een treinreis resereveren?, 2020). Soon this was also suggested for other forms of public transportation, such as buses.

There is a shift from public transportation to the car, bike, e-bike, and other small vehicles. This shift is explained because public transit is a place where the virus is quickly spread. In London, restrictions were lifted for bicycles and not for cars. Cars were banned to encourage bikers and pedestrians (London streets to go car-free to encourage walking and cycling amid COVID-19 social distancing restrictions, 2020). In the UK, there was a spike in the sale of bicycles. The pandemic could start a golden age of cycling all around the globe.

\section{Religion and Mass Gatherings}

Religious gatherings played a crucial negative role in spreading the virus. During large religious gatherings, the virus was spread in, for example, Korea (Tens of thousands defy Bangladesh lockdown for imam's funeral, 2020). Sports events had the same impact in, for example, Italy and Spain.

During the lockdown, online concerts by orchestras and musicians were held by making use of conference call platforms and sharing them on social media.

Netflix capitalized on social isolation. The Oscars dedicated more attention to streaming movies. There was talk about drive-in movies and drive-in discos in Germany and other places, such as Aruba (Ook zo'n zin om te feesten? Deze club heeft een Autodisco, 2020). Movie theatres opened again, reducing the number 
of people allowed in the theatre by $75 \%$. Restaurants and café adjusted to takeout and used screens on round tables for sitting customers.

In June 2020, Nijmegen, the Netherlands, started to experiment with social distancing in nightclubs. In New Zealand, it was possible to fill a stadium with 20,000 people because they were virus-free and opted to remain close. A few days later, two new cases were registered, ending a 24-day streak of no cases.

Gaming and e-sports are growing. One example is the success of virtual auto racing. Soccer is trying to come up with a new formula. So far, the public is not allowed during games. The Olympics of 2020 have been postponed until 2021. If by then they cannot go on in 2021, they will be canceled.

In Curaçao, some high schools had used drive-in graduation ceremonies. In Japan, they used robots in these ceremonies.

Swimming, especially on the beach, is a huge challenge when it comes to social distancing. In the Netherlands, there are experiments with drawing circles on the beach.

Last but not least, the mass protest has also changed. After the lockdown, there was a lot of protests all around the globe. There was the concern that these would become super spreading events. There were guidelines for social distancing and facemasks. In general, these events did not become super spreading events. Experts believe that this is because they were held in open-air and that many participants wore facemasks.

\section{CHANGE WILL TAKE PLACE IN STAGES}

First comes the emergence from the lockdown. They call it the new normal. When cases of COVID-19 go down, countries come out of lockdown. The new normal is living with social distancing and washing hands frequently (Lacina, 2020). When cases decrease, citizens are allowed to enter their home country. They will go to quarantine for fourteen days. Local businesses will open. Some sort of health certificate will be put in place for non-residents to visit foreign countries.

The crisis is also an opportunity (Sneader \& Singhal, Beyond coronavirus: The path to the next normal, 2020), but there will be a period of about two years when experts say we must practice social distancing (Rosman, van Assen, \& van Zon, 2020). One of the facts complicating matters is not only that it will take approximately two years to develop a vaccine, but also that experts of the World Health Organization and others are not sure that patients become immune to the virus after recovery (No evidence that people who have survived coronavirus have immunity, says World Health Organisation, 2020). Scientists of the WHO estimates that it could take even up to five years to have the whole situation under control (Meredith, 2020).

\section{Coming Out of the Lockdown}

Coming out of lockdown will be fragile, partial, and slow (Schwartzel, Sider, \& Haddon, 2020). Harvard and others estimate that there will be social distancing until 2022 (Tozzi, 2020). Other sources mention 2023. After the hammer, it will be dancing with waves (Figure 6).

Coming out of the lockdown is a matter of tracing, testing, and isolating people infected by the virus. Many look to Korea because this is considered acceptable in a democracy (Ryan, 2020). Still, after a brief period of success, Korea needed to lockdown for a second time, and even schools had to be closed again. 


\section{FIGURE 6 \\ THE HAMMER AND DANCE}

Chart 13: Suppression vs. Mitigation vs. Do Nothing - early on

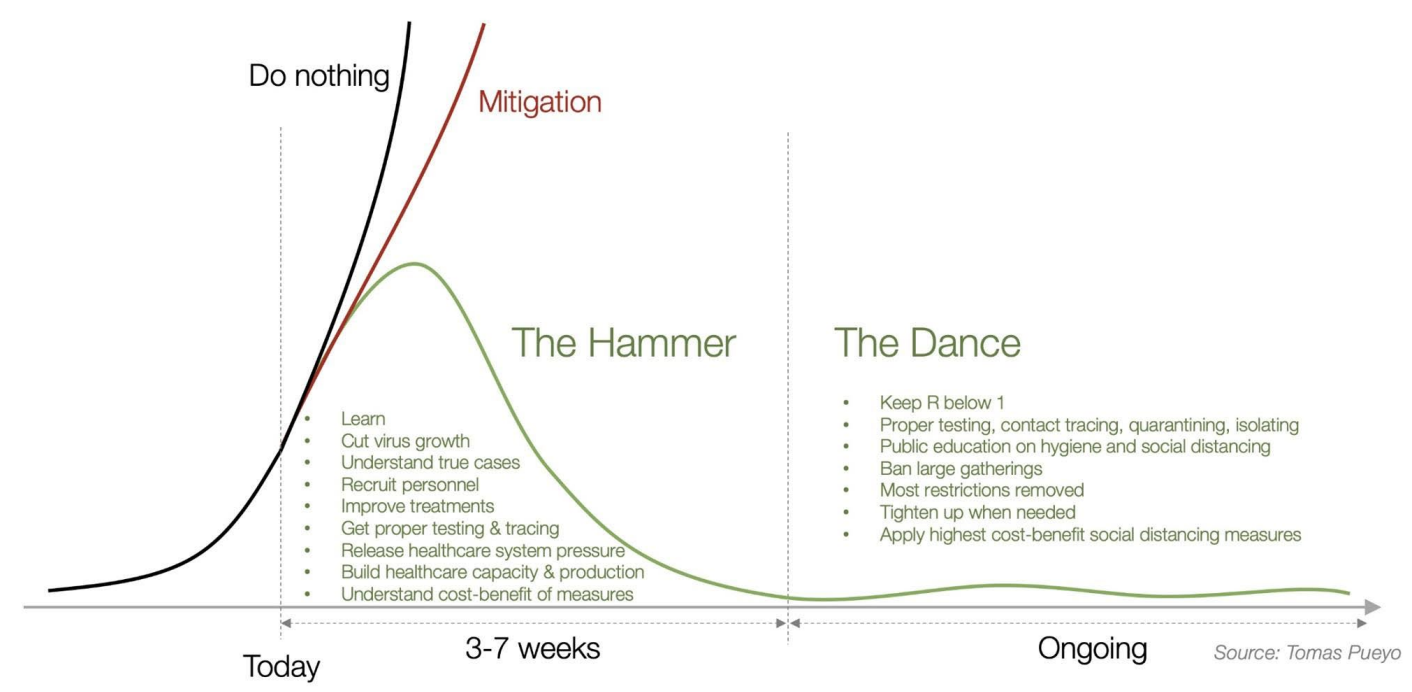

(Pueyo, The hammer and the dance; What the next 18 month could look like, 2020)

In June 2020, the number of people infected was higher globally than ever. Over 250,000 in two days (Nieuwenhuis, 2020).

Brzeski \& Smith foresee four scenarios for the global economy after Covid-19. Scenario. 1: Our base case. It assumes that lockdowns eventually manage to flatten the curve, although not entirely. Given socioeconomic tensions and the significant economic fallout, the first European governments decide to begin relaxing the lockdown measures at the end of April. Others will follow in May. The return to normality is gradual, and social distancing continues for at least the entire summer.

Scenario 2: Winter lockdowns return. It starts in much the same way, with a gradual easing of lockdown measures in May and June. However, in this scenario, the virus returns in the autumn, and despite more widespread testing efforts and contact tracing, the new spread pushes most economies back into lockdown.

Scenario 3: The 'best' case. In the 'best-case scenario, the Western world follows China's footsteps by ending the lockdowns as soon as the curve of new infections has been flattened. A quick return to normality is assumed to materialize towards the end of April. This scenario also believes that the virus does not come back again in the winter, either because a larger than expected proportion of people have already had the virus and built immunity or because control measures become much more effective.

Scenario. 4: The 'worst' case. We assume here that the lockdown measures last until the end of the year. We're assuming that things return to normal from 2Q21, perhaps if a vaccine is developed and able to be deployed over the winter months. The recovery here may be a little faster and more robust than in the other scenarios, as the virus is assumed to be entirely under control. This is an 'L-shaped' recovery. This is an extreme scenario with lots of economic, social, and political turmoil, and one that looks pretty unlikely at this stage. (Brzeski \& Smith, 2020).

Scenario 4 has been eliminated. No country will remain in lockdown until the end of 2020. Others present three scenarios as illustrated in Figure 7 (Woodward \& Su, 2020; The Future with COVID-19: Three Potential Scenarios, 2020). 
FIGURE 7

THREE POSSIBLE WAVE SCENARIOS

\section{Scenario 1: Peaks \& valleys}

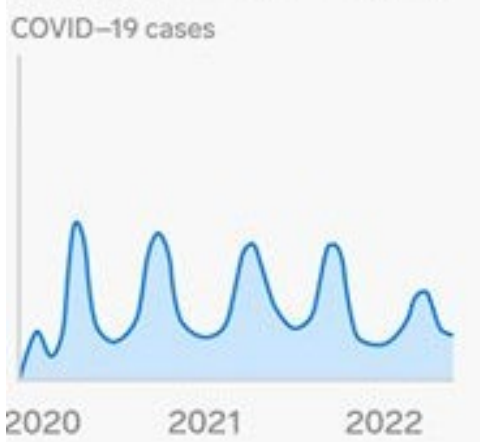

\section{Scenario 2: Fall peak}

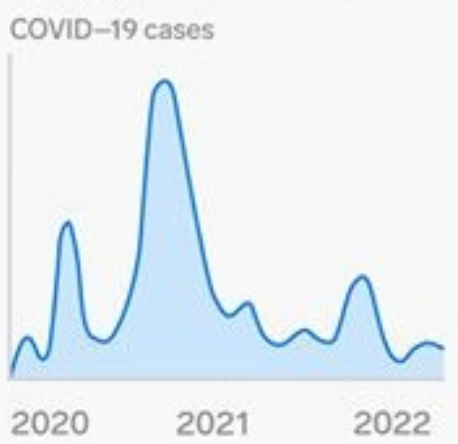

Scenario 3: Slow burn

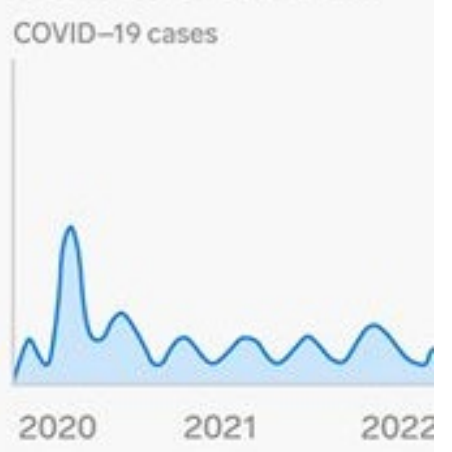

(Woodward \& Su, 2020)

The pandemic, the deaths, and the lockdown have left psychological scars that have to be addressed (Manson, 2020). Coming out of lockdown appeared to be a complicated process due to human behavior. After weeks of staying at home, people cannot control their urge to get together. This behavior is often the start of the next wave. Also, people came out angry and frustrated, which led to significant protests all over the globe. Many were ignited by the death of George Floyd, an Afro-American or black man, in Minneapolis, but it was also fueled by other forms of injustice revealed by COVID-19.

Figure 8 helps to understand these protests against the lockdown and even milder preventive measures. When the curve was flattened due to preventative measures, citizens started to believe that the authorities overreacted. Many people began to behave as if there was no pandemic (Cosslett, 2020). It is unclear how citizens may react to the measures taken when the second wave hits.

\section{FIGURE 8 \\ PROTESTS EXPLAINED}

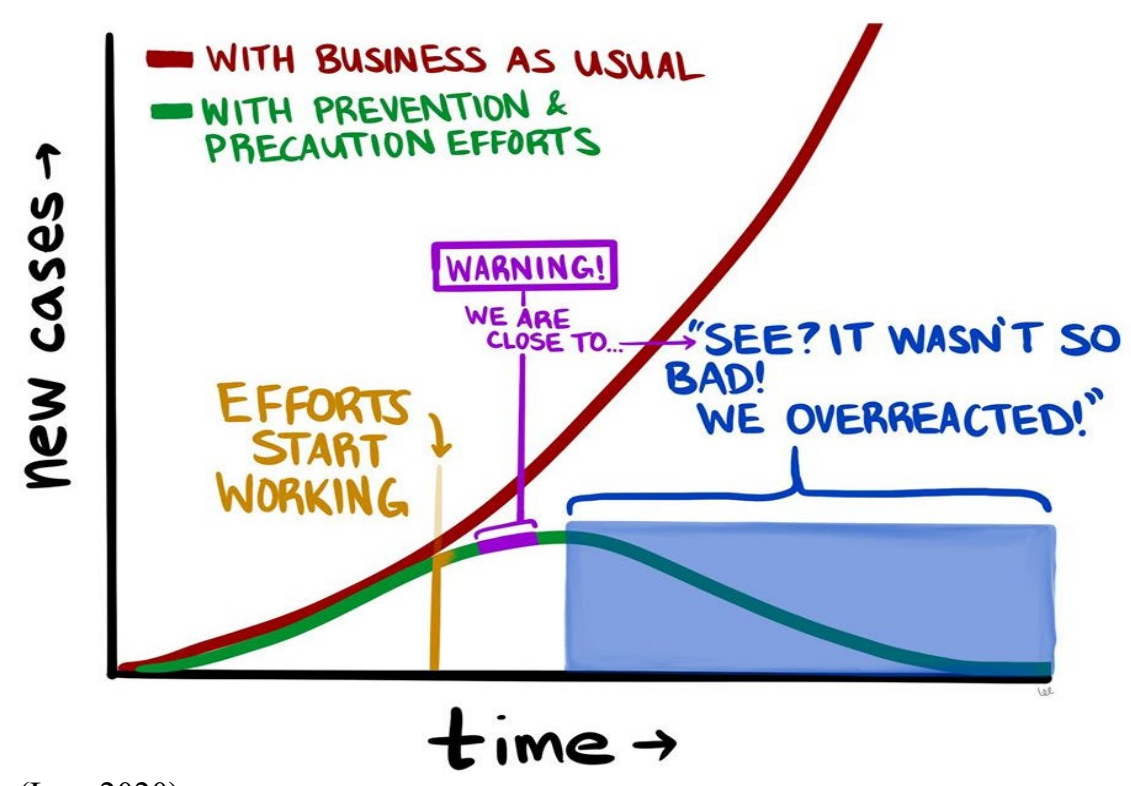

(Lee, 2020) 
These mass protests went global. In countries like the United States, UK, Belgium, and the Netherlands, statues of people associated with the slave trade were taken down. The removing statues of Christopher Columbus, Winston Churchill, and Mahatma Gandhi. King Leopold II was also discussed, touched, or removed. Other symbols associated with racism were also abolished. In France, the president stated that France would not participate in such a movement. In the Netherland, the prime minister, a historian, declared a dark side of history. This should not be removed but made explicit and discussed openly.

In the Netherlands, the controversial Saint Nicolas and his Black Petes, traditionally held in December, seemed to undergo fundamental changes as a consequence of the death of Floyd. Some municipalities announced the abolishment of this century-old tradition after the prime minister expressed that he has a different understanding of this feast now (Utrechtse gemeenteraad: Het is tijd om afscheid te nemen van Zwarte Piet, 2020).

During these protests, the role of social distancing was not taken into account. This led to a new increase in infections. In several countries, this started the second wave. In the Netherlands, this did not seem to be the case.

There was a debate whether the United States was experiencing a resurgence in the first wave of the second wave. In mid-June 2020, there was concern that a second wave had begun in Beijing, China. This was also related to a market where salmon from Europe were sold. China claimed that the virus was imported from Europe and halted the import of salmon from Europe. Cynics say that China is distracting the world because matters regarding the virus are not under control in China.

The WHO declared on the $22^{\text {nd }}$ of June 2020 that the number of cases was still rising, accelerating a pandemic. This was the zenith of the second wave in places that came out and were opening after the lockdown, and the rising numbers of infection cases in areas still coping with the first wave (COVID-19 pandemic still accelerating: WHO chief, 2020). (COVID-19 pandemic still accelerating: WHO chief, 2020).

\section{SCENARIOS AFTER COMING OUT OF THE LOCKDOWN}

Gambuto has speculated that many will want to go back to business as usual, and they foresee a mass marketing campaign to convince consumers that nothing significant has happened. He calls this the ultimate gaslighting (Gambuto, 2020). Sales of luxury brands dropped. The purchasing power of consumers has changed. Brands are selling less, indicating a trend in consumer behavior.

Some authors believe that this change will take place in the following stages: Resolve, Resilience, Return, Reimagination, and Reform. First, we must resolve the problem with the virus. In the face of challenges, resilience is a necessity. We will try to return to what is disagreeable and possible. We will reimagine reality, how we live, how we work, and how we use technology. We will reform the government, private sector, and civil society according to those paradigm shifts, and the government will play a more coordinating role. (Sneader \& Singhal, Beyond coronavirus: The path to the next normal, 2020).

Holthaus (2020) sees three areas when changing the world. The first is to reduce fossil fuel by nationalizing this industry along with the airline industry. This may be possible because of the dropping oil prices. Secondly, the government should start significant public works, taking advantage of the low interest rates. Lastly, the government should strengthen social safety nets, including universal basic income (Holthaus, 2020).

For change to happen, the currents of money must be redirected, according to Ann Pettifor. That is what happened after 1929 when we came out of the Great Depression. This was not the case coming out of the financial crisis of 2008. Banks were bailed out using public money at the expanse of public services like healthcare, culture, education, and public transportation. The next financial crisis was created by the solution. Before the next financial crisis arrived, we were hit by the pandemic. As a consequence, the economy has and will continue to shrink (so far, the United States by $5 \%$, Europe by $8 \%$, and China by $13 \%)$.

The virus exposed the weakness of the current systems. The system was (and still is) driven by shortterm profits. There is a battle between two ideas. On the one hand are those who want to save people and the planet and, and on the other side are those who want to get the global financial system going again. A 
Green New Deal synchronizes the economy with solving social needs by considering the planet's carrying capacity. It is about people and the planet first. It is about self-reliance through care, public transportation, education, and culture. The needs of people are met, and wants are limited. A Green New Deal is only possible if the financial sector is tuned into this via government intervention. Currently, the financial system finances big oil companies. This is bad for the climate. Companies that receive public money must accept conditions that enable the objectives of the Green New Deal (Hens, 2020; VPRO, 2020). To mitigate the economic impact, governments and international organizations intervened by pouring huge amounts of money into the economy. The European Union financed countries to the tune of 750 billion Euros (Wiel, 2020). These investments must be aligned with the Green New Deal agenda. The Pope also asked the faithful not to invest in fossil fuels and the defense industry (Pullella, 2020).

The reset might have possible outcomes that can generally be organized into four categories (Figure 9). The four scenarios are constructed by combining two spectrums. The first is the degree of centralization of power and structure in society, ranging from very centralized to completely decentralized. It somewhat corresponds with the spectrum Centralized Response versus Disruptive Response of Mair (2020) and the spectrum Adaptive Capacity of Rockefeller Foundation (2010). The second spectrum range from a very individualistic society to a collectivistic society (We). Exchange value of versus the protection of life is our guiding economic principle of Mair (2020). And the spectrum Political and economic alignment by the Rockefeller Foundation (2010).

\section{FIGURE 9 \\ THE FOUR POSSIBLE OUTCOMES. COMBINED MAIR AND ROCKEFELLER FOUNDATION}

\begin{tabular}{|l|l|l|}
\hline & Centralized & Decentralize \\
\hline & $\mathbf{2 . 0}$ & $\mathbf{3 . 0}$ \\
- & $\begin{array}{l}\text { State Capitalism } \\
\text { Lock Step }\end{array}$ & $\begin{array}{l}\text { Barbarism } \\
\text { Hack Attack }\end{array}$ \\
\hline \multirow{2}{*}{} & $\begin{array}{l}\text { State Socialism } \\
\text { Clever Together }\end{array}$ & $\mathbf{5 . 0}$ \\
& & $\begin{array}{l}\text { Mutual Aid } \\
\text { Smart Scramble }\end{array}$ \\
\hline
\end{tabular}

2.0 is a centralized society based on neoliberal principles ruled by a small elite group serving their selfinterest. It is top-down government control and authoritarian leadership with limited innovation and growing citizen pushback. It is the primary and dominant response to the crisis caused by the pandemic. It is an attempt to continue the pre-COVID-19 reality by enacting massive Keynesian stimulus to business. There is high unemployment, and workers fear for their lives and illness.

3.0 is a decentralized society based on neoliberal principles driven by technology where everybody tries to become rich or more affluent. It is an economically unstable society prone to shocks in which government weakens, criminals thrive, and dangerous innovation emerges. This is the bleakest scenario. It is a society focused on seeking profit, and there is no social safety net for the ill and unemployed.

4.0 is the society of the $4^{\text {th }}$ industrial revolution. It is driven by technology and data that strives to solve societal problems. It is a highly coordinated society from which successful strategies emerge to address urgent and deep-seated world issues. In this scenario, there is a shift away from the focus on profit and toward people. The state steps in and gets services that are essential for life from the market domain. 
Hospitals are nationalized. Food, energy, shelter, and internet access are guaranteed, while a universal basic income is part of the policy mix.

5.0 is a society where people are served by technology (Goede, 2020). Technology is employed to solve societal problems but not at the expense of people. It is a society that does not primarily focus on the economy but where individuals and communities develop localized solutions to a growing set of problems. This is not a profit-centered society but a people-focused society where the state does not takes a central role. Rather individuals and small groups begin to organize support and care within their communities. New democratic structures emerge. Some call it the post-growth economy (Hickel, 2020).

The outcomes differ in each country based on their history and leadership.

\section{CONCLUSIONS}

The pandemic exposed systemic errors in all areas, from the world order and the economy to the delivery of health care and how families function. Returning to normal is not an option. The crisis accelerated many trends. The centrum of power shifted from the West to the East. Countries started to think more local again, especially regarding supply chains and food security. The role of government increased. Digitalization was furthered. Social distancing, remote functioning became the new normal. Traveling has decreased and must change completely. The real essential workers were revealed. Cities changed. Pedestrians and bike riders became more common.

There will be a rebirth of the patriotic honor of working for the government. New civic federalism will emerge. "We might well find that success came in states where government, civic and private-sector leaders joined their strengths together in a spirit of self-sacrifice for the common good." (Coronavirus Will Change the World Permanently. Here's How, 2020)

According to Bregman, change beyond the coming out of the lockdown will or has evolved thoughts like this,

Changing the world is a thankless task. There's no moment of triumph when your adversaries humbly acknowledge you were right. In politics, the best you can hope for is plagiarism. Friedman had already grasped this in 1970 when he described to a journalist how his ideas would conquer the world. It would play out in four acts:

"Act I: The views of crackpots like myself are avoided.

Act II: The defenders of the orthodox faith become uncomfortable because the ideas seem to have an element of truth.

Act II: People say, 'We all know that this is an impractical and theoretically extreme view - but of course, we have to look at more moderate ways to move in this direction.'

Act IV: Opponents convert my ideas into untenable caricatures so that they can move over and occupy the ground where I formerly stood. (Bregman, Is de tijd voor een gegarandeerd basisinkomen nu gekomen? , 2020)

Kate Whiting summarized it as follows: There will be a green economic reset and also a reset of work. The future will be greener. There will be a better balance between Planet, People, and Profit. To achieve and maintain this balance, the public sector will fulfill an essential role (Whiting, 2020).

To conclude, experts warn that a worse pandemic will manifest if we do not start taking better care of nature. "Pandemics like COVID-19 could occur more frequently unless we stop rapidly destroying nature, a group of biodiversity experts has warned. 1.7 million unidentified viruses, known to infect humans, are estimated to exist in mammals and water birds. Rampant deforestation, agricultural expansion, and infrastructure development bring us closer to catching them." (Davidson, 2020). 
Others have also pointed out that millions of viruses in the melting ice caps are constantly being exposed, and experts believe that protecting nature is the best way to prevent future pandemics (Sala, 2020).

\section{REFERENCES}

Abdullah, Z. (2020, April 19). COVID-19 pandemic highlights importance of strengthening Singapore's food security, say experts. Retrieved from https://www.channelnewsasia.com/news/singapore/covid10-singapore-food-security-farminginnovation12649468?cid=fbcna\&fbclid=IwAR2xlba9498WnGTJf5KF4zwJtZ86ey43J1EjunLEt5FQvOMEl dBNghARrkI

Abrams, A. (2020, March 19). Total Cost of Her COVID-19 Treatment: \$34, 927.43. Retrieved from https://time.com/5806312/coronavirus-treatmentcost/?utm_source=facebook\&utm_medium $=$ social\&utm_campaign=editorial\&utm_term $=$ health_ covid-

19\&linkId=84678294\&fbclid=IwAR1VF_r5scXROCmvZboPF08BudTV5W1EmyvQj01sA3L_ys DB09UxIy3LScE

Again, T.C. (2020, May 8). Aria Bendix. Retrieved from https://www.businessinsider.com/cities-are-overagain-coronavirus-2020-

5? fbclid=IwAR2P LFhGotx56wSZtYw80WkaWuzW9KUco2gwgbO8Q2Lrct48cw8CwoCaFY

Bachelet, M. (2020, April 15). Our Health Depends on Each Other. That's Why We Need To Fight This

Threat Together. Retrieved from https://time.com/collection/finding-hope-coronaviruspandemic/5820652/michelle-bachelet-fight-coronavirus-

together/?utm source $=$ facebook\&utm medium $=$ social\&utm campaign=editorial\&utm term $=$ co vid-19\&linkI $\bar{d}=86736629 \&$ fbclid $=$ IwAR2nJGE4CI4RqCyYALmqoXopywgeeblLWY

Bakan, J. (2005). The Corporation: The Pathological Pursuit of Profit and Power.

Banerjee, A., \& Duflo, E. (2020, May 26). Abhijit Banerjee and Esther Duflo on how economies can rebound. Retrieved from https://www.economist.com/by-invitation/2020/05/26/abhijit-banerjeeand-esther-duflo-on-how-economies-can-

rebound? $\mathrm{fsrc}=\mathrm{scn} / \mathrm{fb} / \mathrm{te} / \mathrm{bl} / \mathrm{ed} /$ theworldaftercovid19abhijitbanerjeeandestherdufloonhoweconomies canreboundbyinvitation\&fbclid=IwAR3SqcBTUnJm7ujlR2RwF4q-X

Beckman, K. (2020, April 18). Als we nu niet stoppen met lockdown, zijn we onze vrijheid kwijt.

Retrieved from https://www.wyniasweek.nl/als-we-nu-niet-stoppen-met-lockdown-zijn-we-onzevrijheid-kwijt/?fbclid=IwAR0Om1oedAwijIW0nW6xS42r-_hSP9bX7-

CH1vXKOCdNGkgyYdZvI_2xU6w

Berger, M. (2020, May 14). Will the coronavirus pandemic open the door to a four-day workweek? Retrieved from https://www.washingtonpost.com/world/2020/05/24/will-coronavirus-pandemicopen-door-four-day-workweek/?fbclid=IwAR06nZ9a6ozVRK5FojobLkrcAW42hUjFmTRRzcH20oM-t64S-Zbntie8JU

Bloomberg. (2020, June 17). China to Waive Some African Loan Payments Due This Year, Xi Says. Retrieved from https://www.bloomberg.com/news/articles/2020-06-17/china-to-waive-someafrican-loan-payments-due-this-year-xisays?utm_medium $=$ social\&utm_source $=$ facebook\&utm_content $=$ business \&cmpid=socialflowfacebook-business\&utm_campaign $=$ socialflow-organic \&fbclid $=$ IwAR3vM

Bloomberg News. (2020, May 12). What Our Post-Pandemic Future Looks Like. Retrieved from https://www.bloomberg.com/features/2020-future-after-coronavirus/

Bloomberg News. (2020, May 18). China's Xi says supports WHO probe, pledges US\$2 billion to deal with COVID-19. Retrieved from https://www.channelnewsasia.com/news/asia/covid-19-chinapledge-2-billion-who-12746332?cid=FBcna\&fbclid=IwAR1sJulFiGt1BtEdkGjF8RidQDwMGCP15-EscHr_ifZ22UXxpKZQ6yuM3I 
Boffey, D. (2020, April 8). Amsterdam to embrace 'doughnut' model to mend post-coronavirus economy. Retrieved from https://www.theguardian.com/world/2020/apr/08/amsterdam-doughnut-modelmend-post-coronaviruseconomy?fbclid=IwAR0VPM3chP1iuP6Pe6XzCRUbHRkXOW9mU7bOSrkgSbb6oMvypz4j8vcRuo

Bogosavac, N. (2020, May 5). Is de bodem bereikt? Misschien wel, zeggen deze economen. Retrieved from https://nos.nl/collectie/13824/artikel/2332889-is-de-bodem-bereikt-misschien-wel-zeggendeze-economen

Bostock, B. (2020, April 28). Denmark and Poland are refusing to bail out companies registered in offshore tax havens. Retrieved from https://www.businessinsider.com/coronavirus-companiestax-havens-banned-denmark-poland-bailout-2020-4?utm_medium=social\&utm_campaign=sfinsider-main\&utm_source=facebook.com\&fbclid=IwAR0Yb-q-UVS6PT j3trO0oHRM2XpvQ4ffoc1Jvk7rfRWaNJxE7askr2TQA

Bowler, J. (2020, March 30). The COVID-19 Virus May Have Been in Humans For Years, Study Suggests. Retrieved from https://www.sciencealert.com/the-new-coronavirus-could-have-beenpercolating-innocently-in-humans-foryears?fbclid=IwAR25a538pbHGuVxr08eQOSx7jR1NsXUnFPdvNw_dbKKBjikZGn3siRKSRjc

Bregman, R. (2020, April 2). Is de tijd voor een gegarandeerd basisinkomen nu gekomen? Retrieved from https://decorrespondent.nl/9731/is-de-tijd-voor-een-gegarandeerd-basisinkomen-nugekomen/374108295-e11678d8?fbclid=IwAR04r1oRVg5qap2Ryr9exmO5bxNOgp3 osSGyBTfJArMcm2M1y--3emSBY

Bregman, $\bar{R}$. (2020, May 14). The neoliberal era is ending. What comes next? Retrieved from $\mathrm{https}$ ://thecorrespondent.com/466/the-neoliberal-era-is-ending-what-comes-next/61655148676a00ee89a?fbclid=IwAR1IbSxolWk3GWRj5dfejQ5CvlkfANYt1UKZvZqcO9GXqRiu3AlMyHCC68

Briggs, H. (2020, March 26). Coronavirus: Pangolins found to carry related viruses. Retrieved from https://www.bbc.com/news/science-environment52048195 ?at_custom $2=$ facebook_page\&at_campaign $=64 \&$ at_custom $1=\% 5$ Bpost + type $\% 5$ D\&at medium $=$ custom7\&at_custom4=14E0B20C-6F50-11EA-A4232C9DFCA12A29\&at_custom3=BBC+News\&fbclid=IwAR2KBUtR7lalfxJMI_1hzgfPc6talbzk1 E90Wyv

Broom, D. (2020, April 3). Homeschooling during the coronavirus pandemic could change education forever, says the OECD. Retrieved from https://www.weforum.org/agenda/2020/04/coronavirushomeschooling-technology-oecd?fbclid=IwAR0zr6KULL6rex6KGH_OobxZsCJKTPzfYcWoq9GjpZNyYvB4iJ64r7YQeo

Campbell, C. (2020, March 26). Agriculture Sector Will Serve As A Lifeline Against COVID-19. Retrieved from https://nationwideradiojm.com/agriculture-sector-will-serve-as-a-lifeline-againstcovid-19-pandemicholness/?fbclid=IwAR0NNwyFTgNG6MYbvJKrLYqwo0KO_5C4jpN5YTWT7jdRXf0zfOcfVn bVILo

Carney, M. (2020, April 16). Mark Carney on how the economy must yield to human values. Retrieved from https://www.economist.com/by-invitation/2020/04/16/mark-carney-on-how-the-economymust-yield-to-human-values

Carrington, D. (2020, April 29). Halt destruction of nature or suffer even worse pandemics, say world's top scientists. Retrieved from https:/www.theguardian.com/world/2020/apr/27/halt-destructionnature-worse-pandemics-topscientists?CMP=fb_gu\&utm_medium=Social\&utm_source=Facebook\&fbclid=IwAR1Iljh3gogbS ifTuxcwAeXwcG5liKaSmL7RNVsV6PWLVsLPGVPEbKcpJb0\#Echobox=1587982626

Channel News Asia. (2020, March 26). COVID-19 pandemic highlights 'need for more cooperation between countries, not less': PM Lee. Retrieved from https://www.channelnewsasia.com/news/singapore/covid-19-pandemic-more-cooperation- 
countries-lee-hsien-loong-

12580214?cid=FBcnaThe\&fbclid=IwAR1iOpeHbONLOy_uFDqYX1LxNfI_bjx8vZGBz6fAufC dDnuGeeHhfUTVV2E

Channel News Asia. (2020, April 17). Tens of thousands defy Bangladesh lockdown for imam's funeral. Retrieved from https://www.channelnewsasia.com/news/asia/thousands-defy-bangladeshlockdown-imam-funeral-covid-19-12655558?cid=FBcna\&fbclid=IwAR28XSjTG96F1b6a8PzSku7jRUOhu7r8miAYp8Ts8frEUVWJEBFSODTeNI

Channel News Asia. (2020, April 18). Director of Wuhan lab denies COVID-19 link. Retrieved from https:/www.channelnewsasia.com/news/asia/director-of-wuhan-lab-denies-covid-19-virus-linkchina- 12656530

Channel News Asia. (2020, April 19). Trump warns China could face 'consequences' over COVID-19 pandemic. Retrieved from https://www.channelnewsasia.com/news/asia/covid19-trump-warnschina-consequences-pandemic-12656302?cid=h3_referral_inarticlelinks_24082018_cna

Channel News Asia. (2020, April 26). COVID-19: Parliament could meet from multiple locations under proposed law. Retrieved from https://www.channelnewsasia.com/news/singapore/covid-19parliament-meeting-bill-continuity-arrangements12680966? cid=FBcna\&fbclid=IwAR3JrYRZMiwI3W6Pj4PrVfog1e2bTqPkD10ZzuIVzAkWRDKQhnpkg_s5A0

Channel News Asia. (2020, April 28). Ook zo'n zin om te feesten? Deze club heeft een Autodisco. Retrieved from https://www.channelnewsasia.com/news/lifestyle/oscars-streaming-films-covid19-movies-netflix-hollywood-12686050?cid=FBcna\&fbclid=IwAR3shDkhX605hUVNyTLAU3_94c23qy9hxfLtP3j_h2V0ZOVnVhaqWvjeKY

Channel News Asia. (2020, May 14). Lessons from around the world: How schools are opening up after COVID-19 lockdowns. Retrieved from https://www.channelnewsasia.com/news/world/covid-19schools-reopening-lockdown-us-coronavirus-

12729520?cid=FBcna\&fbclid=IwAR0s13oLiu4YDgAianUrDEudAAnrb6Zr_dYdnmMelMOaBz C8ocrcxu6_T6k

Channel News Asia. (2020, May 14). 22\% increase in family violence reports since start of circuit breaker period. Retrieved from https://www.channelnewsasia.com/news/singapore/familyviolence-domestic-abuse-police-reports-circuit-breaker-12731056? cid=FBcna\&fbclid=IwAR35KT3jiLq5KBfSXvrol7ORkfTa2jnai13e6vN67AaK0ROZhmYWZioM2I

Channel News Asia. (2020, May 15). London streets to go car-free to encourage walking and cycling amid COVID-19 social distancing restrictions. Retrieved from https://www.channelnewsasia.com/news/world/covid19-london-streets-car-free-walking-cyclingpublic-transport-12737094?cid=FBcna\&fbclid=IwAR0LyoqiGdEHV82p3uqIF3CbzdqWAcgTsbsawE7iIHmN76eExiTPxFn3fo

Channel News Asia. (2020, May 18). UN says COVID-19 is 'wake-up call' for the world. Retrieved from https:/www.channelnewsasia.com/news/world/un-antonio-guterres-covid-19-pandemic-wake-upcall-for-the-world12746380?cid=FBcna\&fbclid=IwAR2AEs6WMup3HgLyrURYNQZrS3zAKeTwVa_1D491Q11UAqV0rTbilnIDUI

Channel News Asia. (2020, May 31). People more important than the economy, Pope says about COVID19 crisis. Retrieved from https:/www.channelnewsasia.com/news/world/people-more-importantthan-the-economy-pope-covid1912789152?cid=fbcna\&fbclid=IwAR0MM7SGJqq2ovAZKTjjzfMIi--LFgsu-9ZJDtN6BdKC6MA4-K01zV8MiQ

Channel News Asia. (2020, June 22). COVID-19 pandemic still accelerating: WHO chief. Retrieved from https:/www.channelnewsasia.com/news/world/covid-19-pandemic-still-accelerating-who-chief12859262

Clenfield, J. (2020, April 13). Goldman Sees Advanced Economies Shrinking 35\% Amid Pandemic. Retrieved from https://www.bloomberg.com/news/articles/2020-04-14/goldman-sees-advanced- 
economies-shrinking-35-amid-pandemic?utm_campaign=socialflow-

organic\&utm_medium=social\&cmpid=socialflow-facebook-

business\&utm_content $=$ business\&utm_source $=$ facebook\&fbclid $=$ IwAR $1 \mathrm{dbfIrLZ}$

CNA Lifestyle. (2020, April 14). Home-based learning: Harvard University is offering 67 free online courses. Retrieved from https://cnalifestyle.channelnewsasia.com/trending/home-based-learningfree-online-courses-harvard-university-

12639024?cid=FBcna\&fbclid=IwAR2jcMpjnYp4C6YeWwyqiLwfvfGbmzgDAa41ClXiFiAyhK B_pIcTYsjKcuk

Cosslett, R.L. (2020, June 17). Coronavirus hasn't gone away. So why are people acting as if it has? Retrieved from https://www.theguardian.com/commentisfree/2020/jun/17/coronavirus-englandlockdown-shops-parks-social-

distancing?CMP=fb_gu\&utm_medium=Social\&utm_source=Facebook\&fbclid=IwAR1Q96dXOf cCqO0SSF55wwgeK1MrzLjU6whFL0NZpGqoBx4210FpK80SRT0\#Echobox=1592387181

Cotroneo, C. (2020, April 28). New Zealand calls for thousands of new 'green' jobs in bold comeback plan. Retrieved from https://www.mnn.com/earth-matters/wilderness-resources/stories/newzealand-recovery-plan-green-party-economycoronavirus? fbclid=IwAR3oyC7yjWiDzjkU6mNN3hJABTGo6r-PCwjVgRw3h8idHjXafMPwrUV4bg

Crabtree, J. (2020, May 3). The End of Emerging Markets? Retrieved from $\mathrm{https}$ ://foreignpolicy.com/2020/05/03/emerging-markets-coronavirus-pandemic-economicfallout/?fbclid=IwAR21oGEa0MvKCrGebBmb8UXMhRw2SdaQ0qAe916PpTS1TATgvkcDND mN5ZA

Crabtree, J., Kaplan, R., Crabtree, J., Kaplan, R.D., Muggah, R., Naidoo, K., . . Wrage, A. (2020, May 16). How the Coronavirus Pandemic Will Permanently Expand Government Powers. Foreign Policy Magazine.

Cripps, K. (2020, April 16). Airline passengers undergo Covid-19 blood tests before boarding. Retrieved from https://edition.cnn.com/travel/article/emirates-passengers-blood-test-covid-

19/index.html?utm_source=fbCNN\&utm_medium $=$ social\&utm_term=link\&utm_content $=2020$ 04-18T03\%3A00\%3A11\&fbclid=IwAR3TXbZZsHGxPg1dg0TiApdZwnEyRQLNUz5A0j4KgPJ8qsxVdX7HyKFlAY\&fbclid=IwAR

Czerny, S. (2020, May 22). Why we need social sciences and the humanities to live with Covid-19. Retrieved from https://www.coronatimes.net/why-social-sciences-humanities-covid19/?fbclid=IwAR1RNgNcz04UK2Fdy-1LiMg1H77B4rMIjz7pPkK2UYihc2mCdIb_b7HqFak

Dams, T. (2020, May 3). Pandemie zal opmars van China niet stuiten, maar juist versnellen. Retrieved from https://www.ad.nl/buitenland/pandemie-zal-opmars-van-china-niet-stuiten-maar-juistversnellen a6f0aa73/?fbclid=IwAR26cIp4R0ovZhDYdei1Sw5XZthmqfUpbHLnOUnNsVcDKi0VDrHHiXXxDI

Davidson, J. (2020, May 4). Scientists warn worse pandemics are on the way if we don't protect nature. Retrieved from https://www.weforum.org/agenda/2020/05/scientists-pandemics-coronavirusnature-covid19-health?fbclid=IwAR2k9WMmhcvxuFVr01wJ5RkW1p5TfTBnf8cK2mU3A7AH6TYhbtz83RNDa0

de Rooij, J. (2020, April). Coronacrisis: dit mag je werkgever wel en niet van je vragen. Retrieved from https://www.ad.nl/binnenland/deskundigen-waarschuwen-dat-coronacrisis-kan-leiden-tot-angstendepressie a7ab8245/?fbclid=IwAR3ei6cGAXoQGBRbCtyDiZyi7_oaOygE3vKBASpc8avBKPtS 5ZwZFvAm4bA

Dewan, A., Pettersson, H., \& Croker, N. (2020, April 16). As governments fumbled their coronavirus response, these four got it right. Here's how. Retrieved from https://edition.cnn.com/2020/04/16/world/coronavirus-response-lessons-learnedintl/index.html?fbclid=IwAR0LvORdjWSjfXsolJ-5vqdaIFvX9tBsX34JUQAq5OWORsnr6KkF8THz0Q 
Dodelijke combinatie van vochtigheid en hitte neemt wereldwijd toe. (2020, May 12). Retrieved from www.nu.nl: https://www.nu.nl/klimaat/6050823/dodelijke-combinatie-van-vochtigheid-en-hitteneemt-wereldwijd-toe.html

Doherty, A. (2020, May 16). Has the coronavirus crisis killed neoliberalism? Don't bet on it. Retrieved from https://www.theguardian.com/commentisfree/2020/may/16/state-intervention-agenda-dontassume-neoliberalismdead?fbclid=IwAR1dxNx9PgdB7Rb3cDUuaKZz4k1E1Y1pSRUkzhx6DvRLAGGvW2m_WkB_ $8 \mathrm{pg}$

Doorduin, T. (2020, May 25). RISICOGROEPEN WORDEN NIET 'BESCHERMD', MAAR

BUITENGESLOTEN. Retrieved from https://www.oneworld.n1/lezen/opinie/risicogroepenworden-niet-beschermd-maar-

buitengesloten/?utm_content=buffer6955f\&utm_medium $=$ social\&utm_source=facebook\&utm_c ampaign=buffer\&fbclid=IwAR2RIRHMpoR12STQcptdv_A863U6Y1vXgLQTOpnzgCnNm2S0 Xo-NBNUkZY

Doudna, J. (2020, June 5). Jennifer Doudna on how covid-19 is spurring science to accelerate. Retrieved from https://www.economist.com/by-invitation/2020/06/05/jennifer-doudna-on-how-covid-19-isspurring-science-to-

accelerate? $\mathrm{fsrc}=\mathrm{scn} / \mathrm{fb} / \mathrm{te} / \mathrm{bl} / \mathrm{ed} /$ theworldaftercovid19jenniferdoudnaonhowcovid19isspurringscien cetoacceleratebyinvitation\&fbclid=IwAR1QYFbACouaxyl-Z_De

Drayer, D. (2020, June 10). Groot openluchtbordeel Curaçao sluit na 71 jaar, maar voor hoelang? Retrieved from https://nos.nl/artikel/2336831-groot-openluchtbordeel-curacao-sluit-na-71-jaarmaar-voor-hoelang.html

Dunk, T.V. (2020, May 3). Opinie: Onze elite is walgelijk zelfzuchtig. Retrieved from https://www.volkskrant.nl/columns-opinie/opinie-onze-elite-is-walgelijk-

zelfzuchtig $\sim$ be214a2e/?utm_campaign=shared_earned\&utm_medium=social\&utm_source=faceb ook

Engelen, E. (2020, April 1). MBA-debacle. Retrieved from https://www.groene.n1/artikel/mbadebacle?fbclid=IwAR0r3k8pQ7NpX_qxXfRzccOfKukjiObF1Yf9UHnYKq_uTztJzGEmjrtQRag

Fabian, J., Jacobs, J., \& Marlow, I. (2020, May 3). Trump Promises 'Conclusive' U.S. Report on Virus's China Origins. Retrieved from https://www.bloomberg.com/news/articles/2020-05-03/pompeosays-enormous-evidence-links-virus-to-wuhanlaboratory?utm_source=facebook\&utm_campaign=socialfloworganic\&utm_content=business\&utm_medium=social\&cmpid=socialflow-facebookbusiness \& fbclid=IwAR2Rshc

Facebook. (2020, March). La verdad oculta del coronavirus. Retrieved March 25, 2020, from $\mathrm{https}$ ://www.facebook.com/100807208228869/videos/742276039637677/?v=742276039637677

Fontaine, R. (2020, April 17). Globalization Trade War After Coronavirus Pandemic. Retrieved from https://foreignpolicy.com/2020/04/17/globalization-trade-war-after-coronaviruspandemic/?fbclid=IwAR0r51ZI6XxWhFzjlbMpbkTDYdpgqTAE5za6TnwIzzPziukQysFPalzt-3A

Foster, B. (2020, May 24). Let science lead: We need more leaders with science backgrounds. Retrieved from https://thehill.com/opinion/healthcare/497533-let-science-lead-we-need-more-leaders-withscience-backgrounds

Fracalossi de Moraes, R. (2020, March 20). In Practice, there are Two Pandemics: One for the Well-Off and One for the Poor. Retrieved from

https://www.globalpolicyjournal.com/blog/20/03/2020/practice-there-are-two-pandemics-onewell-and-one-poor

Frey, I. (2020, March 19). "Herd Immunity" is Epidemiological Neoliberalism. Retrieved from https://thequarantimes.wordpress.com/2020/03/19/herd-immunity-is-epidemiologicalneoliberalism/?fbclid=IwAR3tRGOM3gSM5Ai_at8rvhBeJVjvOZiH1125I6_r-tbtA23FoOUTG5VjTI 
Friedman, U. (2020, April 19). New Zealand's Prime Minister May Be the Most Effective Leader on the Planet. Retrieved from https://www.theatlantic.com/politics/archive/2020/04/jacinda-ardern-newzealand-leadership-coronavirus/610237/?utm_term=2020-04-

$19 \mathrm{~T} 12 \% 253 \mathrm{~A} 00 \% 253 \mathrm{~A} 08 \& u t m \_$campaign $=$the-

atlantic\&utm_source=facebook\&utm_content $=$ edit-

promo\&utm_medium $=$ social\& fbclid=IwAR0 $\mathrm{wMbm} 77$ of

Fukuyama, F. (2020). The Pandemic and Political Order; It Takes a State. Retrieved from https://wwwforeignaffairs-com.cdn.ampproject.org/c/s/www.foreignaffairs.com/articles/world/2020-0609/pandemic-and-politicalorder?amp\&fbclid=IwAR3Gb8W_eLew5BC3VjcmIBc44zJ_3wglktPBqPLgYy7_XQBOBwjcaj5 AhfU

Fund, J., \& Hay, J. (2020, April 13). Has Sweden Found the Right Solution to the Coronavirus? Retrieved from https://www.nationalreview.com/2020/04/coronavirus-response-sweden-avoids-isolationeconomic-

ruin/?fbclid=IwAR1d7d2FiIq9wI0Ar3sTFlEWC5LvCGMRzOAoEtwVpYXamRJ6nW7JmsmbRt $\mathrm{M}$

Gambuto, J.V. (2020, April 10). Prepare for the Ultimate Gaslighting. Retrieved from https://forge.medium.com/prepare-for-the-ultimate-gaslighting-6a8ce3f0a0e0

Garside, J., \& Neate, R. (20202, May 4). UK government 'using pandemic to transfer NHS duties to private sector'. Retrieved from https://www.theguardian.com/business/2020/may/04/ukgovernment-using-crisis-to-transfer-nhs-duties-to-privatesector?CMP $=\mathrm{fb}$ gu\&utm_medium $=$ Social\&utm_source $=$ Facebook\&fbclid $=$ IwAR00qkSw758L7 9IpPC6ShA6MmTDmY4we-5nky3W2MsHEVAp293vgphVYTbI\#Echobox=1588663260

Gavi. (2020, May 18). The Future with COVID-19: Three Potential Scenarios. Retrieved from https://www.gavi.org/vaccineswork/future-covid-19-three-potentialscenarios?fbclid=IwAR2rJVugXcGORvj1cywFWSA9bkCO3UP-rm8QmTEbjaEcgARZ12tSLGmydw

Ghosh, J. (2020, April 28). The Argentina Debt Reduction Proposal. Retrieved from $\mathrm{https}$ ://www.ineteconomics.org/perspectives/blog/the-argentina-debt-reductionproposal?fbclid=IwAR1Eu5hX_yW7TKJ6ceuqdN-8f9O1PNE1kiOxla4fdbEithpSSLfmHIXfKhE

Giesen, P. (2020, May 10). Sociale druk op miljardairs neemt toe: draag bij aan herstel. Retrieved from https://www.volkskrant.nl/nieuws-achtergrond/sociale-druk-op-miljardairs-neemt-toe-draag-bijaanherstel ba3165f4/?fbclid=IwAR2IQw_ssFzvFiau_wdey191KxkwUAbOgvQ7SdQZJrL0juCq0B Ti87BDieY

Gleiser, M. (2020, March 29). Covid-19 will change us as a species. Retrieved from https://edition.cnn.com/2020/03/26/opinions/covid-19-will-change-us-as-a-speciesgleiser/index.html

Goede, M. (2020). Society 5.0; We and I. Willemstad: University of Governance 5.0 / Goede 5.0 / Think Thank 5.0.

Gravemaker, R. (2020, April 24). Geeft de crisis je stiekem rust? Je bent niet de enige. Retrieved from https://www.vpro.nl/programmas/tegenlicht/lees/artikelen/2020/zo-zorgt-de-corona-crisis-voorrust-in-je-hoofd.html?fbclid=IwAR2W7ScUH0o3GkdWNNwjvbwS-

DKTa89HQDijEYM1CrVJSY3UJzRaxkISZjA

Greiff, J. (2020, April 14). The Great Recession Was Bad. The 'Great Lockdown' Is Worse. Retrieved from https://www.bloomberg.com/opinion/articles/2020-04-14/global-great-lockdown-willdwarf-the-great-recession?utm_campaign $=$ socialfloworganic\&utm_medium=social $\& \mathrm{cmpid}=$ socialflow-facebookbusiness\&utm_content $=$ business\&utm_source $=$ facebook\&fbclid $=$ IwAR36hOY2KPw33

Grothaus, M. (2020, May 5). What pandemic? Carnival Cruise bookings soar 600\% for August trips. Retrieved from https://www.fastcompany.com/90503385/what-pandemic-carnival-cruise- 
bookings-soar-600-for-august-

trips?fbclid=IwAR2kpe91sC5eGHJM0_kpM_uD5kbj_ZbVcCIuGoFGPsRGp4zbhC6_oO518vg

Guina, R. (2020, April 22). Stimulus Proposal: $\$ 2,000$ Payment Plus \$1,000 Per Month Until $\overline{1}$ Year

After Crisis Ends. Retrieved from https:/www.forbes.com/sites/ryanguina/2020/04/22/stimulusproposal-2000-payment-plus-1000-per-month-until-1-year-after-crisis-ends/?fbclid=IwAR3uD-

Me2fksAXfOYSBGNRUN8S3chR6WGaaWpNss4OB7gvK3tCBIDUAe4e0\#60e2a2cc6fa5

Haag, M. (2020, May 12). Manhattan Faces a Reckoning if Working From Home Becomes the Norm.

Retrieved from https://www.nytimes.com/2020/05/12/nyregion/coronavirus-work-from-

home.html?smid=fb-

nytimes\&smtyp=cur\&fbclid=IwAR0nVC4PGHqbTbkMBTOsNNiiVB108WqMeMY5SrRtjtYmEj3nw7q7WHELGw

Harari, Y.N. (2020, March 20). Yuval Noah Harari: The world after coronavirus. Retrieved from https://www.ft.com/content/19d90308-6858-11ea-a3c9-1 fe6fedcca75

Harvey, B., Kog, K., Heijmans, P., Martin, P., Speciale, A., \& Follain, J. (2020, March 13). Scoring

World Leaders' Response to the Coronavirus Outbreak. Retrieved from

https://www.bloomberg.com/news/articles/2020-03-13/how-world-leaders-responded-to-the-

coronavirus-

outbreak?utm_source $=$ facebook\&utm_medium $=$ cpc\&utm_campaign $=488523$ _USAll\&kwp_0 $=1$

605672\&fbclid=IwAR2cefGpM1B5MqroBO5o9-

t2RfCqP68LsEbJ_1SrKPioFl_SwDDuGKeu7Y

Harvey, F. (2020, April 21). Coronavirus crisis could double number of people suffering acute hunger UN. Retrieved from https://www.theguardian.com/world/2020/apr/21/global-hunger-could-benext-big-impact-of-coronavirus-pandemic?CMP=share btn_fb\&fbclid=IwAR0qWpSUOxHPqspIHQ5N5JHFw0jZDN-alhwDX202DxR aMUfITmDwlozwY

Henley, J. (2020, May 7). Finnish basic income pilot improved wellbeing, study finds. Retrieved from https://www.theguardian.com/society/2020/may/07/finnish-basic-income-pilot-improvedwellbeing-study-finds-coronavirus?CMP=share_btn_fb\&fbclid=IwAR2fgg-rJvustXfX1pWcGqe5o0qc7JxZfZ8YSFf7MknDJ5sHlyIwa_LE3A

Hens, T. (2020, April 4). Het goede nieuws: Er is een plan voor een betere wereld. Retrieved from https://www.mo.be/interview/het-goede-nieuws-er-een-plan-voor-een-betere-wereld

Hickel, J. (2020, March 30). Het is nú tijd voor een economie die niet draait om groei en koopkrachtplaatjes. Retrieved from https://decorrespondent.n1/10594/het-is-nu-tijd-voor-eeneconomie-die-niet-draait-om-groei-en-koopkrachtplaatjes/16959674305420-

503698f4? fbclid=IwAR3Kr5-Lsj06-

IoNsLrKdSFXBM_R0uwFWieYBGAtDpP4mxOhDuMHVnueV3w

Hiller, S. (2020, May 21). COVID-19 Sparks a Rebirth of the Local Farm Movement. Retrieved from https://www.yesmagazine.org/environment/2020/05/21/coronavirus-food-local-farmmovement/?fbclid=IwAR2JJ2nyirkT_YooLH64vf9x05Mn3CRC8nlK8TGBxwton_sZfYqWYLy 8-Qo

Hirsch, A. (2020, May 21). Why are Africa's coronavirus successes being overlooked? Retrieved from https://www.theguardian.com/commentisfree/2020/may/21/africa-coronavirus-successesinnovation-europeus?CMP=fb_gu\&utm_medium=Social\&utm_source=Facebook\&fbclid=IwAR33DLLpsFgG_0n3 UwrSQ-miy-DxKNX3GNHH5pG_SC08N-gl1pLign2DeI4\#Echobox=1590782418

Holthaus, E. (2020, April 1). We aren't just stopping coronavirus. We're building a new world . Retrieved from https://thecorrespondent.com/385/we-arent-just-stopping-coronavirus-werebuilding-a-new-world/50968856015625b9768?fbclid=IwAR03ZMi3fjTyPiq1UAGM6AjGs1 rccCOJm7VrJvoNzCN8PoY50AOBfT WN3tk

Hong Fincher, L. (2020, April 15). Women leaders are doing a disproportionately great job at handling the pandemic. So why aren't there more of them? Retrieved from 
https://edition.cnn.com/2020/04/14/asia/women-government-leaders-coronavirus-hnkintl/index.html?utm_content $=2020-04-$

$15 \mathrm{~T} 01 \% 3 \mathrm{~A} 01 \% 3 \mathrm{~A} 13 \& \mathrm{tm} \_$term $=$link\&utm_source $=\mathrm{fbCNNi} \& u t m \_$medium $=$social\&fbclid=IwA R2I6y-VtBLMilvoXLvAdB2_TLJKYjRvI8bTREIdICN9eSI7xm44SLBgibI

Ibrahim, A. (2020, March 23). China's Debt Diplomacy Will Get a Coronavirus Boost. Retrieved from https://foreignpolicy.com/2020/03/23/china-coronavirus-belt-and-road-bri-boost-debtdiplomacy/?fbclid=IwAR0Tts13eTTA0ylJJe18qjs6bR7PYWpQz0VtTxO-K5Ce0Gfic1VqUTJAb0

Icke, D. (2020, March 23). A ONE WORLD GOVERNMENT: How Coronavirus Could End Up Leading To A Centralised Society. Retrieved from

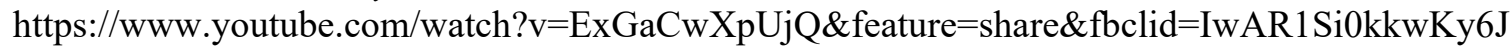
TvbrfYKo-PEthbRRyOeHfGsSEq2A27TNeFSaCbT7ZjGSAk

Jacobs, B. (2020, April 17). Waarom de kapitalistische droom uitdraaide op een illusie. Retrieved from https://www.vn.nl/kapitalistische-droomillusie/?utm_source=facebook.com\&utm_medium $=$ social\&utm_campaign=share\&fbclid=IwAR1 XOcxXowtuUsyYLlzVdO4JPrsJ_KYC9raTmZ2EqKaKI0infa8ND0TXeCk

John, A., Burn, N., Garrett, L., \& Haass, $\bar{R}$. (2020, March 20). How the World Will Look After the Coronavirus Pandemic. Retrieved from https://foreignpolicy.com/2020/03/20/world-order-aftercoroanvirus-pandemic/

Kennedy, S., \& Jamrisko, M. (2020, March 21). V,L or Nike Swoosh? Economist Debate Shape of Global Recovery. Retrieved from https://www.bloomberg.com/news/articles/2020-04-02/economistsdebate-shape-of-a-global-recovery-after-

coronavirus?utm_source $=$ facebook\&utm_medium $=$ cpc\&utm_campaign $=492616$ USAll\&kwp_0 $=1620427 \& \mathrm{fbclid}=\mathrm{IwAR} 0$-vtnqoWb9gwcwZG1xFghoWlbWr5LZmrWzIRaRO20yRwjb_nZK6LLj

Kerstens, $\bar{B}$. (2020, April 13). Meer dan zestig wetenschappers sturen samen brandbrief aan kabinet over corona-app. Retrieved from https://www.ad.nl/binnenland/meer-dan-zestig-wetenschapperssturen-samen-brandbrief-aan-kabinet-over-coronaapp a44c5e2d/?fbclid=IwAR2vXsia42RCEGhggSO41pPutzhxxuW8LVGotWVBpdYU_onldyx RAnQFEWc

Keulemans, M. (2020, June 12). Een vergeten hoofdstuk: De coronacrisis (?) van 1890. Retrieved from https://www.volkskrant.nl/wetenschap/een-vergeten-hoofdstuk-de-coronacrisis-van1890 b0b9facb/?fbclid=IwAR2Z6GcF_AQUxQa_boLqkd2QtH17kbmiUDHJrBMx_YzbIXA9U kmKmOrqlyc\&referer $=\mathrm{https} \% 3 \mathrm{~A} \% 2 \mathrm{~F} \% 2 \mathrm{Fwww}$.facebook.com $\% 2 \mathrm{~F}$

Kieskamp, W. (2020, May 27). CU: In de toekomst alleen noodsteun voor bedrijven die verantwoord ondernemen. Retrieved from

https://myprivacy.dpgmedia.net/?siteKey=w38GrtRHtDg4T8xq\&callbackUrl=https://www.trouw $. \mathrm{nl} /$ privacy-wall/accept?redirectUri $=\% 2$ fa-

b88532fa\%3ffbclid\%3dIwAR2wTyZr9DxWNS1MI58uDfPg5jlgQHXRtYEqvCZLIEQjyC3GLp CzrP9HPE0

King, N. (2020, April 17). Economic Recovery Will Require 'Lessening Of The Wealth Gap, 'Says Hedge Fund Titan. Retrieved from https://www.npr.org/sections/coronavirus-liveupdates/2020/04/16/836155692/economic-recovery-will-require-lessening-of-the-wealth-gapsays-hedge-fund-

titan?utm_source=facebook.com\&utm_term $=$ nprnews\&utm_campaign=npr\&utm_medium $=$ socia $1 \&$ fbclid=IwAR2_zk8KJyPN9U

Kit, T.S. (2020, May 14). COVID-19 drives more wet market stalls online, but will they be here to stay? Retrieved from https://www.channelnewsasia.com/news/singapore/covid-19-more-wet-marketstalls-go-online-delivery12718868?cid=FBcna\&fbclid=IwAR1udch5CK998j4_VO_h3cQrlmV0KbljufZiYwPTI_LfvxPH dJzrTdfZ9wc 
Klein, N. (2007). The Shock Doctrine: The Rise of Disaster Capitalism. Canada: Knopf Canada.

Klein, N. (2020, May 13). How big tech plans to profit from the pandemic. Retrieved from https://www.theguardian.com/news/2020/may/13/naomi-klein-how-big-tech-plans-to-profit-fromcoronavirus-pandemic?CMP=share_btn_fb\&fbclid=IwAR34_bYyY4p_XgDnnuEZco_qeZe1ZMLyYaB6_ZgaypxuqR6IHjKsqAgu4A

Kotoky, A. (2020, March 26). The Airlines Most in Danger of Going Under During the Crisis. Retrieved from https://www.bloomberg.com/news/articles/2020-03-26/the-airlines-most-in-danger-as-virusinflicts-252-billion-

blow?utm_source=facebook\&utm_medium $=$ cpc\&utm_campaign $=492083$ USAll\&kwp_0 $=1617$ 681\&fbclid=IwAR2R7KhhriOaMxwdjeAUWTMaU1_aMGtV2aczOh9-cO6DFtQuMZUIEfP4x

Kretchmer, H. (2020, June 17). We're 'finished' if we don't change after coronavirus, warns naturalist Jane Goodall. World Economic Forum. Retrieved from https://www.weforum.org/agenda/2020/06/jane-goodall-coronavirus-humanity-natural-animalscovid-finished?fbclid=IwAR1ZmbhYhWnaRcp18rkSDmBJTlHOPE0ZtzQiN65CE0HOCMcUmtqcNzI9EY

Kuys, D. (2020, May 1). 6 economische voorstellen voor een betere wereld na corona. Retrieved from https://www.vpro.nl/programmas/tegenlicht/lees/artikelen/2020/6-economische-voorstellenbetere-wereldcorona.html?fbclid=IwAR1k7zPbB5YHxB7OeZ_zuGW2iHmeegVq30tk8LWPL0j1dDpQ1WBIC RgwM34

Kuznia, R. (2020, May 13). Thousands of people want to be exposed to Covid-19 for science. Retrieved from https://amp.cnn.com/cnn/2020/05/13/us/coronavirus-human-challenge-studyinvs/index.html?fbclid=IwAR0UiUdzDv7vWQmN_J4udGSBU--4TPpA7XAt9a146CODCyxPgRXnFOKDls

Lacina, L. (2020, April 14). Prepare for a 'new normal' as lockdown restrictions ease: Monday's COVID19 WHO briefing. Retrieved from https://www.weforum.org/agenda/2020/04/13-april-whobriefing-coronavirus-covid19-lockdown-restrictionsguidance?fbclid=IwAR1rQGBEBBEboYqe7nTUrsus5yGwHHYpy9W6OCtIcQqGeki5YfCYHih Vvvs

Laughland, O., \& Holpuch, A. (2020, May 2). 'We're modern slaves': How meat plant workers became the new frontline in Covid-19 war. Retrieved from https://www.theguardian.com/world/2020/may/02/meat-plant-workers-us-coronaviruswar?CMP=fb_gu\&utm_medium=Social\&utm_source=Facebook\&fbclid=IwAR0Eq6pqvdcRwY xWNjPieoYM_vT8yeZWHIQt2T_V1yUqiBtMOSqeCDoARwE\#Echobox=1588417032

Launspach, T. (2020, April 6). Coronacrisis brengt voor alleenstaanden flinke uitdagingen met zich mee. Retrieved from https://www.ad.nl/ad-werkt/coronacrisis-brengt-voor-alleenstaanden-flinkeuitdagingen-met-zichmee $\sim$ a652bd47/?fbclid=IwAR1WNnZXlsSQNufEW4GgzlJjijQuIsIM1Gu4Z0cKBda75NNvdLr5 hesM3KM

Lederer, E. (2020, May 16). China Goes After U.S. Over More Than \$1 Billion Owed to UN. Retrieved from https://www.bloomberg.com/news/articles/2020-05-16/china-goes-after-us-over-more-than1-billion-owed-to-theun?utm_source $=$ facebook\&utm_medium $=$ cpc\&utm_campaign $=505700 \_U S A 11 \& k w p \_0=165583$ 2\&fbclid $=$ IwAR1awIGjm9dd3rMcN3LL548t-dbaha_VRQhPjCjxF_G_iBYLvUMK1ü1aUBI

Lee, E. (2020, April 11). Retrieved from https://www.facebook.com/photo.php?fbid=2962962877126842\&set=a.540528819370272\&type $=3 \&$ theater

Letzing, J. (2020, June 17). The plight of Peru illustrates the danger of COVID-19 to developing countries. Retrieved from https://www.weforum.org/agenda/2020/06/the-plight-of-peruillustrates-the-danger-of-covid-19-to-developing-countries?fbclid=IwAR1Y_3Ou8e1EMws6eSn5sekZzHPjTkvGj6PRslGC8OCx0TQ6ZkCTyp8bqQ 
Lindhout, S. (2020, May 26). Merkel vreest voor de toekomst van Europa. Retrieved from https://myprivacy.dpgmedia.net/?siteKey=PUBX2BuuZfEPJ6vF\&callbackUrl=https://www.volk skrant.nl/privacy-wall/accept?redirectUri $=\% 2$ fnieuws-achtergrond $\% 2$ fmerkel-vreest-voor-detoekomst-van-europa $\% 7 \mathrm{eb} 079 \mathrm{~b} 78 \mathrm{~b} \% 2 \mathrm{f} \% 3 \mathrm{ffbclid} \% 3 \mathrm{dIwAR} 10 \mathrm{R}-$

KM3aQmYPTFD7inavsyV2apbrU5nsW

Luchtvaart Nieuws.nl. (2020, April 20). Vliegverkeer heropstarten met mondkapjes voor alle passagiers. Retrieved from https://www.luchtvaartnieuws.nl/nieuws/categorie/2/airlines/vliegverkeerheropstarten-met-mondkapjes-voor-alle-passagiers?utm source $=$ dlvr.it\&utm medium=facebook

Macfarlane, L. (2020, April 24). A spectre is haunting the West-the spectre of authoritarian capitalism. Retrieved from https:/www.opendemocracy.net/en/oureconomy/a-spectre-is-haunting-the-westthe-spectre-of-authoritarian-capitalism/?fbclid=IwAR3Ib5kVYvJ0ZZDdJZIOF3-IU4D57R5xc_e9MDOVB81mKm--RmBH2iy8wE

MacKay, G. (2020, March). Editorial cartoon for March 11. Retrieved from https://www.wellandtribune.ca/opinion-story/9892635-editorial-cartoon-for-march-11/

Mahbubani, K. (2020, April 20). The world after Covid-19. Retrieved from https:/www.economist.com/open-future/2020/04/20/by-invitation-kishoremahbubani? $\mathrm{fsrc}=\mathrm{scn} / \mathrm{fb} / \mathrm{te} / \mathrm{bl} / \mathrm{ed} /$ theworldaftercovid19byinvitationkishoremahbubaniopenfuture $\& \mathrm{f}$ bclid=IwAR30rKP-ufieDv5YnwdLswuGeX1rLZuK1U-U4LJiP-0K03iwqsNcgnw4t9k

Mahdawi, A. (2020, April 11). The secret weapon in the fight against corona-virus: Women. Retrieved from https://www.theguardian.com/commentisfree/2020/apr/11/secret-weapon-fight-againstcoronaviruswomen?CMP $=$ fb gu\&utm_medium=Social\&utm_source=Facebook\&fbclid=IwAR2eNxDWv99 KcBCKW6OWA5F0bCZe0o4WSqBu5r4oR8-w9yJmiLyLdYjgbyY\#Echobox=1586616153

Malpass, D. (2020, May 1). May 1, 2020, end of week update: Debt relieffor the world's poorest countries. Retrieved from https://blogs.worldbank.org/voices/may-1-2020-end-week-update-debtrelief-worlds-poorestcountries?cid=ECR_E_NewsletterWeekly_EN_EXT\&deliveryName=DM63224

Manson, M. (2020, April). Surviving the Looming Mental Health Crisis. Retrieved from https://markmanson.net/coronavirus-mental-health-crisis

Martin, E. (2020, April 8). Half a Billion People at Risk of Poverty From Virus Fallout. Retrieved from https://www.bloomberg.com/news/articles/2020-04-09/half-a-billion-people-at-risk-of-povertyfrom-virusfallout?utm_source=facebook\&utm_medium $=$ cpc\&utm_campaign $=494293$ USAll\&kwp_0 $=162$ 5623\&fbclid $=$ IwAR0YWt9HVIn62e-9O3tANspBUcVxrbSYP1_aPXSAgdsVwFSNwviQYTlxq7 BY

Martin, E. (2020, June 18). Students Face $\$ 10$ Trillion in Lost Earnings Due to Pandemic. Retrieved from https://www.bloomberg.com/news/articles/2020-06-18/students-face-10-trillion-in-lost-earningsdue-to-pandemic?utm_content=business\&cmpid=socialflow-facebookbusiness\&utm_source=facebook\&utm_campaign=socialfloworganic\&utm_medium=social\&fbclid=IwAR3MVOSLYE

Mascini, L. (2020, March 30). Investeerder Kees Koolen: 'Coronacrisis leidt tot totale reset van de wereld'. Retrieved from https://www.nu.nl/ondernemen/6041393/investeerder-kees-koolencoronacrisis-leidt-tot-totale-reset-van-de-wereld.html

Matei, A. (2020, April 15). Should passengers return to cruise ships after the pandemic? No. Retrieved from https://www.theguardian.com/commentisfree/2020/apr/14/cruise-ships-coronaviruspassengers-future?CMP=share_btn_fb\&fbclid=IwAR2k3R1iQRipV9N4MXvIB6GxweMBrzjTrgd2j1EcgnnBTgEuYnbOzXpSCU

Mazzucato, M. (2020, March 18). The Covid-19 crisis is a chance to do capitalism differently. Retrieved from https://www.theguardian.com/commentisfree/2020/mar/18/the-covid-19-crisis-is-a-chanceto-do-capitalism- 
differently?CMP $=$ fb_gu\&utm_medium $=$ Social\&utm_source $=$ Facebook\&fbclid $=$ IwAR1JtKI5MJ zsGkdtNz7LFYMzNnaOJ4feWhO8YKaavspT75EwQzE7bcsFNW0\#Echobox=1584546927

McCluskey, M. (2020, May 19). Cambridge University will hold all classes online for the 2020-21 academic year. Retrieved from https://edition.cnn.com/world/live-news/coronavirus-pandemic05-20-20-intl/h_5f261d792d5a5a850e945257fdb27f4a?utm_term=link\&utm_content $=2020-05$ 20T08\%3A30\%3A05\&utm_source=fbCNNi\&utm_medium=social\&fbclid=IwAR0YV2QzUhAT HzrGMlXoKCtpGLc7PIKL4w4MeJhdIGfFm_m4Mm

McLaughlin, T. (2020, May 22). The End of Hong Kong. Retrieved from https://www.theatlantic.com/international/archive/2020/05/china-hong-kong-pandemicautonomy-law-aggression/611983/?utm term $=2020-05$ -

22T14\%3A51\%3A15\&utm_campaign=the-atlantic\&utm_source=facebook\&utm_content=editpromo\&utm medium $=$ social\&fbclid=IwAR3yS6-GtaG

Meredith, S. (2020, May 14). WHO warns it could take up to 5 years before the coronavirus pandemic is under control. Retrieved from https:/www.cnbc.com/2020/05/14/coronavirus-who-warns-itcould-take-up-to-5-years-to-controlpandemic.html?_source=facebook\%7Cmain\&fbclid=IwAR2AiNDu5mchWNJ7jGpNhCEiyrV4 JY08QlzhcXvzBifr_XQvDBG73YZVF2A

Metro Nieus. (2020, April 24). Moeten wij binnenkort een treinreis resereveren? Retrieved from https://www.metronieuws.nl/in-het-nieuws/2020/04/moeten-we-binnenkort-een-treinreisreserveren?fbclid=IwAR0nQEQbQoeG6g3B5a_GqaJ6ygV6cblYL9JgpbMcJmula0L_WgUI162R dM8

Meuleman, L. (2020, June). It takes more than markets: First lessons. Retrieved from $\mathrm{https}$ //www.eca.europa.eu/Lists/ECADocuments/JOURNAL20_02/JOURNAL20_02_EN.pdf

Miller, Lemire, \& Zeke. (2020, June 1). Trump Took Shelter in White House Bunker as Protests Raged. Retrieved from https://www.bloomberg.com/news/articles/2020-06-01/trump-took-shelter-inwhite-house-bunker-as-protests-raged-kaw2ksvj?utm_medium=social\&cmpid=socialflowfacebook-business\&utm_campaign $=$ socialfloworganic\&utm_source=facebook\&utm_content=business\&fbclid=IwA

Min, C.H. (2020, June 7). Contactless service and cleaning robots: Here's what your next travel experience may be like. Retrieved from https://www.channelnewsasia.com/news/singapore/covid19-travel-experience-hotels-contactless-service-

12792376?cid=fbcna\&fbclid=IwAR0J2vRv63kpF9eN5MVB1eAbUKN6DIYrvpPNthTqAbKjy_ WoDpfAU4OpHMY

Monbiot, G. (2020, May 26). Tory privatisation is at the heart of the UK's disastrous coronavirus response. Retrieved from https://www.theguardian.com/commentisfree/2020/may/27/privatisation-uk-disatrouscoronavirus-response-ppe-care-homes-corporate-power-publicpolicy?fbclid=IwAR2HOkxg10F56ykNXtSWQ9BfH4b7u53FQ5x9YKiuLpO8Ccv5HVtb387594 8

Monks, P. (2020, April 20). Here's how lockdowns have improved air quality around the world. Retrieved from https://www.weforum.org/agenda/2020/04/coronavirus-lockdowns-airpollution?fbclid=IwAR0kUF31J1QOjBO54krZs4O0Me1_0OTweaLnBhoiukddI0_1SPGykPwpe Ak

Mudde, T. (2020, April 24). Zoom-moe: Waarom videovergaderen doodvermoeiend is. Retrieved from https://www.volkskrant.nl/wetenschap/zoom-moe-waarom-videovergaderen-doodvermoeiendis $\sim$ bce9d805/?fbclid=IwAR3ytCtMiRheL9c0rmhdHJnkhkUfw449I9fwUrBlylQktlXpQLbOxFni OLc

Nakazawa, K. (2020, April 16). Xi fears Japan-led manufacturing exodus from China. Retrieved from https://asia.nikkei.com/Editor-s-Picks/China-up-close/Xi-fears-Japan-led-manufacturing-exodusfrom-

306 Journal of Applied Business and Economics Vol. 23(3) 2021 
China?fbclid=IwAR2WaBXaV_k3V2Z7uIIPUSr5TwNaj9RKOmRJ6VJIgi9KP9zoHllGw4QDM 08

Neate, R. (2020, March 27). Jeff Bezos sold \$3.4bn of Amazon stock just before Covid-19 collapse. Retrieved from https://www.theguardian.com/business/2020/mar/27/jeff-bezos-sold-34bn-ofamazon-stock-just-before-covid-19-

collapse?CMP $=$ fb_gu\&utm_medium $=$ Social\&utm_source $=$ Facebook\&fbclid=IwAR188MKMoO Bk_RiKRDJfvMrGg0QEax0MW7nXBiYZe8fDN-t4bVtWQ-SZkio\#Echobox=1585342120

Nelson, A. (2020, April 24). Society after Pandemic. Retrieved from https://items.ssrc.org/insights/society-afterpandemic/?fbclid=IwAR22EtJo2yvOodvSwxMDD255DYz4s9PGNXi3P0EP6DfZhbkVjf6iANoI $\mathrm{O} \_\mathrm{w}$

Niemuth, $\overline{\mathrm{N}}$. (2020, April 13). Reality of American capitalism exposed: Millions line up for food aid as pandemic spreads. Retrieved from https:/www.wsws.org/en/articles/2020/04/13/persa13.html?fbclid=IwAR10wRGgXo2QiyB7x-TFZwdRP9KsQCc7sj55jBoy$3 \mathrm{AMiFzJkkbFkX8hV3 \textrm {s }}$

Nieuwenhuis, M. (2020, June 6). Aantal coronapatiënten groeit wereldwijd harder dan ooit: 'De pandemie is nog volop gaande'. Retrieved from https://www.ad.nl/binnenland/aantalcoronapatienten-groeit-wereldwijd-harder-dan-ooit-de-pandemie-is-nog-volopgaande $\sim$ a8b55193/?fbclid=IwAR2WT9guvSA6bCfSSj2hsInDy7YWvHBHJ6CH8sZ3DJZPPPcF c1 getd $1 \mathrm{mhVo \& referrer=https://www.facebook.com/}$

No Borders. (2020, April 12). Pepijn Brandon: Coronavirus and the "survival of the fittest" in the Netherlands. Retrieved from https://nobordersnews.org/2020/04/12/pepijn-brandon-coronavirusand-the-survival-of-the-fittest-in-the-netherlands/?fbclid=IwAR3rJ2IZ5QOOevm39dpDlTHRngxTMvCe6Mu3e4u0tyXSpbUNQxAmYFKygo

NOS. (2020, March 27). Bijna-monopolie van farmaceut Roche leidt tot tekort aan coronatests. Retrieved from https://nos.nl/artikel/2328393-bijna-monopolie-van-farmaceut-roche-leidt-tot-tekort-aancoronatests.html

NOS. (2020, April 20). Grote pensioenfondsen diep onder water: 77 miljard verdampt. Retrieved from https://nos.nl/artikel/2331159-grote-pensioenfondsen-diep-onder-water-77-miljard-verdampt.html

NOS. (2020, April 24). Hoogleraar staatsrecht: noodverordening gaat nu veel te ver. Retrieved from https://nos.nl/artikel/2331563-hoogleraar-staatsrecht-noodverordening-gaat-nu-veel-te-ver.html

NOS. (2020, May 10). Zo leeft het complotdenken in Nederland. Retrieved from https://www.facebook.com/nos/videos/948723972225068/UzpfSTE1OTQ0NDI3NDU6MTAyMj A4ODU5NDYwOTA0NzM/

NRC. (2020, February 14). Coronacrisis kondigt het einde van de globalisering aan. Retrieved from https://www.nrc.nl/nieuws/2020/02/14/coronacrisis-kondigt-het-einde-van-de-globalisering-aana3990509? fbclid=IwAR2fTS9bulQyyGnhaswFDXU2yTORDVKZJ3OnMsTvMIWR6qjCLt6sn1SvAw

NRC. (2020, March 23). Staat perkt burgerlijke vrijheden radicaal in. Retrieved from https://www.nrc.nl/.../staat-perkt-burgerlijke-vrijheden...

NU.nl. (20, April 13). Eurocommissaris waarschuwt lidstaten voor bedrijfsovernames vanuit China. Retrieved from https://www.nu.nl/economie/6044453/eurocommissaris-waarschuwt-lidstatenvoor-bedrijfsovernames-vanuit-china.html?fbclid=IwAR0CN4luJluSyi4EuQR1n1wSrTCWUzjIhM6E_BGcrQPJ7_FrpCR0P-zhZU

NU.nl. (2020, June 5). Bewijs dat zwarte Amerikanen ongelijk behandeld worden is overweldigend. Retrieved from https://www.nu.nl/weekend/6056099/bewijs-dat-zwarte-amerikanen-ongelijkbehandeld-worden-isoverweldigend.html?fbclid=IwAR1tVT0gckO_xSyBluleX2w0qrIqjbMSYBP13Jn9IAPjtfrs0SW HkG_GIJY

NU.nl. (2020, June 11). Utrechtse gemeenteraad: Het is tijd om afscheid te nemen van Zwarte Piet. Retrieved from https://www.nu.nl/utrecht/6056933/utrechtse-gemeenteraad-het-is-tijd-om- 
afscheid-te-nemen-van-zwarte-

piet.html?fbclid=IwAR1RLx7Bpsaogzf7mWzlp0gbd0_rTOzyz1fI_DaAr7f1EPJTEpvZkquAHKo

Osborne, H. (2020, April 20). Coronavirus Outbreak May Have Started As Early As September, Scientists Say. Retrieved from https://www.newsweek.com/coronavirus-outbreak-september-not-wuhan1498566? fbclid=IwAR1Dmwb8WHcPPOK_fPnVTbrrduGlvHQQpBaB-wGtYqlTcAGJYJrHGa2oLs

Panetta, G. (2020, April 12). Pope Francis says it might be 'time to consider a universal basic wage' in Easter letter. Retrieved from https://www.businessinsider.com/pope-francis-it-might-be-time-toconsider-universal-basic-wage-2020-

4 ? utm medium $=$ social\&utm source $=$ facebook.com\&utm campaign=sf-bimain\&fbclid=IwAR3fdl7xt5uaLSBujYOFIB8bYSWuGPvdcSEYOfrTlksG0DDXnVE7JQ40qA4

Perkins, C. (2020, June 18). The end of tourism? Retrieved from https://www.theguardian.com/travel/2020/jun/18/end-of-tourism-coronavirus-pandemic-travelindustry?fbclid=IwAR2Y4Kr79allYpiiLAzXcfxiAtWkVsUAFcWe1pQwdfB5KJiMUx1HCim1zk

Perper, R. (2020, May). US billionaires got $\$ 434$ billion richer during the pandemic, according to report. Retrieved from https://www.businessinsider.com/us-billionaires-434-billion-richer-duringpandemic-report-2020-5?utm_campaign=sf-bi-

main\&utm_source=facebook.com\&utm_medium=social\&fbclid=IwAR0T4CdbY3eovZPYfWDj 1rfuOSp5du311_0Dhg--AN4oZGmUfoMilBv9gms

Phillips, T. (2020, March 23). Brazil's Jair Bolsonaro says coronavirus crisis is a media trick. Retrieved from https://www.theguardian.com/world/2020/mar/23/brazils-jair-bolsonaro-says-coronaviruscrisis-is-a-mediatrick?CMP=fb_gu\&utm_medium=Social\&utm_source=Facebook\&fbclid=IwAR1I094gBi37cD_VOh0IFqnceldquvS6O39fcI0SsDFk0cKbtr0n4fDMN4\#Echobox $=1584969318$

Phillips, T. (2020, May 3). 'We are on the eve of a genocide': Brazil urged to save Amazon tribes from Covid-19. Retrieved from https://www.theguardian.com/world/2020/may/03/eve-of-genocidebrazil-urged-save-amazon-tribes-covid-19-sebastiaosalgado?CMP=fb_gu\&utm_medium=Social\&utm_source=Facebook\&fbclid=IwAR33m7XKQXt XTLuS2-_SoE_NSgYkJH9C9QDDinOS_57YHeEzkcQQ484A3JE\#Echobox=158851459

Pinxteren, G.v. (2020, April 19). China wil de 'klus' in Hong Kong. Retrieved from https://www.nrc.nl/nieuws/2020/04/19/china-wil-de-klus-in-hongkong-afmakena3997211?fbclid=IwAR1QoM5_gTpXo042Tg859eXRX899xJ7n7wLnB6VdtsSogMFrzLGCV GUblw

PM News. (2020, February 17). Jehovah's Witness predicted coronavirus 15 years ago. Retrieved from https://www.pmnewsnigeria.com/2020/02/17/awake-jehovah-witness-magazine-predictedcoronavirus-15-years-ago/

Politico Magazine. (2020, March 19). Coronavirus Will Change the World Permanently. Here's How. Retrieved from https://www.politico.com/news/magazine/2020/03/19/coronavirus-effecteconomy-life-society-analysis-covid-135579

Prashad, V. (2020, Mach 27). We won't go back to normal, because normal was the problem. Retrieved from https://mronline.org/2020/03/27/we-wont-go-back-to-normal-because-normal-was-theproblem/

Pre, R.D. (2020, June 8). Met z'n allen de lucht in? De Kamer wil een protocol. Retrieved from https://www.volkskrant.nl/nieuws-achtergrond/met-z-n-allen-de-lucht-in-de-kamer-wil-eenprotocol $\sim$ b33cb64c/?utm_source $=V K \& u t m \_$medium $=$email\&utm_campaign $=20200608 \% 7$ Cavo nd\&utm_content $=1 \% 2 \mathrm{C} \overline{5}+$ meter + in + bus $\% \overline{2} \mathrm{C}+$ tram + en + metro $\% \overline{2}-$ + maar + niet + in + het + vliegtuig $\% 3 \mathrm{~F}+$ Kamer+

Pueyo, T. (2020). The hammer and the dance; What the next 18 month could look like. Retrieved from https://www.coastsidebuzz.com/coronavirus-the-hammer-and-the-dance-what-the-next-18months-can-look-like/

308 Journal of Applied Business and Economics Vol. 23(3) 2021 
Pueyo, T. (2020, April 20). Coronavirus: Learning How to Dance. Retrieved from https://medium.com/@tomaspueyo/coronavirus-learning-how-to-dance-b8420170203e

Pullella, P. (2020, June 19). The Vatican has urged Catholics to drop investments in fossil fuels and arms. Retrieved from https://www.weforum.org/agenda/2020/06/vatican-catholics-investments-fossilfuels?fbclid=IwAR1qOucBHsaY1R1CUOJNyrHx5oDj2gorbDABEVFa32Dk-1BoU4E2DGBhc9k

Quekel, S. (2020, May 30). Onderzoek toont aan: coronavirus is niét op beruchte vismarkt in Wuhan ontstaan. Retrieved from https://www.ad.nl/dossier-coronavirus/onderzoek-toont-aancoronavirus-is-niet-op-beruchte-vismarkt-in-wuhanontstaan aefc2431/?fbclid=IwAR1GFQQhcTy4bLZanJDJF0psWJPyPj16XFQVk62fFYeKtdOtSsyE-dTZAM

Rabaey, M. (2020, March 23). De VS worden het grote rampgebied, dat wordt hartbrekend. Retrieved from https://www.topics.be/-de-vs-worden-het-grote-rampgebied-dat-wordt-hartbrekenda14199880demorgen/44ec2dd8a992c3d03c6cd084cd355fa91a50a20abe69448d290472c478ce075 $1 /$ ?context $=$ brand $/ \mathrm{dm} / \&$ referrerUserId $=2 \mathrm{e} 1 \mathrm{ca} 6 \mathrm{cc}-3 \mathrm{f} 90-4 \mathrm{fac}-87 \mathrm{c} 8-2 \mathrm{e} 7 \mathrm{e} 45 \mathrm{f} 1 \mathrm{c} 446$

Relman, E., \& Haltiwanger, J. (2020, May 29). Trump announces he's 'terminating' the US's relationship with the World Health Organization. Retrieved from https://www.businessinsider.com/trumpsays-hes-terminating-us-relationship-with-world-health-organization-20205?utm_source=facebook.com\&utm_medium =social\&utm_campaign=sf-bimain\&fbclid=IwAR2GaVeVy1-HbtjjO7iMHeguaX-wsHu1tbSqDSwlwpeENubLieeQeXffc4w

Ries, B., \& Wagner, M. (2020, April 14). Universities begin considering canceling in-person classes until 2021. Retrieved from https://edition.cnn.com/2020/04/14/us/university-may-cancel-classes-fall2021-trnd/index.html?utm medium $=$ social\&utm content $=2020-04$ -

$14 \mathrm{~T} 20 \% 3 \mathrm{~A} 00 \% 3 \mathrm{~A} 35 \& \mathrm{utm}$ term=link\&utm source=fbCNN\&fbclid=IwAR11NYv4kOvkmADLQRIrziAfRiHvrnFPLNbMRPBgA6GAuS9g4kVJLAa670\&fbclid=

Rockeman, O., \& Ward, J. (2020, June 14). Millions of Job Losses Are at Risk of Becoming Permanent. Retrieved from https:/www.bloomberg.com/news/articles/2020-06-14/millions-of-jobs-could-bepermanently-lost-in-reallocation-

shock?srnd=premium\&utm_source=facebook\&utm_medium=social\&utm_campaign=socialfloworganic\&utm_content $=$ business\&cmpid $=$ socialflow-facebook-business $\&$

Rosman, C., van Assen, M., \& van Zon, H. (2020, April 17). Zo ziet Nederland eruit in 2022, volgens zeven deskundigen. Retrieved from https://www.ad.nl/binnenland/zo-ziet-nederland-eruit-in2022-volgens-zeven-deskundigen a7225db8/?fbclid=IwAR1bn7vUYIPyAz9mRW9aLUsoWkykTP_W8tmenegjbDf6KxkGSgI4tOg5U

Routley, N. (2020, June 3). 6 charts that show what employers and employees really think about remote working. Retrieved from https://www.weforum.org/agenda/2020/06/coronavirus-covid19-remoteworking-office-employeesemployers?fbclid=IwAR2Y501ugUuU5qnJ9IlgWr7cpHn5I8JL5IQRLgazhD6KGDrIQ5eo0ozob uW

rtl nieuws. (2020, March 31). Zittende leiders profiteren van coronacrisis. Retrieved from https://www.rtlnieuws.nl/nieuws/buitenland/artikel/5076446/corona-peilingen-leiders-profiterencrisis?fbclid=IwAR2nGNKDI6rpLpdXumkchZyZs60Fx34JT9zRhmIx8StLS87ZTnfcyrESLsY

rtl nieuws. (2020, April 24). Weg met de schutting: betere buren door coronacrisis. Retrieved from https://www.rtlnieuws.n1/editienl/artikel/5101446/burendag-vriendschap-buren-beter-lerenkennen-coronacrisis-covid-19?fbclid=IwAR3tcJH5dMdFvuqMIUe1 fTZmsEBZZbDjX7xuKADRDNJHTJmjJva2301RcE

Ryan, T. (2020, May 6). Lockdown: It's not about how we get out, it's about how we stay out. Retrieved from https://www.irishtimes.com/opinion/lockdown-it-s-not-about-how-we-get-out-it-s-abouthow-we-stay-out-1.4245488

Saiidi, U. (2020, March 18). Hong Kong is putting electronic wristbands on arriving passengers to enforce coronavirus quarantine. Retrieved from https://www.cnbc.com/2020/03/18/hong-konguses-electronic-wristbands-to-enforce-coronavirus- 
quarantine.html?fbclid=IwAR12CvhVrp0dhwIULEZ1aJS3ZeqqneA_7nzeLP4bc6_mYXOJDuInFpUjZ0

Sala, E. (2020, May 16). The best way to avoid future pandemics? Protect the natural world. Retrieved from https://www.weforum.org/agenda/2020/05/seychelles-conservation-nature-coronaviruspandemics?fbclid=IwAR1VMBWM8D04B60LEABsMBzxbTpuREIN1CWVfCMHNeaWnZhhvLX-8inbfk

Sandler, R. (2020, May 11). Google Will Let Employees Work From Home Until The End Of 2020. Retrieved from https://www.forbes.com/sites/rachelsandler/2020/05/08/google-will-letemployees-work-from-home-until-the-end-of2020/?fbclid=IwAR38y2xZZ0wm5yWrR6ft3oMJcwesQ_WkhVWzhU01zFbiPgBcHJSWGS6aP JU\#62b1f0c27db3

Scheidel, W. (2017, February 21). The Only Thing, Historically, That's Curbed Inequality: Catastrophe. Retrieved from https://www.theatlantic.com/business/archive/2017/02/scheidel-great-levelerinequalityviolence/517164/?fbclid=IwAR0hHHOo9ogibKmIBYwLK4126RLvX1AyjdbTAI82ZeZB2UtO2 u9YJwi4OjU

Schwab, K., \& Vanham, G. (2020, April 13). What we must do to prevent a global COVID-19 depression. Retrieved from https://www.weforum.org/agenda/2020/04/covid-19-how-to-prevent-a-globaldepression?fbclid=IwAR0OPhU2wv1loIFm-xcVprZyJEtQpCgY3il781w0HdobuoY195nHEyvbEs

Schwartzel, E., Sider, A., \& Haddon, H. (2020, April 13). The Coronavirus Economic Reopening Will Be Fragile, Partial and Slow. Retrieved from https://www.wsj.com/articles/the-coronaviruseconomic-reopening-will-be-fragile-partial-and-slow11586800447?fbclid=IwAR2FBWaOUY76Brx7klWftyqVizyqmBoETFbBeW86mvHsHflsy6ux5aVJso

Shilling, G. (2020, March 20). A Look at Economies and Markets After Covid-19. Retrieved from https://www.bloomberg.com/opinion/articles/2020-03-20/coronavirus-a-long-term-look-ateconomies-and-markets?utm_medium $=$ social\&utm_campaign $=$ socialfloworganic\&cmpid=socialflow-facebookbusiness\&utm_source=facebook\&utm_content=business\&fbclid=IwAR2yAGPc6onv

ShutDownDC. (2020, April 15). OK, we did it. Retrieved from https://www.shutdowndc.org/press?fbclid=IwAR2BXV4EAMgvZH1IkGM6cWTiibtkZKqKCae LS58BXWBMFPy_hA18jPUy35U

Siret, M. (2020, May 3). Coronavirus: What global travel may look like ahead of a vaccine. Retrieved from https://discoversociety.org/2020/04/06/covid-19-and-the-impact-of-racial-capitalism-in-thecaribbean/?fbclid=IwAR3fsF2hLapY4nCqlGHkeceYiseQ6cSwlIXGjTYHkVtTWkYCkRjwa9Pqo4

Slagmeulder, T.D., \& de Slagmeulder, T. (2020, April 25). Disneyparken wereldwijd waarschijnlijk pas in 2021 weer open. Retrieved from https://www.ad.nl/buitenland/disneyparken-wereldwijdwaarschijnlijk-pas-in-2021-weer-open a9c59487/?fbclid=IwAR0r_VVw2RWrvtZuNdWVfE_Scldx246h81HL68pvG0bN6D7gQRrhOaQsP4\&referrer=https://www.facebook.co $\mathrm{m} /$

Smith, L. (2020, April 27). Flying after COVID-19 will never be the same. Here's what airplane seats could look like. Retrieved from https://www.fastcompany.com/90496843/flying-after-covid-19will-never-be-the-same-heres-what-airplane-seats-could-looklike?fbclid=IwAR1 ykfhGf0awxgMhpIZuLKMX5E4oNzZOdLTnVUHDQ4eYtErcRCJo_ERefFs

Smithers, R. (2020, May 17). Restaurant-grade gourmet potatoes go on sale in Tesco to ease glut. Retrieved from https://www.theguardian.com/business/2020/may/17/restaurant-grade-gourmetpotatoes-go-on-sale-in-tesco-to-easeglut?CMP=fb_gu\&utm_medium $=$ Social\&utm_source $=$ Facebook\&fbclid $=$ IwAR3NRdByNgvH8t hhK6JVV1XrVnP7RXMjaQHhMnHqxOmYJSh0gNfQ7qzGEBQ\#Echobox=1589724551 
Smoltczyk, A. (2020, April 9). How Lisbon Has Managed the Corona Crisis. Retrieved from https://www.spiegel.de/international/europe/portugal-how-lisbon-has-managed-the-corona-crisisa-b6e3c7ba-a172-4c11-a04379849ff69def?fbclid=IwAR08SPju_YhTX1MQ9r1BB6J6ZiEbGQXFmDgr7n0A27ZmsaAWeGKK3loBBM

Sneader, K., \& Singhal, K. (2020, March). Beyond coronavirus: The path to the next normal. Retrieved from https://www.mckinsey.com/industries/healthcare-systems-and-services/our-insights/beyondcoronavirus-the-path-to-the-next-normal

Sneader, K., \& Singhal, S. (2020, March). Beyond coronavirus: The path to the next normal. Retrieved from https://www.mckinsey.com/industries/healthcare-systems-and-services/our-insights/beyondcoronavirus-the-path-to-the-next-normal?cid=soc-app\&fbclid=IwAR16P7UA4OFyAkW528TUyjqAAG1fHTuzog1 gm1 rts3fwQ813TIhRN1CesQ

Snouwaert, J. (2020, May 26). 3-day weekends are better': Andrew Yang says the US should 'seriously' consider switching to a 4-day workweek to boost people's mental health. Retrieved from https://www.businessinsider.com/andrew-yang-4-day-workweek-longer-weekend-improvesmental-health-2020-5?utm_medium=social\&utm_campaign=sf-bimain\&utm_source=facebook.com\&fbclid=IwAR3zVhHp5QwTgZjFqH3Nc4UONQX2LsCafegqN0j654M_AbYEN8MXNuOSBU

Soudagar, R. (2020, April 24). HOE WE IN CRISIS ALTIJD 'DE ANDER' DE SCHULD GEVEN. Retrieved from https://www.oneworld.nl/lezen/discriminatie/racisme/hoe-we-in-crisis-altijd-deander-de-schuldgeven/?utm_content=buffere05b9\&utm_medium=social\&utm_source=facebook\&utm_campaign $=$ buffer\&fbclid=IwAR0a4JV-cAGzCk4NDHrZ9uV88D_VSkdVTIE4BSYyHqHq34itV443RtAwdo

Spahn, J. (2020, May 23). How Germany contained the coronavirus. Retrieved from https://www.weforum.org/agenda/2020/05/how-germany-contained-thecoronavirus?fbclid=IwAR34m9VSUh_Oc_ZJdMD9wc_TQFnWvJ5KJcT97wK99RTcquPDeR32 kNvJAMI

Sparrow, A. (2020, March 23). UK coronavirus: Boris Johnson announces strict lockdown across country - live. Retrieved from https://www.theguardian.com/politics/live/2020/mar/23/uk-coronaviruslive-news-latest-boris-johnson-minister-condemns-people-ignoring-two-metre-distance-rule-inparks-as-veryselfish?CMP=fb_gu\&utm_medium=Social\&utm_source=Facebook\&fbclid=IwAR3FG5DaoBLS y3o

Spinney, L. (2020, April 12). Inequality doesn't just make pandemics worse - it could cause them. Retrieved from https:/www.theguardian.com/commentisfree/2020/apr/12/inequality-pandemiclockdown?fbclid=IwAR2OxoOEwIHr3BD8lwjqzujrnLInI7BiDeUDqgAZ3Y3aXGIS5f8QCY5Br SW

Stellino, M. (2020, March 21). Fact check: Did the coronavirus originate in a Chinese laboratory? Retrieved from https://www.usatoday.com/story/news/factcheck/2020/03/21/fact-check-didcoronavirus-originate-chineselaboratory/2881150001/?fbclid=IwAR30LffZBPB7T6vUobEtPwcbynWt4DAWzcy7Kze5kgtj0h 5ZwrAs8W93DEQ

Stewart, H. (2020, May 13). Beneath the mixed messages, the Tories are putting wealth ahead of wellbeing. Retrieved from https://www.theguardian.com/world/2020/may/13/mixed-messagestories-wealth-ahead-wellbeingcoronavirus? $\mathrm{CMP}=\mathrm{fb} \_$gu\&utm_medium $=$Social\&utm_source $=$Facebook\&fbclid $=$IwAR2YkhZy K83f3PmwetknmOjyoePIowRgdi3woxjzy4CDr-ZpVMWEXTmXebc\#Echobox=1589400143

Stoffelen, A. (2020, March 20). Voor de vaak vergeten schoonmaker klinkt in de coronacrisis eindelijk applaus. Retrieved from https://www.volkskrant.nl/nieuws-achtergrond/voor-de-vaak-vergeten- 
schoonmaker-klinkt-in-de-coronacrisis-eindelijk-applaus $\sim$ b9d38028/?fbclid=IwAR2bsO0GA7kk0E11BuClz1yetNdGDC1DpRS5g9nKKeHVWX2k-fB6OXzMqE

Stone, P. (2020, May 3). Trump's wealthy friends look to cash in during coronavirus crisis. Retrieved from https://www.theguardian.com/us-news/2020/may/03/trump-coronavirus-wealthy-friendsdonors-backers?CMP $=\mathrm{fb} \_$gu\&utm_medium $=$Social\&utm_source $=$Facebook\&fbclid=IwAR3FqnPFgBvu6RwOutDc2_q_ipf-8t57PEPj5VRF7GakZRd_7HVPwXbpac\#Echobox=1588519229

Sutton, H.I. (2020, May 24). Tracking The 5 Iranian Oil Tankers Heading To Venezuela. Retrieved from https://www.forbes.com/sites/hisutton/2020/05/24/tracking-the-5-iranian-oil-tankers-heading-tovenezuela/?fbclid=IwAR2vwmfr4-aRSdx3ZMSPCvxLf5KQXAM2TQPc8IvZduWFMS6JtzWMRmNN24\#2aa0db5d4761

Telegraph Reporters. (2020, April 17). No evidence that people who have survived coronavirus have immunity, says World Health Organisation. Retrieved from https://www.telegraph.co.uk/news/2020/04/17/no-evidence-people-have-survived-coronavirushave-immunity-

says/?utm_content=telegraph\&utm_medium $=$ Social\&utm_campaign $=$ Echobox\&utm_source=Fac ebook\&fbclid=IwAR0enIiUbk7MKxnEmp5OS-CJYiLFno4aMZ7Z--D2_fT0qMg4dt14aoEo

Telesur. (2020, March 20). Chomsky y Coronavirus Covid19. Retrieved from https://www.youtube.com/watch?v=jxXgBMqdGxc\&feature=share\&fbclid=IwAR1Wu9hpFnzih 7SHN2a5uQxw5jpGabpwxLC9qmzAmHHqJgXZn1p_R1IIL6A

The Economic Times. (2020, March 19). Is COVID-19 A Bioweapon? Five Conspiracy Theories Around Coronavirus That Will Shock You. Retrieved from https://economictimes.indiatimes.com/magazines/panache/is-covid-19-a-bioweapon-fiveconspiracy-theories-around-coronavirus-that-will-shock-you/a-pandemic-that-sentshockwaves/slideshow/74388518.cms?fbclid=IwAR2y17FZxjjPNt_CyNXya3weOPHnsrfYhCNmxirXjOu0RyO

The Economist. (2020, June 17). India and China have their first deadly clashes in 45 years. Retrieved from https://www.economist.com/asia/2020/06/18/india-and-china-have-their-first-deadlyclashes-in-45-years

The Hope Man. (2020, April 19). Massive protest in India "THE AWAKENING". Retrieved from https://www.youtube.com/watch? $\mathrm{v}=\mathrm{gZdY15WkTMQ \& feature=}=$ hare \&fbclid=IwAR0L6Mn3Clu K3STEPIIFaRzoJgmDn0HwtkYsMhkEa5ci_iDhx2Se9bFizcY

The Mind Unleashed. (2020, April 27). America's Super-Rich See Their Wealth Rise by \$282 Billion in Three Weeks of Pandemic. Retrieved from https://themindunleashed.com/2020/04/america-superrich-see-their-wealth-rise-by-282-billion-in-three-weeks-ofpandemic.html?fbclid=IwAR1 Idj6N7MqlpubWSjSV3N6dMmGTBcsj2zAk6PYBePQy$53 \mathrm{qkULaO} 1 \mathrm{smBFM}$

The Rockefeller Foundation. (2010). Scenarios for the Future of Technology and International Development. The Rockefeller Foundation and Global Business Network.

Tian, Y.L. (2020, May 26). China's Xi urges preparedness for military combat amid coronavirus epidemic: state TV. Retrieved from https:/www.reuters.com/article/us-china-parliament-xiidUSKBN2321IL?utm_campaign=trueAnthem $\% 3 \mathrm{~A}+$ Trending + Content\&utm_medium $=$ trueAnth em\&utm_source=facebook\&fbclid=IwAR3Vf68rmrtOiGvz1qZUCglPYdvgTQkZ6XB6SIrC8DA cLH3rIvq9LidASlw

Toh, M. (2020, May 20). World Bank: Pandemic could force 60 million more people to live on less than $\$ 2$ a day. Retrieved from https://edition.cnn.com/2020/05/20/economy/world-bank-povertycoronavirus-intl-hnk-scli/index.html?utm_medium=social\&utm_term=link\&utm_content $=2020$ 05-20T13\%3A59\%3A03\&utm_source $=\mathrm{fbCNN \& fbclid=IwAR1-}$ E0oV_Gz_ipHoKvt0h2EljYNOCWCJiyte2bSyQbLQ1JXV-U0_mq1dRnQ

Toynbee, P. (2020, April 20). Boris Johnson is the wrong man in the wrong job at the wrong time. Retrieved from https://www.theguardian.com/commentisfree/2020/apr/20/boris-johnson-sundaytimes-prime-minister- 
coronavirus?CMP $=\mathrm{fb}$ gu\&utm_medium $=$ Social\&utm_source $=$ Facebook\&fbclid $=$ IwAR0brFzN Xr5b4fBS9Tb4AGuMWWVYC̄7MBx11rssVFaCG7UYPkSv4zgwpW3g\#Echobox=1587391114

Tozzi, J. (2020, April 14). Harvard Researchers Say Some Social Distancing May Be Needed Into 2022.

Retrieved from https:/www.bloomberg.com/news/articles/2020-04-14/harvard-researchers-saysome-distancing-may-be-needed-into-

2022?utm_source $=$ facebook\&utm_medium $=$ cpc\&utm_campaign $=496114$ USAll\&kwp_0 $=1630$

751\&fbclid=IwAR0nOvaRIQq_0cDhKkZRCgFoIxyo-VRgwQU83iLqa-CJf4EYKTWS2yL_Q

van de Wiel, C. (2020, May 27). Brussel komt met herstelfonds van 750 miljard euro. Retrieved from https://www.nrc.nl/nieuws/2020/05/27/brussel-presenteert-herstelfonds-van-750-miljard-euroa4000928?utm source=social\&utm medium=facebook\&utm campaign=facebook\&utm term=2 0200527\&fbclid=IwAR0QaFx6rYE4Xj91u1Afy6pCNsy69F_OLr_8p5hLCRaJGsNsyqPNy3mv9 $2 \mathrm{~g}$

van der Tuin, I. (2020, April 4). Past-Present-Future and the 2019-20 Coronavirus Pandemic. Retrieved from https://identitiesjournal.edu.mk/index.php/IJPGC/announcement/view/23

van Hoof, E. (2020, April 9). Lockdown is the world's biggest psychological experiment - and we will pay the price. Retrieved from https://www.weforum.org/agenda/2020/04/this-is-the-psychologicalside-of-the-covid-19-pandemic-that-wereignoring?fbclid=IwAR0OFOZWaQBKiirKWZ3qH18hlDBOVbMioU3_UfnZHkxFCwzr1RQ2puJxCs

van Houwelingen, K. (2020, April 28). Ic-arts in New York: 'Als je geen geld hebt, ben je hier de pineut'. Retrieved from https://www.parool.nl/wereld/ic-arts-in-new-york-als-je-geen-geld-hebt-ben-jehier-de-pineut $\sim$ b64d96aa/?fbclid=IwAR0ML0v-

ufjCKLufJPqo1ZJYIPKteSoAS_Rcyt7xBx7h630WufKJP5aXjQg\&referer=https\%3A\%2F\%2Fw ww.facebook.com $\% 2 \mathrm{~F}$

van Noort, W. (2020, April 27). Ian Bremmer: "De grote vraag is of corona leidt tot een nieuwe Koude Oorlog". Retrieved from https://www.nrc.n1/nieuws/2020/04/27/de-grote-vraag-is-of-coronaleidt-tot-een-nieuwe-koude-oorlog-a3998031

van Pykeren, S. (2020, April 13). These Photos Show the Staggering Food Bank Lines Across America. MotherJones. Retrieved from https://www.motherjones.com/food/2020/04/these-photos-showthe-staggering-food-bank-lines-across-

america/?fbclid=IwAR1ESwCrZvThd6K7c53WLSq2DQiXphU0SnjDh_G1O1GPFhmxb4QFbTa R6Jk

van Raaij, B. (2020, May 15). Onze cultuur neemt veel meer dan ze teruggeeft. Retrieved from https://www.volkskrant.nl/mensen/onze-cultuur-neemt-veel-meer-dan-zeteruggeeft $\sim \mathrm{b} 3 \mathrm{a} 2 \mathrm{e} 18 \mathrm{c} /$ ?fbclid=IwAR0XvZzcrS4Kf5C4trueLZogGvMmFmjrdLpggAbZ8cAD_7P9P3r4sGaGtc

Venhuizen, G. (2020, June 12). Wat maakt dat sommige mensen tijdens deze crisis zelfs beter gedijen dan normaal? Retrieved from https://www.nrc.nl/nieuws/2020/06/12/we-zitten-in-een-grootpsychisch-experimenta4002618?utm_source $=$ social\&utm_medium $=$ facebook\&utm_campaign=facebook\&utm_term $=2$

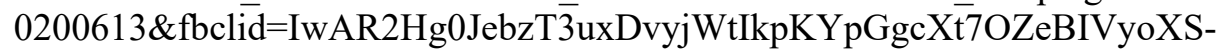
P0iFHHUDety_JvtM

Villarreal, D. (2020, May 5). DR. FAUCI DISMISSES WUHAN LAB AS SOURCE OF CORONAVIRUS, CONTRADICTING TRUMP AND POMPEO. Retrieved from https://www.newsweek.com/drfauci-dismisses-wuhan-lab-source-coronavirus-contradicting-trump-pompeo1501924?fbclid=IwAR0BY0rGtiHNI3oaRDPe9JZNEssRJKwcmZwgcA4LqnFs4CPT508Zhj6Jh 54

Voegele, J. (2020, April 21). CORONAVIRUS: WHAT IS THE IMPACT OF THE CRISIS ON GLOBAL FOOD SECURITY? Retrieved from https://live.worldbank.org/coronavirus-what-impact-crisisglobal-food- 
security?CID=ECR_FB_worldbank_EN_EXT\&fbclid=IwAR3yMnamLcqKtcS8WxaKEwE2Sm wmvB2GTm6taqYRode4ThuivZIY 0nWwok

VPRO. (2020, May 10). Duurzaam: nu of nooit. Retrieved from https://www.facebook.com/vprotegenlicht/videos/572156536741643/UzpfSTE1OTQ0NDI3NDU 6MTAyMjA4NzUyNjE1NDMzNjY/

Walgien, N. (2020, April 2). 9 voorstellen voor een betere wereld na corona. Retrieved from https://www.vpro.nl/programmas/tegenlicht/lees/artikelen/2020/9-voorstellen-betere-wereldcorona.html?fbclid=IwAR2kzxLu7Apv7K1sSQYX8kSsZQckkweteEpGqVDHompT67iS7OnWNLagY4

Wallace-Wells, D. (2020, April 27). In Conversation: Thomas Piketty The scholar of inequality warned us that our economic systems couldn't withstand a global catastrophe. Retrieved from https://nymag.com/intelligencer/2020/04/thomas-piketty-capital-and-ideology-coronavirusinequality.html?utm_source=fb\&fbclid=IwAR21weLDAVD1OmEDGw3NVcByHUQfN9KyQE FWfb3xEDqWo5XFy2pL-TW0wwk

Walt, S.M. (2020, May 13). Will a Global Depression Trigger Another World War? Retrieved from https://foreignpolicy.com/2020/05/13/coronavirus-pandemic-depression-economy-worldwar/?fbclid=IwAR0B4ieMLE_suLtjI_yTjouPweguQdE2MoQ7fKsv66YmNCRicNKS1rMrSpA

Watts, J. (2020, May 5). One billion people will live in insufferable heat within 50 years - study.

Retrieved from https://www.theguardian.com/environment/2020/may/05/one-billion-people-willlive-in-insufferable-heat-within-50-years-

study?CMP=fb_gu\&utm_medium=Social\&utm_source=Facebook\&fbclid=IwAR2KMlIPcEpGQ CyeUYHsOQv_PnxpoT-qr8IUoGB_QOrJ_JQA_n6k1gO1rTI\#Echobox=158866

Westcott, B. (2020, May 27). Australia angered China by calling for a coronavirus investigation. Now Beijing is targeting its exports. Retrieved from https://edition.cnn.com/2020/05/26/business/china-australia-coronavirus-trade-war-intl$\mathrm{hnk} /$ index.html?utm_source $=\mathrm{fbCNNi \& utm \_ content}=2020-05$ $27 \mathrm{~T} 06 \% 3 \mathrm{~A} 01 \% 3 \mathrm{~A} 04 \& u t m \_$term $=$link\&utm_medium $=$social\&fbclid=IwAR2SCgkdQcNB9C_jQ 1PCiEDRKj4CtAQD84zywLjO-x4FnqRpxLIbalPXoa

Whiting, K. (2020, June 3). How the world can 'reset' itself after COVID-19-according to these experts. Retrieved from https://www.weforum.org/agenda/2020/06/covid19-great-reset-gita-gopinathjennifer-morgan-sharan-burrow-climate?fbclid=IwAR3kaj9SVTBwhBYTregvrlxDHXcDKrCqaAZ9XPUggzgNWyxWYlP_JkJkgU

Wilson, A. (2020, April 2). The Countries That Are Succeeding at Flattening the Curve. Retrieved from https://foreignpolicy.com/2020/04/02/countries-succeeding-flattening-curve-coronavirus-testingquarantine/?fbclid=IwAR39jDb3c0sRZgbZ5Rg0uDrkQ6LijUiT3XUv9k7W3JwTwoNgF9bYJU VgMA0

Winck, B. (2020, April 20). 'We don't think this is the end of it': Goldman Sachs' commodities expert explains why oil market chaos can continue into mid-May. Retrieved from https://markets.businessinsider.com/commodities/news/oil-wti-price-chaos-continue-maygoldman-sachs-commodity-market-2020-4-1029109105

Winterman, P. (2020, June 15). Bedrijven misbruiken coronasubsidie: 'Steungeld nog zelfde dag vergokt'. Retrieved from https://www.ad.nl/binnenland/bedrijven-misbruiken-coronasubsidie-steungeldnog-zelfde-dagvergokt a7b9b141/?fbclid=IwAR2zVq7wjPfP_mo3qsN1g4GqRLgH6SozRK7Bk_YomUc1KTG 0WgsbV1MecYY\&referrer=https://www.facebook.com/

Wiseman, P., \& Crutsinger, M. (2020, April 14). IMF: Coronavirus effect will drive global economy to worst year since Great Depression. Retrieved from https://www.usatoday.com/story/money/2020/04/14/imf-pandemic-make-2020-worst-worldeconomy-since-great-depression/2987934001/?fbclid=IwAR2TGLZGexhXnNJBcBayCyneG7noOH1ndfc_eaA2Ca74kd7E1pTaXY4nDg 
Wittenberg-Cox, A. (2020, Apeil 14). What Do Countries With The Best Coronavirus Responses Have In Common? Women Leaders. Retrieved from

https:/www.forbes.com/sites/avivahwittenbergcox/2020/04/13/what-do-countries-with-the-bestcoronavirus-reponses-have-in-common-womenleaders/?fbclid=IwAR0EUepsKuM0dEGmuTlfbapm4S1AOyma yd9BYOnCR1KTGdyiRDKa4kz6U\#fe134103dec4

Woodward, A., \& Su, R. (2020, May 5). 3 charts predicting future waves of coronavirus cases show why we should worry about September. Retrieved from https://www.businessinsider.com/secondwave-of-coronavirus-infections-may-peak-in-fall-2020-5?utm_campaign=sf-bimain\&utm_medium=social\&utm_source=facebook.com\&fbclid=IwAR1bgEKa8idwQ4iJQCd8fz 7DBlp6nfJvwmWjAQI-zRihLgzZ̈f9Lh-jTiBMQ

World Bank. (2020, June 12). COVID-19 could push 100 million people into extreme poverty, says World Bank. Retrieved from https://www.weforum.org/agenda/2020/06/world-bank-coronaviruscovid19-extreme-poverty? fbclid=IwAR0vVo37HiytJhlUb_FwLCqIQMpEho2qgbFJt9hKUvIJU_yvtNCzBf_GwQ

World Economic Forum. (2020, April 10). Forest loss could make diseases like COVID-19 more likely, according to study. Stanford University. Retrieved from https://www.weforum.org/agenda/2020/04/forest-loss-diseases-covid19-coronavirusdeforestationhealth?fbclid=IwAR13megjwZ_cjiDDUOtEbUP9sqJJkRKoAWf6b8MEwMXcQEDmeAfaoFDzM

YouTube. (2020, March 27). The speech that is moving the world. El Salvador president, Nayib Bukele on coronavirus pandemic. Retrieved from https://www.youtube.com/watch? $\mathrm{v}=\mathrm{hENCbnBmJwE:}$ https://www.youtube.com/watch? $\mathrm{v}=\mathrm{hENCbnBmJwE}$

Yu, H. (2020, April 20). Commentary: How Zoom-working will change companies forever. Retrieved from https://www.channelnewsasia.com/news/commentary/zoom-remote-working-changecompanies-forever-digital-transform12651864?cid=FBcna\&fbclid=IwAR1GQqhuefHJqNa79yeOq2fzaiWVAfX6tmGpuph5WC10av Dvk8EwUHLrD-g

Zeeuw, E.d. (2020, May 16). Hongerpandemie dreigt: 'Niet corona zelf, maar gevolgen maken meeste slachtoffers'. Retrieved from https://nos.nl/artikel/2334114-hongerpandemie-dreigt-niet-coronazelf-maar-gevolgen-maken-meeste-slachtoffers.html 